\title{
Maestros, hegemonía y contradiscurso
}

Sandra Soler Castillo

Pedro Baquero Másmela 


\section{Maestros, hegemonía y contradiscurso}

Sandra Soler Castillo

Pedro Baquero Másmela
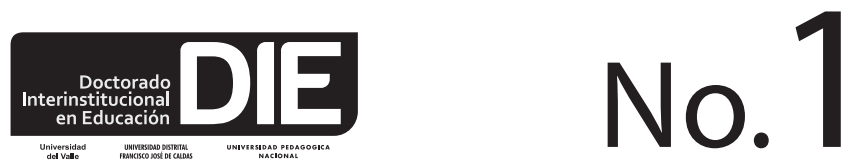


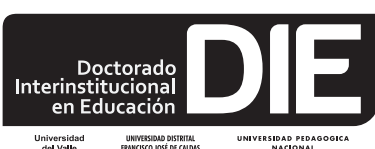

Universidad
del Valle

Comité Editorial Interinstitucional-CAIDE

Carlos Javier Mosquera Suárez

Director nacional

Germán Vargas Guillén

Coordinador DIE,

Universidad Pedagógica Nacional

Sandra Soler Castillo

Directora DIE,

Universidad Distrital Francisco José de Caldas

\author{
Jaime Humberto Leiva \\ Coordinador DIE, \\ Universidad del Valle
}

\section{Comité Editorial CADE}

Sandra Soler Castillo

Presidenta CADE

Álvaro García Martínez

Representante grupos de investigación Interculturalidad, Ciencia y Tecnología-INTERCITEC, y del Grupo Didáctica de la Química-DIDAQUIM, del Énfasis de Educación en Ciencias.

Sandra Soler Castillo

Representante de los grupos de investigación Identidad, Lenguaje y Cultura, Moralia, Estudios del Discurso, Educación Comunicación y Cultura del Énfasis de Lenguaje y Educación.

Olga Lucía León Corredor

Representante de los grupos de investigación Interdisciplinaria en Pedagogía de Lenguaje y las Matemáticas GIIPLyM, Matemáticas Escolares Universidad Distrital-MESCUD, del Énfasis de Educación Matemática.

Rigoberto Castillo Representante de los grupos de investigación Formación de Educadores, del énfasis de Historia de la Educación, Pedagogía y Educación Comparada.
UNIVERSIDAD DISTRITAL

FRANCISCO JOSÉ DE CALDAS

\section{Roberto Vergara Portela}

Rector (E)

Universidad Distrital Francisco José de

Caldas

Boris Bustamante Bohórquez

Vicerrector Académico

Universidad Distrital Francisco José de

Caldas

ISBN impreso: 978-958-8832-23-4

ISBN digital: 978-958-8832-29-6

Primera edición, 2014

(C) U. Distrital Francisco José de Caldas

\section{Preparación Editorial}

Doctorado Interinstitucional en Educación Sede U. Distrital Francisco José de Caldas http://die.udistrital.edu.co

\section{Elban Gerardo Roa Díaz}

Asistente Editorial

eventosdie@udistrital.edu.co

\section{Fondo de publicaciones}

U. Distrital Francisco José de Caldas

Cra. 19 No. 33-39. Piso 2.

PBX: (57+1) 3238400, ext. 6203

publicaciones@udistrital.edu.co

Corrección de estilo

\section{Luisa Juliana Avella Vargas}

Impreso en Javegraf

Bogotá, Colombia, 2014

Prohibida la reproducción total o parcial de la presente obra por cualquier medio sin permiso escrito de la Universidad Distrital Francisco José de Caldas. 


\section{Maestros, hegemonía y contradiscurso}

Sandra Soler Castillo

Pedro Baquero Másmela 


\section{Tabla de contenido}

Maestros y hegemonía. Análisis de titulares del diario El Tiempo: 1977-2005

Introducción

$\begin{array}{ll}\text { 1.Horizonte conceptual } & 15\end{array}$

$\begin{array}{ll}\text { 1.1 Los estudios críticos del discurso } & 15\end{array}$

$\begin{array}{ll}1.2 \text { El problema de la ideología } & 17\end{array}$

$\begin{array}{ll}\text { 2.Metodología } & 24\end{array}$

Delimitación y manejo del corpus 26

3.Análisis $\quad 28$

3.1 Construcción de la agenda temática del diario El Tiempo 29

3.1.1 Huelgas, paros y ceses laborales 30

3.1.2 Aspectos judiciales 33

3.1.3 Salarios de los maestros 36

3.1.4 «Maestros, ja estudiar!» (AA.10). Actividades académicas

3.1.5 Leyes, estatutos y reglamentos 39

3.1.6 «Gobierno condecora a educadores» (RC1). Reconocimientos 40

3.1 .7 «Un burro se come nómina de maestros» (CU3).
Curiosidades y otros asuntos

3.1.8 «Entregan viviendas a maestros» (BS4).

$\begin{array}{ll}\text { Programas de bienestar social para docentes } & 41\end{array}$

3.2 Los actores de la agenda periodística educativa:

maestros, representantes del Estado y agremiaciones de maestros 41

3.2.1 Los maestros 42

3.2.2 Los actores oficiales: políticos y administradores de la educación $\quad 44$

3.2.3 Los colectivos de maestros: FECODE Y ADE. 46

3.3 La ubicación de la noticia en el diario 47

A manera de conclusiones $\quad 50$

Apéndice lingüístico $\quad 55$ 
Contradiscurso y hegemonía en las representaciones del maestro en Colombia

1. Sobre el concepto de contradiscurso 119

2. El maestro: un discurso de otros discursos $\quad 121$

2.1 De apóstol a funcionario 122

2.2 Entre el artesano y el técnico 126

$\begin{array}{ll}2.3 \text { Asalariados e intelectuales } & 129\end{array}$

3. El contradiscurso en la revista Educación y cultura 133

3.1 Sobre el procedimiento metodológico 133

3.2 Análisis y discusión 136

A manera de conclusiones $\quad 159$

$\begin{array}{ll}\text { Referencias } & 161\end{array}$ 


\section{Índice de gráficos}

Gráfica 1. Frecuencia de las temáticas aparecidas en el diario El Tiempo

Gráfica 2. Asesinatos de docentes 2000-2008, según FECODE 34

Gráfica 3. Frecuencia de aparición de actores sociales 42

Gráfica 4. Frecuencia de noticias de maestros en El Tiempo 53

Gráfica 5. Temáticas en la revista Educación y Cultura

\section{Índice de cuadros}

Cuadro 1. Estructuras variables del discurso

Cuadro 2. Estrategias discursivas de la prensa

23

Cuadro 3. Políticas educativas

135

Cuadro 4. Movimiento pedagógico

135

Cuadro 5. Representaciones del maestro 


\section{Presentación}

Maestros, hegemonía y contradiscurso es el título con el que los investigadores Sandra Soler y Pedro Baquero - del grupo de investigación interinstitucional Estudios del Discurso- recogen, en este libro, el fruto de dos investigaciones ${ }^{1}$ realizadas en torno a la figura y representaciones del maestro del sector público en Colombia.

Las investigaciones, estrechamente vinculadas por su campo temático y línea de investigación, situadas justamente en los estudios del discurso y la educación, difieren, sin embargo, en cuanto a los objetos de estudio y a las perspectivas analíticas que se eligen para abordar la pregunta por las representaciones del maestro y su movilización en la producción discursiva de actores sociales específicos, como los medios de comunicación y el propio gremio de maestros. Mientras la primera investigación se ocupa del estudio de las representaciones del maestro y sus acciones en los medios de comunicación con el fin de «desenmascarar las representaciones sociales que cristaliza el discurso mediático, y a partir de las cuales los intérpreteslectores construyen sentido(s)», la segunda, se centra en desarrollar y aplicar el concepto de contradiscurso (Angenot, 1989, 1998, 2010) al análisis de las propias elaboraciones discursivas de los maestros, desde las cuales han resistido y/o legitimado el discurso oficial hegemónico sobre ellos mismos como actores sociales.

1 Este trabajo hace parte del macroproyecto de investigación Las representaciones sociales de los maestros del sector público en Colombia: discurso y contradiscurso. El proyecto se inició a finales del 2009 y concluyó en abril de 2011. 
Podría decirse, en principio, que uno y otro trabajo persiguen finalidades similares en tanto que se ocupan de develar los sentidos que producen o generan los discursos de o sobre dichos actores sociales. Sin embargo, mientras una investigación lo hace desde el discurso de las élites, la otra lo hace desde el discurso de resistencia o contradiscurso producido por los propios maestros como actores sociales subalternizados.

La problemática de la cual parte la primera investigación sitúa al maestro como actor social en el discurso periodístico y apunta al develamiento de las «operaciones y estrategias usadas en el discurso mediático» como agente generador de representaciones sobre la figura del educador y su actuación social. Las herramientas empleadas para el análisis corresponden al aparataje teórico e instrumental del Análisis Crítico del Discurso, ACD (Fairclough, Wodak, Van Dijk), que valiéndose de la deconstrucción de los enunciados lingüísticos y sus mecanismos semánticos, morfosintácticos y retóricos, pone en evidencia las estrategias de funcionamiento discursivo como forma y mecanismo de control simbólico a través del cual un grupo dominante ejerce el poder y el control sobre otros actores sociales en tanto que produce y mantiene, en su propia producción discursiva, relaciones y acciones de desigualdad y dominación.

Por su parte, la segunda investigación procede, desde el análisis de contenido, a desentrañar la manera como ciertas formas de resistencia discursiva actúan de manera recesiva y contribuyen a la sedimentación y naturalización de los discursos hegemónicos, y cuándo, por el contrario, constituyen verdaderas rupturas epistémicas frente a las representaciones dominantes.

Las dos investigaciones confluyen así en la identificación de las representaciones hegemónicas que se movilizan en el entramado social sobre los maestros como actores sociales y hacen visible, en palabras de Angenot, el «implacable monopolio de la representación hegemónica (...) donde lo totalmente divergente sería recuperado, neutralizado, traído a contribuir a la reproducción indefinida de los poderes simbólicos» (1989).

En efecto, la identificación de las estrategias discursivas y sus formas de naturalización en el universo social, promovidas, por ejemplo, en el discurso de élite -manifiesto en la noticia periodística-, pareciera no diferenciarse ni en sus efectos pragmáticos ni en la selección de las estrategias discursivas que emplean para resistirlas los grupos dominados o subalternizados. De esta manera lo que pareciera ser "discurso de la resistencia» en el gremio de los maestros, termina por contribuir a la naturalización y sedimentación de las representaciones hegemónicas discursivas a través de las cuales las élites ejercen poder y control sobre los actores sociales. 
Una y otra investigación se complementan así y señalan una perspectiva sustancialmente crítica que destaca, entre otros aspectos, el papel del discurso en la cognición y cómo en esta se movilizan valores, normas, actitudes e ideologías que constituyen, en últimas, el conocimiento socialmente compartido, cuya producción y distribución es, sin embargo, altamente diferencial, pues las representaciones que se movilizan, vistas como formas de control simbólico, establecen diferencias significativas entre quienes las producen y quienes las apropian y sedimentan. A los primeros los define el poder de decir, basado en una posición diferencial de acceso al discurso público y/o a determinado capital simbólico que actúa como plataforma de poder y control (agencias, agentes y campos de producción discursiva, como las disciplinas científico-sociales, la Iglesia, el Estado y sus agentes, etc.), mientras el segundo grupo actúa como destinatario-receptor de las representaciones y acciones que esos discurso dominantes producen.

En el caso particular de los maestros de que se ocupan ambas investigaciones, los investigadores rastrean en artículos de prensa (EI Tiempo) el discurso de élites sobre dichos actores sociales -para la primera investigación- y en los artículos de la revista gremial Educación y Cultura, el discurso de resistencia o contradiscurso producido por los mismos maestros. El análisis riguroso de estos extensos corpus permite que una y otra investigación hagan visibles no solo las representaciones -quizá suficientemente naturalizadas y sedimentadas- de estos actores sociales sino, sobre todo, los mecanismos discursivos con los que se asegura en la cognición social las condiciones de dominación y control simbólico de los maestros. Así, por ejemplo, se muestran las estrategias de parcialización de la información, deslegitimación de acciones, trivialización, tergiversación, despersonalización, elección de atributos y calificativos, etc., a través de los cuales se promueven imágenes negativas de los maestros y sus acciones con fines de asegurar la deslegitimación de sus demandas, invisibilizar su fuerza como actores sociales o cooptar sus movimientos gremiales.

La construcción de una imagen social negativa de los maestros se muestra, entonces, como producto de estrategias discursivas movilizadas por agentes y agencias de poder que no solo producen y reproducen discursivamente estas imágenes, sino que son capaces también de cooptar y capturar los discursos emergentes surgidos en la resistencia discursiva y de utilizarlos retóricamente como «argumentos públicos para aglutinar voluntades» y hacer creer, entonces, que las demandas que hacen los maestros como actores sociales en conflicto van, o bien contra los principios del orden, la democracia y el buen sentido; o bien que estas demandas ya fueron atendidas y que no existe, por tanto, motivo para continuar «agitando» el orden establecido. 
El efecto de estos discursos en la construcción de representaciones sociales sobre la figura del maestro y sus acciones, así como las formas de producción y reproducción discursiva, los mecanismos de deslizamiento y sedimentación a los que apela el discurso hegemónico para reproducirse, su retóricas y formas de control son, entre otras, las conclusiones que el lector podrá entresacar de estas dos investigaciones que contribuyen a ampliar el panorama de los estudios del discurso aplicado al campo de la educación. 


\section{MAESTROS Y HEGEMONÍA. ANÁLISIS DE TITULARES DEL DIARIO EL TIEMPO: 1977-2005}

\section{Introducción}

En el imaginario de los colombianos, los maestros constituyen un gremio que trabaja poco y gana mucho, o al menos, más de lo que debería. Quienes pertenecemos a este campo laboral y profesional, sabemos que los maestros se quejan del poco estatus social que se les otorga, a pesar de las enormes responsabilidades sociales que se les asigna, que van desde ser educadores hasta ser padres, formadores de ciudadanía, amigos, psicólogos, enfermeros, etc. Los problemas de la educación, la baja calidad y la descomposición social, tienden a asociarse con el ejercicio de sus agentes en la Escuela y, más específicamente, con los maestros. Intuitivamente se piensa que los medios de comunicación tienen que ver con esta mala imagen de los docentes; pareciera que ellos solo son noticia cuando hacen «cosas malas», cuando realizan manifestaciones o protestas, o cuando discuten las decisiones tomadas por el Gobierno; es decir, cuando solo se les puede noticiar por ser agentes del caos social y del desorden público. Pero la verdad, es difícil encontrar estudios sistemáticos que revelen todo el entramado discursivo sobre las representaciones que construyen los medios de comunicación, como miembros de las élites discursivas, respecto a los maestros en Colombia.

Así pues, en este trabajo, desde una perspectiva cualitativa y hermenéutica, se enfoca un sector de la actividad discursiva de nuestro medio sociocultural y se centra la investigación en la figura del maestro del sector público, con el ánimo de desenmascarar las representaciones sociales que cristaliza el discurso mediático, y a partir de las cuales los intérpretes-lectores construyen sentido(s). Desde este marco de acción esencial se establece la pregunta por las fórmulas discursivas genéricas que instituciones simbólicas de poder-como la prensa- han construido sobre la imagen de los maestros y su quehacer pedagógico. En términos de objetivos de investigación, se trata de describir, analizar e interpretar cómo se han representado la figura y las acciones del maestro como actor social en el discurso periodístico, además de qué aspectos de naturaleza sociopolítica e histórica entrañan dichas producciones discursivas.

En efecto, frente al exiguo conocimiento que se tiene sobre el funcionamiento de las operaciones y estrategias usadas en el discurso mediático en cuanto a la formación de modelos mentales y/o representaciones sobre la 
figura del educador y su actuación social, se hizo necesario preguntarse por aquellas tácticas utilizadas en este campo para legitimar políticas que mantienen las desigualdades sociales, que generan exclusión y que sedimentan -en la cognición de la comunidad-ciertas ideologías que pasan como naturales y necesarias. En el contexto histórico actual, medido por la globalización y el dominio mediático, resulta imperante saber cómo se trasmite la información y cómo, a través de ella, se (re)construyen realidades. Indudablemente, los mass media se han convertido en el principal y más sobresaliente mecanismo de control de los comportamientos y los conocimientos.

Lo anterior se adelantó con la conciencia y referencia de estudios ya existentes que, transversalmente, tocaban las variables tenidas en cuenta en este análisis. En Colombia, los trabajos que existen sobre la materia apuestan por las perspectivas históricas y arqueológicas de las prácticas pedagógicas, sin detenerse de manera específica en el entramado discursivo sobre los maestros. En otras latitudes se destacan los estudios que intentan recuperar, desde la investigación narrativa, las representaciones de la práctica y de la profesión de maestro entre los propios actores. Estas perspectivas de trabajo, aunque se inscriben en el área de las representaciones, centran sus objetos de observación en los distintos aspectos de la vida pedagógica y profesional de los actores, sin detenerse en el análisis de las relaciones de poder manifiestas en los discursos de élite. Desde otra perspectiva, la investigación en formación docente es una preocupación de reciente data en el contexto latinoamericano y tiene sus orígenes en las tensiones que se suscitaron entre las fuerzas hegemónicas de los estados nacionales, desde las cuales se impusieron lógicas tecnocráticas y políticas educativas oficiales -como la tecnología educativa de los años 60 y 70 y las consecuentes reacciones de los magisterios de cada país- que buscaron modelos alternos
(...) enmarcados en un proyecto social, político y cultural, en el que la defensa de la educación pública se constituía en eje vertebral y en donde los maestros eran concebidos como intelectuales académicos y sujetos sociales, en busca de su propia autonomía, como individuos y como profesionales (Herrera, 2004, p. 4).

Este estudio no pretende de ninguna manera constituirse en un punto cero de análisis y reflexión de los discursos y representaciones sobre y de los maestros. Haciendo uso del ACD, aplicado a un corpus de la prensa nacional (El Tiempo), se une a los precedentes, los complementa y presenta una manera particular de abordar el tema de las representaciones de los maestros, de alto impacto por su novedad en el espacio de los estudios de discurso, pues indaga sobre esta problemática desde técnicas no hechas 
específicamente con métodos como los aquí trazados y con el intervalo de producción discursiva tratado, pues el estudio de las representaciones discursivas sobre los maestros se centra en ese periodo particularmente conflictivo de la historia del Magisterio, comprendido entre los años 1977 y 2005, que abre y cierra un ciclo importante de luchas políticas en torno al Estatuto docente y en el que, con mayor fuerza, se acentuaron las representaciones del maestro y sus acciones.

Dado que la investigación se propone analizar las representaciones sociales del maestro -manifiestas en el discurso oficial- como premisa para construir unas apuestas interpretativas sobre las «retóricas» a las que los actores sociales apelan para justificar y legitimar intereses, fines y/o acciones en sus conflictos, aquí se adelantan algunos señalamientos sobre la comprensión que se acuña en la investigación respecto a los conceptos de discurso y representación social, desde la apuesta de paradigmas inscritos en los estudios críticos del discurso y, principalmente, desde el Análisis del Discurso (AD) y el Análisis Crítico del Discurso (ACD).

\section{Horizonte conceptual}

\subsection{Los estudios críticos del discurso}

El análisis del discurso surge en la década de 1980 en el Reino Unido con los trabajos M. Halliday y M. Stubb, quienes intentan integrar el lenguaje y la sociedad. El lenguaje es tomado como mecanismo fundamental en la interacción social, pues es a través suyo que las personas interactúan. Los analistas del discurso se interesan por lo que las personas pueden hacer con el discurso. Sus nuevos centros de interés investigativo se orientan a indagar por cuestiones como el papel del lenguaje en los procesos de socialización, en la trasmisión de valores y conocimientos o en el mantenimiento de las estructuras sociales. Se parte de la idea de discurso como hecho complejo en el que se conjugan aspectos verbales propiamente dichos (texto), aspectos relativos a la cognición (representaciones) y a la interacción social (acción). De esta manera los discursos no son solo palabras, sino palabras «acerca de algo» y, sobre todo, palabras con las que «hacemos algo».

El ACD es una proyección del AD. Fue desarrollado en Europa a partir de 1980 por autores como Fairclough, Wodak y Van Dijk, quienes se preocuparon por las escasas relaciones que los investigadores del lenguaje esta- 
blecían entre el contexto político, el social y el discurso. El ACD se relaciona con el poder y el abuso de poder, y con la producción y reproducción de estos en el discurso. Se enfoca en los grupos e instituciones dominantes y en la forma en que estas crean y mantienen la desigualdad social por medio de la comunicación y el uso de la lengua (Van Dijk, 2004a, p. 8).

El poder y el abuso de poder constituyen el marco de interpretación del ACD. Van Dijk define el poder en términos de control, aquel que un grupo o institución ejerce sobre otras personas. Comúnmente se considera que el poder se basa en la posesión de recursos como el dinero, las propiedades y otros bienes materiales; pero el poder también incluye la tenencia de conocimiento, fama o cultura, los que se conocen como recursos simbólicos. No obstante, otra forma de poder, quizá de las más importantes, la constituye el acceso al discurso público. Los políticos, periodistas, docentes y otras «élites simbólicas» tienen más acceso a este poder que el grueso de la población. Estas élites controlan los discursos públicos: políticos, mediáticos, educativos, científicos -entre otros-, lo que implica la elección de los temas de que se habla, los protagonistas -generalmente ellos mismos- y la manera en que se representan. Para este autor, el poder discursivo es mental; es un mecanismo para controlar las mentes de las personas, lo que lleva, acto seguido, al control de sus acciones. Pero para los analistas críticos, el discurso no solo se ubica en el nivel de las acciones y los comportamientos, sino también en el de la cognición, que trata de la manipulación de los conocimientos, las actitudes y las ideologías, normas y valores, es decir, de las representaciones sociales.

En términos cognitivos, el poderoso influye sobre los modelos mentales (personales) de otros grupos, hasta terminar moldeándolos. La memoria social, también llamada representación social, es el conjunto de creencias compartidas que, consideradas verdaderas por tradición y sin sometimiento crítico motivado, se halla debajo de las atribuciones comunes de los miembros de un grupo o de una sociedad y configura la manera de interpretar y de pensar la realidad. Por esto, las representaciones sociales (RS) deben ser comprendidas como el conjunto de

(...) construcciones simbólicas individuales y/o colectivas a las que los sujetos apelan o las que crean para interpretar el mundo, para reflexionar sobre su propia situación y la de los demás y para determinar el alcance y la posibilidad de su acción histórica (Vasilachis, 1998, p. 301).

El presupuesto básico de la teoría de los estudios sobre representaciones sociales es que la formación de las opiniones y visiones de la realidad no es un proceso individual o idiosincrásico. La inserción de los individuos en 
distintas categorías sociales y su adscripción a diversos grupos son fuentes de determinación de las RS y generan visiones compartidas e interpretaciones similares de una misma realidad. Así, las RS estarían determinadas por el medio cultural en que se vive, el lugar que se ocupa en la sociedad y por las experiencias concretas individuales.

Las RS intentan dar cuenta de la manera como se forma nuestra visión de la realidad y cómo incide esta visión en las conductas cotidianas. Las RS son un mecanismo que permite comprender al «otro», saber cómo comportarnos ante él, y lo que es más importante, permiten asignarle un lugar dentro de la sociedad. Por su naturaleza, se identifican con todos los implícitos de cualquier discurso. Por ser compartidas socialmente, influyen también en las creencias personales sobre los modelos subjetivos. De hecho, no se puede construir un modelo mental sin esas representaciones sociales. Por tanto, influir en las creencias socialmente compartidas es la otra forma de control discursivo de la mente.

La forma más generalizada de acceder a las representaciones sociales de un grupo es a través de sus discursos, los cuales se someten a diversos tipos de observaciones, desde los típicos análisis de contenido, hasta los análisis de similitudes, de correspondencias semánticas o incluso técnicas experimentales. Para los analistas, las representaciones sociales son parte constitutiva de los discursos y su recuperación se puede hacer desde varios tipos de análisis, algunos de los cuales se plantean a continuación.

\subsection{El problema de la ideología}

Desde que Destutt de Tracy introdujo el concepto de ideología en Francia en el siglo XVIII como la "ciencia de las ideas», muchas páginas se han escrito sobre el tema. Los mayores aportes han sido hechos fundamentalmente desde la sociología y la filosofía. Se ha relacionado con aspectos como las clases sociales, los grupos dominantes, los movimientos sociales, el poder, la dominación o la economía política. Son innumerables los autores que han enriquecido la teoría, pero si hay uno con el cual se asocie la ideología, es con Carl Marx, aunque también han contribuido al debate Gramsci, Durkheim, Althusser o Luckacks, por citar tan solo algunos.

En general, siguiendo a Marx y Engels, se habla de ideologías dominantes de una época y de una clase social determinada. Se asocian con la base social y el «material» de la sociedad, y se convierten en un concepto central al tratar de explicar la manera como las clases altas controlan los medios de producción y, de paso, las ideologías de las personas, convirtiéndolas 
en asuntos naturales e incuestionables. Esta especie de determinismo económico sería fuertemente criticado por los sucesores de las teorías de estos autores. Gramsci (1975) introduce el concepto de hegemonía para referirse no a una imposición vertical de las ideas dominantes, sino a un tipo de imposición de ideas más sutil, aceptada por los grupos dominados que dan la impresión de consenso sobre el orden social, sobre la naturaleza de la sociedad y su lugar en ella.

Como resalta Van Dijk (1999) desde sus inicios, el concepto de ideología tomó cierto carácter negativo al definirse como un sistema de creencias erróneas, al relacionarse con una supuesta «falsa conciencia» y al asociarse a las ideas de los políticos y de todos aquellos que no compartían nuestras mismas opiniones. Las ideologías serían, pues, las ideas que tienen los otros. Los sistemas de creencias sociales y religiosas de los grupos dominantes pocas veces se asocian con la ideología. Con frecuencia se empleó para referirse al comunismo y se opuso al concepto de verdad.

En la actualidad, a pesar de la desaparición de los regímenes políticos y económicos con los cuales se asoció la ideología, esta, vista como efecto del poder socioeconómico o simbólico, sigue siendo de gran interés para los académicos, en especial para aquellos que adoptan perspectivas críticas en los estudios sociales y en los más recientes estudios culturales. Poco a poco ha ido perdiendo su carácter peyorativo, se ha asociado con ideas más inclusivas y se ha redefinido como sistema de creencias, valores, ideas políticas o sociales propias de colectividades, que cumplen la función de organizar y legitimar acciones de grupo (Tajfel, Van Dijk, Angenot).

Sin embargo, ideología es un concepto que se emplea con bastante frecuencia y poca precisión teórica, quizá como sucede con otros conceptos como poder, conocimiento o representación social. Poco se sabe, por ejemplo, del estatus general de la ideología como sistema cognitivo y social, de su composición interna o estructural, o la diferencia entre ideología y otros sistemas de creencias; tampoco se relaciona con conceptos clave como discurso, a pesar de que muchos señalan el papel de este en su (re)producción.

Señala Van Dijk que aunque hay un consenso entre los académicos para aceptar que las ideologías tienen un lado cognitivo, social y discursivo, reconocen que son «sistemas de ideas», y por tanto se relacionan con el campo del pensamiento y las creencias; son sociales, ya que se asocian con intereses, conflictos y luchas de grupos, y se utilizan para legitimar y oponerse al poder y la dominación; y son discursivas, pues se expresan y reproducen a través del discurso, aunque pocos autores conceden especial atención a las dimensiones cognitivas y discursivas de las ideologías. 
Van Dijk propone explicar la ideología a partir de estos tres elementos constitutivos. En su modelo teórico, busca entender la manera como la ideología moldea el discurso e inversamente, cómo la misma se forma, adquiere y cambia por medio del discurso y la comunicación (1999, p. 10). La propuesta de este autor se centra en tres conceptos fundamentales: cognición, sociedad y discurso, de donde se desprende que ciencias como la psicología, la sociología y la lingüística tienen mucho que aportar al respecto. Van Dijk reformula e integra estos conceptos en una estructura teórica que dé sentido al concepto de ideología. Relaciona el discurso con estructuras y estrategias de la mente y la sociedad, así como con situaciones, interacciones y estructuras sociales. Dentro de este triángulo, la cognición es tomada como la interfaz que conecta al discurso con la sociedad.

Van Dijk comienza planteando la ideología como la base de las representaciones sociales compartidas por los miembros de un grupo. Lo que implica que la ideología permite a las personas, como miembros de grupo, organizar las creencias sociales acerca de lo que sucede, bueno o malo, deseable o indeseable, correcto o incorrecto, y acto seguido actuar en consecuencia. Las ideologías, por tanto, influyen en lo que se acepta como verdadero a falso, en especial cuando estas creencias son consideradas importantes por el grupo. En términos epistemológicos, las ideologías pueden formar la base de argumentos específicos a favor o en contra de algo y de explicaciones sobre el orden social particular.

Para Van Dijk no se trata de una «visión de mundo» de un grupo, sino de los principios que forman la base de tales creencias. Comparte con otras tradiciones epistémicas, la idea de que las ideologías son un marco compartido de ideas que organizan y coordinan las interpretaciones y prácticas sociales de grupo y sus miembros, en particular el poder y otras relaciones de grupo, pero señala que no solo se limitan a encontrarle sentido a la sociedad, sino que también sirven para regular las prácticas, para estabilizar formas particulares de poder y dominación, pero también para resistirlas y cuestionarlas.

Resalta el autor que si bien se trata de un modelo con un fuerte componente cognitivo, por la naturaleza misma de las ideologías, no se reduce a él. Las ideologías no solo se definen en términos cognitivos, sino en términos de grupos sociales, relaciones de grupo e instituciones a nivel macro, y en términos de prácticas sociales, a nivel micro. Enfatiza que las ideologías son construidas, utilizadas y cambiadas por actores sociales como miembros de grupo, en prácticas sociales específicas y frecuentemente discursivas. 
Sin embargo, analíticamente distingue entre las representaciones mentales socialmente compartidas y las prácticas sociales que están controladas por ellas o por medio de las cuales dichas representaciones se construyen. Aclara el autor que para una mejor comprensión de las ideologías, debe distinguirse entre formas de conocimiento cultural y otras creencias compartidas, que son la base común de todo discurso e interacción social.

\section{Hegemonía}

Según Angenot, "la hegemonía completa, en el orden de la "ideología", los sistemas de dominación política y de explotación económica que caracterizan una formación social» (2010, p. 29). La hegemonía discursiva se encargaría de legitimar y controlar las maneras de conocer y de significar lo conocido en una sociedad, es decir, de instituir las reglas generales de lo pensable y decible -y lo escribible- de una época. Para este autor resulta fundamental introducir la hegemonía en el campo del discurso social, en la manera como una sociedad dada se objetiva en textos y escritos. La hegemonía discursiva haría parte de una hegemonía cultural más amplia que establecería la legitimidad y el sentido de los diversos estilos de vida, costumbres, ideas y actitudes de una sociedad. Sin embargo, Angenot no identifica la hegemonía con el conjunto de ideas que prevalecen o dominan una época. Para él la hegemonía es «el conjunto de repertorios y reglas y la topología de los "estatus" que confieren a esas identidades discursivas posiciones de influencia y prestigio, y les procuran estilos, formas, microrrelatos y argumentos que contribuyen a su aceptabilidad» (ibíd., p. 30).

La hegemonía representa un grado mayor de abstracción que las descripciones de los discursos; constituye un sistema unificador y regulador que predetermina la producción discursiva, y cuya función está orientada a la homogenización de las retóricas, las tópicas y las doxas transdiscursivas, y a la institución de las jerarquías de las legitimidades a partir de una relativa estable homogeneidad. Sin embargo, el sistema es un poco más complejo. En la hegemonía intervienen distintos tipos de intereses, estructuras, tradiciones, posiciones adquiridas y defendidas, "pereza» intelectual y adaptación. En ese sentido, el sistema no es totalitario: en él convergen diversos tipos de fuerzas centrífugas -incluso disímiles-, factores de distinción, de disidencias, discursos especializados e incluso paradojas. Fuerzas que tienden a capturarse, pues el discurso social y la hegemonía son dispositivos cuyo fin fundamental es ocultar o desviar la mirada para legitimar y producir consensos, generalmente en torno a los valores defendidos por la clase 
dominante. Aunque de hecho la hegemonía no es propiedad de una clase, su naturaleza es social.

\section{Hegemonía y discurso}

Una vez definidas la hegemonía y las ideologías como representaciones sociales compartidas que tienen funciones sociales específicas para los grupos, se hace necesario explicar su relación con el discurso, esto es, cómo los miembros de los grupos las adquieren, construyen, utilizan y cambian. Sin embargo, señalar el papel del discurso en su producción, no implica reducirlas al discurso o al análisis discursivo que se realice de ellas. Estas también se expresan y reproducen mediante otras prácticas sociales y semióticas diferentes al texto y la conversación (Van Dijk, 1999, p. 245). Sin embargo, negar el papel fundamental del discurso en la (re) producción de las ideologías también sería un error.

La relación ideología-hegemonía-discurso no es directa, uno a uno. El discurso no siempre es ideológicamente trasparente, y los análisis que se puedan hacer no siempre permiten inferir las creencias ideológicas de las personas. Las ideologías dependen de los contextos y de la representación que los hablantes tengan de ellos. Lo que implica que las metodologías empleadas deben basarse en métodos indirectos, especiales y discretos.

El análisis del discurso parte de la idea de que si las ideologías son adquiridas, expresadas y reproducidas por el discurso, este proceso se realiza a través de varias estructuras y estrategias discursivas.

\section{Estructuras discursivas}

En teoría, cualquiera de las estructuras del discurso -fonéticas, morfológicas, sintácticas, semánticas o pragmáticas- puede estar ideológicamente marcada. Sin embargo, algunas de estas estructuras son más sensibles que otras, por ejemplo los significados o la selección de determinados temas versus las estructuras sintácticas, que tienen un carácter más fijo. Si como se señaló, la polarización de los grupos es el esquema preferido de las ideologías, este hecho debe reflejarse en el discurso, lo que puede evidenciarse en el uso de los pronombres de tercera persona como nosotros y ellos. Van Dijk resume las posibilidades de variación estructural en el siguiente cuadro (1996, p. 27). 


\section{ESTRUCTURAS VARIABLES DEL DISCURSO}

- Estructuras fonológicas (tensión, picos, volumen, entonación).

- Estructuras gráficas (encabezados, caracteres en negritas).

- El ordenamiento y el tamaño generales (primero y después, más alto/ más bajo, más grande o más pequeño, preponderancia e inferioridad).

- Estructuras sintácticas (el orden de las palabras, la topicalización, las relaciones de cláusulas: principal y subordinada, frontal o encastrada; construcciones divididas).

- Estructuras semánticas (explícito vs. implícito, detalle y nivel de descripción, macroestructuras semánticas vs. detalles).

- Estilo léxico (palabras de opinión positivas vs. negativas).

- Estilo retórico (sobre y subestimación, eufemismo, litotes; repetición).

- Esquemas o superestructuras (expresadas -o no- en categorías convencionales prominentes, por ejemplo, encabezados o conclusión, relato y argumentación).

- Estilo pragmático (aserción contra negación; autocomplacencia vs. acusación).

- Estilo interactivo (tomar su turno: autoselección y predominancia; mantenimiento y cambio de tópicos; comunicación no verbal: rostro, gestos).

Cuadro 1. Estructuras variables del discurso

Estas estructuras del discurso tienen la función de poner en juego ideologías subyacentes y funcionar como medios de persuasión más o menos eficientes.

\section{Estrategias discursivas}

Las estructuras ideológicas en general se corresponden con estrategias discursivas empleadas por los hablantes. Estas se definen como formas en que los objetos son gradualmente construidos o interpretados y explican lo que los actores sociales, pensadores o usuarios del lenguaje hacen en situaciones concretas. Según Angenot:

lo que se enuncia en la vida social acusa estrategias por las que el enunciado "reconoce» su posicionamiento en la economía discursiva y opera según este reconocimiento; el discurso social, como unidad global, es la resultante de esas estrategias múltiples, aunque no aleatorias (2010, p. 25).

La estrategia ideológica mayormente estudiada es la auto representación positiva (alarde) y la representación negativa del otro (detracción). Esta estrategia hace énfasis en nuestras cosas buenas y oculta o desestima las ma- 
las; y a la inversa, resalta las cosas malas de los otros y oculta o desestima sus aspectos positivos.

La aplicación de lo que se conoce como el cuadrado ideológico implica una afectación general de las formas y significados del discurso. Por ejemplo, la prensa puede reforzar las características negativas de los grupos guerrilleros haciendo uso de las estructuras esquemáticas de los diarios, señalando actos repugnantes cometidos por ellos, ya sea ubicándolos en la primera página, con grandes titulares, con fotografías, empleando estructuras sintácticas en las que se señalen como agentes activos de las acciones o como responsables al colocarlos en las posiciones de sujeto, o haciendo uso de selecciones léxicas particulares al nombrarlos como «terroristas» o «asesinos», entre otras muchas estrategias discursivas.

Algunas de las estrategias ya evidenciadas suponen:

- Legitimación/deslegitimación. Afirmación o negación de que las acciones realizadas por un grupo o persona están dentro del orden moral general.

- Naturalización de la acción. Procedimiento mediante el cual no se nombran los agentes de las acciones, lo que permite inferir que los acontecimientos se precipitan solos y que dichas acciones ocurren de manera natural e inevitable, lo que dificulta identificar a los responsables de las acciones. Supone una línea de progreso objetivo cuyas etapas supuestamente deberíamos recorrer.

- Parcialización. Estrategia discursiva en la que la información sobre los diversos actores y acciones es incompleta al no ofrecer las causas o consecuencias que generan los hechos y al privilegiar aspectos particulares de la información de manera arbitraria (Soler, 2009). Ocurre cuando no se presentan fuentes alternativas de información y marcos de interpretación diversos.

- Maximización/minimización. Buscan intensificar o mitigar la fuerza ilocucionaria de las afirmaciones.

- Generalización. Aplican las características de una persona o grupo a un grupo más amplio.

- Lexicalización positiva o negativa. Selección de palabras aplicables a cada grupo de manera preferente.

- Uso de hipérboles. Descripción de un acontecimiento o acción en términos muy exagerados.

- Aliteración. Permite destacar la importancia o relieve de determinadas palabras o frases.

- Estrategias argumentativas. Dan cuenta de los presupuestos utilizados para justificar o legitimar las acciones o las representaciones de los actores sociales. 
Como señala Van Dijk, el propósito del análisis ideológico del discurso no es «descubrir» las ideologías subyacentes en los textos o el discurso, sino articular sistemáticamente las estructuras del discurso con las estructuras ideológicas, con el fin de explicar qué expresiones o significados discursivos permiten hablar de qué clase de inferencias y otros procesos mentales, más allá del propio sentido común de las personas (1996, p. 24).

\section{Metodología}

Para hablar de metodologías dentro del AD y ACD, es importante resaltar que independientemente del enfoque que se siga para el análisis de los datos (neomarxista, de Norman Fairclough; historicista, de Ruth Wodak o cognitivo, de Van Dijk, entre otros), el ACD requiere una sólida base lingüística -formal y funcional- que incluye las formas gramaticales, retóricas, semióticas, estilísticas pragmáticas o de interacción. Los analistas críticos reiteran la importancia de señalar que el ACD no es un método o enfoque que se aplica a los problemas sociales. No es una caja de herramienta para aplicar a X o Y problema. Se trata más bien de una disciplina transversal, teórica y metodológica que se subdivide y emplea aportes de otras subdisciplinas y áreas de conocimiento. Cada estudio emprendido está sujeto a un completo análisis teórico social, de manera que se pueda saber con certeza qué discursos y qué estructuras se han de analizar y relacionar. No todos los aspectos del análisis lingüístico se aplican siempre, ni tampoco de la misma manera. El marco analítico dependerá en todo caso del problema, los objetivos y el alcance de la propuesta de investigación y de la perspectiva teórica del analista.

Para este análisis en particular se siguieron los planteamientos de Van Dijk y Wodak, que buscan dar una explicación sistemática de las complejas estructuras y estrategias del discurso como ocurren en contextos sociales reales. Se procede al análisis de las estructuras discursivas jerarquizadas e interdependientes, que van desde los niveles básicos de análisis lingüístico hasta las superestructuras textuales.

En el análisis se comienza por identificar las estructuras semánticas de los textos. En esta investigación se trabajan los conceptos de tema y tópico. El primero, entendido como la macroestructura o descripción semántica del contenido de los discursos, cuya función consiste en determinar la organización de significado y señalar los aspectos esenciales de un discurso mediante el uso de unidades denominadas macroproposiciones (Van Dijk, 1995). Las macroestructuras semánticas permiten dar cuenta de conceptos 
como coherencia global o tema, término este último que, de manera muy vaga, responde a la pregunta de «acerca» de qué trata algo (Van Dijk, 1995, p. 196). Los temas se pueden expresar como macroproposiciones o mediante abstracciones mayores, reduciéndose a una sola palabra o categoría que refiere ese contenido global de los temas, tal como lo señala Bublitz (1988, p. 23). En esta investigación se mostrarán las dos posibilidades, teniendo en cuenta las especificidades de los tipos de corpus analizados.

El segundo término, tópico, permite identificar las diversas secuencias discursivas que posibilitan hablar de un tema determinado. Así, cada tema se compondrá de una secuencia de frases o proposiciones relacionadas entre sí (tópicos), que satisfacen directa o indirectamente el criterio de dicho tema. Y si -como se dijo- el tema da cuenta de acerca de qué trata algo, el tópico señala qué se dice con exactitud sobre ese algo. Para llegar al tema se requieren procesos mentales inferenciales; para llegar a los tópicos, basta examinar los hechos más específicos inscritos en el texto.

El análisis de las macroestructuras semánticas permitió establecer, además, las estrategias discursivas usadas por el diario El Tiempo al referirse a los maestros y sus acciones. El objetivo de hallar estas estrategias es evidenciar, a través de qué argumentos, determinados grupos sociales justifican y legitiman la exclusión, discriminación o explotación de los «otros».

Estas estrategias incluyen:

1. La manera como se nombran los actores sociales; categorización de la pertenencia: empleo de nombres propios, sustantivos colectivos, metáforas, metonimias, despersonalizaciones, etc.

2. Los tipos de predicado que se les atribuye: atribuciones estereotipadas o valorativas, mención de acciones positivas o negativas mayoritariamente.

3. Las justificaciones de los atributos positivos o negativos: Topoi o esquemas argumentativos que justifican la inclusión o exclusión, discriminación o trato preferente; algunos de estos topoi evidenciados en la literatura incluyen, por ejemplo, la representación positiva del endogrupo y la representación negativa del exogrupo, la parcialización y tergiversación de la información, la invisibilización o la amenaza. Al respecto puede consultarse a Wodak, 2003; Martín y Van Dijk, 1998; Vasilachis, 1998; Soler, 2009; y Van Leeuwen, 1996.

4. La revisión de las estructuras esquemáticas del corpus, en la que se analiza la ubicación de la noticia dentro del diario. Esto nos permitió mostrar qué noticias prioriza el diario. Qué merece aparecer en la primera página y qué no. 
Delimitación y manejo del corpus. Como ya se mencionó en la introducción de este trabajo, el corpus base de análisis se centró en las noticias publicadas en el diario El Tiempo ${ }^{2}$, en el periodo particularmente conflictivo de la historia del Magisterio, comprendido entre los años 1977 y 2005, que abre y cierra un ciclo importante de luchas políticas en torno al Estatuto docente y en el que, con mayor fuerza, se acentuaron representaciones sobre el maestro y sus acciones. Se recopilaron, dentro del intervalo de tiempo arriba esbozado, los titulares a propósito de noticias que involucraban a los maestros del sector público de la educación básica y media de Colombia. La selección incluyó otros elementos relacionados con los maestros, como los gremios de maestros y los actores del Estado responsables de la educación en Colombia: ministros de educación, secretarios de educación, presidentes, etc.

La búsqueda de las noticias se realizó en la Hemeroteca de la Biblioteca Luis Ángel Arango. El proceso fue el siguiente: una vez identificada la noticia, se procedió a escanearla y archivarla de manera digital. Esta revisión incluyó los años comprendidos entre 1977 y 1990, cuando el periódico se digitalizó. A partir de esta fecha, se accedió a las noticias directamente en las instalaciones del diario El Tiempo, donde se tiene un archivo digital. Allí, a través de programas de búsqueda de información, se seleccionaron las noticias que cumplían los mismos requisitos anteriormente señalados. Una vez recopilados los dos corpus, se procedió a etiquetarlos mediante los siguientes criterios: titular, fecha y sección del periódico en el que aparece la noticia. Esta primera sistematización de la información permitió depurar el corpus, en el sentido de verificar si las noticias respondían a los criterios establecidos y si se referían a profesores oficiales. Se eliminaron todos los titulares que hablaban de profesores universitarios y de la educación privada. Esto produjo un total de 1814 noticias.

2 El Tiempo es el diario de mayor circulación en Colombia. Fue fundado el 30 de enero de 1911 por Alfonso Villegas Restrepo, pero rápidamente pasó a ser propiedad de la familia Santos, quienes se desempeñaron como propietarios directores durante buena parte del siglo xx. Es un diario de tendencia liberal, que históricamente ha participado indirecta y directamente en la política del país. Eduardo Santos, su director, después de ejercer varios cargos, entre ellos el de ministro, fue elegido presidente de la república entre 1938 y 1942 . El Tiempo fue cerrado entre 1955 y 1957 a causa de la censura impuesta por la dictadura de la época. Apoyó el Frente Nacional entre 1958 y 1974. En 2007, el grupo español Planeta adquirió el 55\% de las acciones de El Tiempo, que vendió posteriormente en 2011 al empresario colombiano Luis Carlos Sarmiento Angulo, quien además compró el 33\% perteneciente a los accionistas minoritarios. 
La magnitud del corpus obligó a tomar decisiones procedimentales. Se decidió examinar únicamente los titulares y recurrir al cuerpo de la noticia solo para comprobar algunos aspectos de la información que no fueran claros en el titular; por ejemplo, si se trataba de profesores de la educación pública, o si se hablaba de ellos de manera positiva o negativa. Esta decisión se tomó teniendo en cuenta que los titulares son el elemento cardinal de los textos, pues expresan o resumen su estructura temática. Para autores como Van Dijk (1990), los titulares son el elemento más destacado de la noticia. Son los que reducen, organizan y categorizan la información semántica de un texto. Proveen además el marco dentro del cual se debe interpretar la noticia. Al resumir la parte más importante de la noticia y darle coherencia, resultan fundamentales en el momento de procesar la información y guiar su lectura. Por tanto, como lo señala Vasilachis, "los titulares tienen un papel relevante en lo que se vincula con la construcción social de la realidad a través de la comunicación de masas» (1998, p. 36). Incluso para autores como Charaudeau (1983), las características de los titulares hacen que estos puedan considerarse textos autónomos e independientes.

Sin embargo, y aunque existen investigaciones basadas únicamente en el análisis de titulares (Vasilachis, 1998), es importante resaltar que hay que proceder con cautela y en lo posible recurrir al cuerpo de la noticia antes de establecer conclusiones o generalizaciones. Es fundamental señalar también que algunos de los análisis microtextuales que se hacen dentro del análisis del discurso son poco aplicables al análisis de titulares de prensa, pues los diarios han establecido reglas y formas de redacción propias, que favorecen, por ejemplo, las nominalizaciones, la elisión de sujetos o el empleo de metáforas; mecanismos profundamente criticados por los analistas de discurso, al considerar que éstos eluden responsabilidades de los agentes de las acciones, Ilevan a malos entendidos o dificultan la comprensión al emplear demasiados elementos contextuales.

No obstante, de lo que se trata en este tipo de análisis es de mostrar cómo los diarios no redactan sus noticias de la misma manera, independientemente de los actores sociales. Existen actores que son noticiables, que tienen nombre propio, que hacen cosas positivas y tienen voz, y existen otros actores que son solo una masa homogénea, que se comporta de manera homogénea y que no tiene derecho a que se escuche su voz, excepto cuando se refiere a acciones negativas. 


\section{Análisis}

Nos gustaría iniciar este apartado de investigación con las palabras de Jaume Carbonell y Antoni Tort, que aparecen en el prólogo de su libro La educación y su representación en los medios, el cual comparte algunos de sus objetivos con esta investigación. Señalan los autores que:

(...) entre la educación y los medios de comunicación hay una relación de desconfianza mutua. Desde el sector educativo existe un recelo bastante justificado del abordaje mediático de los temas que le conciernen. Y desde los medios, la información relativa al sector no merece un tratamiento prioritario $(2006$, p. 11).

Esta dinámica, sin duda alguna, está presente también en Colombia y gobierna las relaciones de estos grupos. Los medios de comunicación tienen la función y el compromiso de informar; ese es el papel que les asignó la sociedad. Sin embargo, cada día adquieren un rol más activo y desplazan sus intereses hacia el formar, tomando partido en los conflictos, incluso injiriendo en asuntos relevantes de las agendas políticas y sociales e imponiendo visiones de realidad. Aunque la educación, y en particular los maestros, no parecen estar en las agendas de los medios.

Contrariamente al discurso público oficial, e incluso al cotidiano, que señala a la educación como el principal medio de transformación social que permitirá salir del subdesarrollo y la pobreza, la clave del progreso y el bienestar social (la educación) no está entre los temas prioritarios de los medios; no es una cuestión noticiable, excepto si «algo extraordinario pasa». Según encuestas realizadas en España y Latinoamérica, las cifras de interés de las audiencias por la educación están entre 3 y 5\%, y eso en los momentos más conflictivos. Esas encuestas señalan que los temas más relevantes para los lectores de diarios en España son los deportes, los espectáculos, el tiempo, las curiosidades o las cartas al director. La educación escasamente aparece como tema de interés. Esto hace que los medios, cada vez más presionados por las audiencias y el mercado, opten por no incluir este tipo de noticias. Varias encuestas realizadas en Argentina señalan el escaso interés por el tema educativo. La educación ocupa el octavo lugar de preferencias, después de temas como la política, los deportes, la información general, la economía, los espectáculos e, incluso, los avisos clasificados (citado en Carbonell y Tort, 2006, p. 16). Señalan los autores, a manera de curiosidad, que en alguna oportunidad los diarios de España decidieron quitar el horóscopo de sus páginas, y recibieron cientos de cartas de protesta, de tal suerte que los dueños del periódico tuvieron que incluirlo de nuevo. La pregunta sería, ¿qué pasaría si eliminaran la sección educativa de los diarios? 
La educación, dentro de lo noticiable, parece obedecer a la lógica con la que se tratan otros temas sociales: es noticia solo aquello que se salga de lo cotidiano, que traspase los límites de la normalidad social. Los maestros son noticia cuando hay hechos que así lo ameritan: agresiones o conflictos, cuando son víctimas de violencia ejercida en las aulas, cuando son cuestionados sus conocimientos o su ser profesional, o cuando hay intereses políticos de por medio para informar -en el caso de reformas o evaluación de algún tipo de administración-.

Pero la realidad educativa que trasmiten los medios no es la realidad en sí; como noticia, es una construcción de los periodistas, pues son estos quienes la recogen, organizan y presentan de acuerdo con sus intereses y los de los diarios. Y aunque éstos diferencian las noticias «puras» de aquellas de opinión, que se basan en interpretaciones de los hechos, muchas veces esta línea divisoria se rompe y la noticia, como tal, aquella que tiene el significado menos ambiguo, es cada vez más escasa en los medios de comunicación. De esta manera, dejan de cumplir su función de explicar los hechos con claridad y precisión, y de incluir el mayor número de datos posible que permita al lector formarse una idea completa del hecho noticiable, para asumir los roles de otros actores sociales como la familia o la escuela, cuya función es la trasmisión de valores.

\subsection{Construcción de la agenda temática del diario El Tiempo}

En la construcción de la noticia, el diario El Tiempo parece obedecer a la lógica señalada por Armentia y Caminos, «cuando más negativas sean las consecuencias de un hecho, más posibilidades tiene de ser noticia, cuanto más cruento e insólito es el espectáculo, mayor es su valor noticia» (2003). Las noticias sobre los maestros señalan sus luchas, pero las presentan como conflictos; los maestros son representados como actores sociales carentes y desviados de la norma o como espectáculos en los que lo importante es su «a-normalidad». En pocas ocasiones se registran hechos positivos.

Las temáticas aparecidas en el diario El Tiempo durante el periodo analizado (1977-2005) obedecen en términos generales a esta lógica. Para la presentación las hemos dividido, primero, de acuerdo con las acciones que se predican de los maestros y el gremio de maestros, y segundo, con la representación de actores: maestros, actores oficiales y gremios de maestros. Las primeras se pueden clasificar de acuerdo con su recurrencia en: (1) huelgas, paros o ceses laborales; (2) aspectos judiciales; (3) sueldos y presupuesto para la educación; (4) aspectos académicos; (5) aspectos legales: 
leyes, reglamentos, estatutos; (6) reconocimientos; (7) curiosidades; y (8) bienestar social.

\section{Temáticas en los titulares del diario El Tiempo}

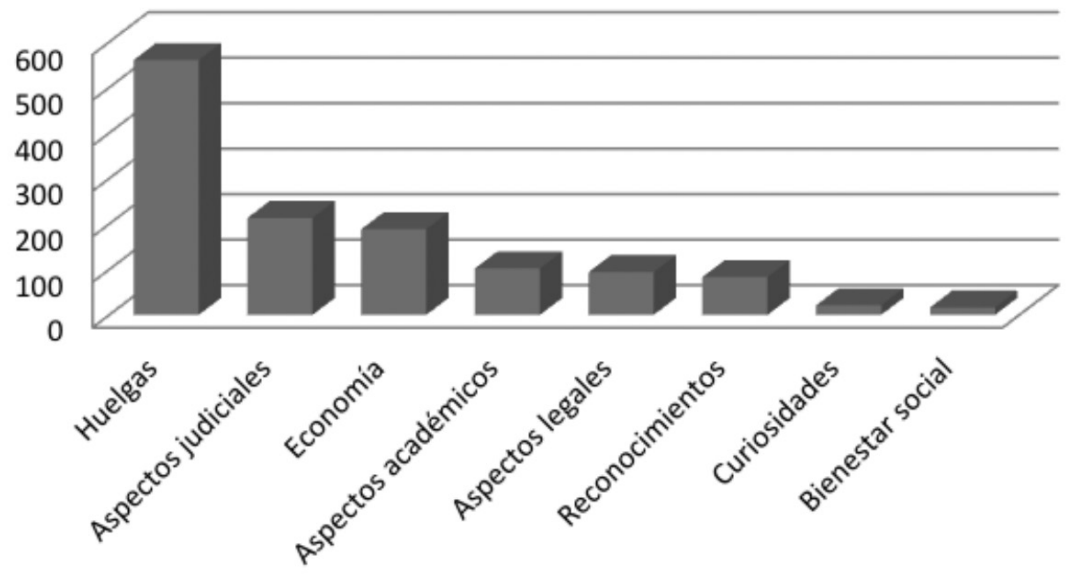

Gráfica 1. Frecuencia de las temáticas aparecidas en el diario El Tiempo

A continuación se desarrollará cada uno de estos temas de acuerdo con su frecuencia de aparición en las noticias.

\subsubsection{Huelgas, paros y ceses laborales}

Como se evidencia en el gráfico, el tema de las huelgas, los paros y los ceses laborales presenta la mayor recurrencia en los titulares analizados (560). En estos, cada año de manera repetitiva podría trazarse una bitácora en la que el año escolar se inicia en enero con profesores y gremios de educadores en estado de «alerta», que pasan en febrero a «amenazar» 0 «anunciar» «huelgas», «paros», «mítines», «protestas» o «marchas»; tiempo en el que se inician «diálogos» o «conversaciones» entre los gremios y el gobierno (quien «promete» $y$ «asegura» soluciones prontas), quienes finalmente logran «acuerdos» que conducen a «levantar», «suspender», «cesar», «terminar» o «finalizar» el «paro» y «reiniciar» o «regresar»a las clases. En marzo se inicia un periodo de normalidad que concluye a mediados de junio, cuando el gobierno no ha cumplido lo pactado; el gremio de maestros inicia de nuevo los paros, con la misma dinámica de la primera mitad del año, con diálogos que conducen a acuerdos de levantamiento de huelgas. A finales de noviembre y comienzos de diciembre se inician nuevos ceses de maestros que «amenazan» con no entregar notas finales. Esta situación se resuelve antes o después de las navidades, para salir a vacaciones a esperar que el año siguiente se repita la misma historia. 
El tratamiento temático puede analizarse como sigue:

\section{«Hoy, paro nacional de maestros» (HS95)}

El tratamiento más generalizado en los titulares es la enunciación de los acontecimientos sin causas, lo que representa una clara parcialización en la noticia. Como se señaló en otro trabajo, la parcialización es una estrategia discursiva en la que la información sobre los diversos actores y acciones es incompleta al no ofrecer las causas o consecuencias que generan los hechos y al privilegiar aspectos particulares de la información de manera arbitraria (Soler, 2009). El diario El Tiempo poco señala en sus titulares las causas de las huelgas. Tan solo 30 de los 560 titulares de prensa las mencionan: falta o demora en los pagos (HS40, HS45, HS71, HS109, HS110, HS136, Hs155, Hs249), amenazas o muerte de educadores (HS231, hs244, HS258, HS260, HS327, HS334, HS337, HS404, HS505, HS512, HS514, HS517), traslados (HS474), decretos (HS50, Hs250, HS364, HS554), falta de presupuesto (HS401), despidos (hS140), falta de profesores (HS10, HS144, HS232), conflictos en los departamentos (HS234), hambre (HS536), despidos (HS140, HS 328), por sus derechos (HS513). De esta manera, es poca la información que suministra el diario en los titulares para que el lector pueda hacerse una idea más completa de las demandas de los maestros y las razones por las cuales se ve obligado a realizar marchas. Sumado a lo anterior, la manera como titula el diario -a pesar de indicar las causas de los paros- no establece una clara relación entre los elementos del enunciado, y recurre demasiado a implícitos o presupuestos en los que el lector tendría que realizar las asociaciones pues el diario no las presenta: así, por ejemplo en titulares como «Ya les pagamos... por favor inicien clase» (HS71), «Giran 5200 millones a los maestros, pero sigue el paro» (HS109) o «Revelan tabla de alza salarial para maestros y persiste el paro» (HS110), más que una causa directa, el lector debe hacer procesos de inferencia y concluir que el origen del paro es la falta o demora en los pagos. Igual sucede cuando las causas son amenazas de muerte o asesinatos de maestros; el diario El tiempo construye titulares como «Paro en Urabá por muerte de una profesora» (HS334), en el que se supone que se trata en realidad de un asesinato, pero la selección léxica no permite establecer relaciones exactas, o en el titular «Maestros protestan por crímenes» (HS337), en el que no está claro si se trata de crímenes que se suceden en la sociedad o crímenes de los que ellos son víctimas.

\section{«Paro docente será declarado ilegal»(HS381)}

Deslegitimar o atribuir carácter negativo a las acciones de los «otros» constituye una estrategia clave para construir una imagen distorsionada de la 
realidad. En algunos de los titulares, el diario menciona el carácter ilegal de las marchas, olvidando el derecho del trabajador a la huelga y a manifestar su inconformidad ante las injustas condiciones laborales. En consecuencia, se leen titulares como «Paro docente será declarado ilegal» (HS381), «Gobierno declara ilegal paro docente» (HS388) o «Prohibido parar» (HS492). Lo que permite, acto seguido, legitimar sanciones a los maestros que entren en paro o amenazarlos con descuentos en el salario o despidos. Así, se leen titulares del tipo «Sancionarán a maestros en paro» (HS455), «A maestros que paren no se les pagará» (Hs543) o «Maestros en paro serían despedidos» (HS447).

Esta condición de ilegalidad se refuerza con titulares como «No hay razón para el paro» (HS308), "Paro de maestros, es "injusto con Bogotá"» (HS308) o que «El paro de maestros es absurdo e injusto» (AO39).

El diario también emplea otra estrategia discursiva para deslegitimar las acciones de los maestros al atribuirles carácter repetitivo y convertirlas en costumbre: «Uno, dos, tres, maestros otra vez» (HS465), «Otra protesta de los docentes» (HS265), «Maestros vuelven a hacer paro hoy» (HS318) o «Quinto paro de maestros este año» (HS96). Pero en su afán por presentar una imagen negativa de los maestros, el diario cae en contradicciones al señalar en una misma página noticias como «La amenaza de paro continúa por el eterno descontento de los maestros» (HS273) o «El paro perpetuo» (HS274), junto a «Hoy habrá clases normalmente. Maestros suspenden paro» (Hs275). Se percibe claramente la contradicción entre el adjetivo «perpetuo» y el anuncio de suspensión del paro.

En otras ocasiones el diario recurre a mostrar una imagen negativa de las acciones de los maestros al señalar supuestas contradicciones en su accionar. Presenta titulares como «Educadores piden diálogo pero insisten en el paro» (HS21), "Suben salarios de comunicaciones y maestros: FECODE anuncia paro» (HS72) o "Revelan tabla de alza salarial para maestros y persiste el paro» (Hs110). La pregunta que quedaría en el ambiente es ¿cómo es posible que ante acciones positivas, los maestros insistan en realizar o continuar con los paros? Lo que mostraría una falta de lógica en el accionar de los maestros, que llevaría a conclusiones como las presentadas por el diario en titulares del tipo «Los profes quieren parar» (HS278), en los que se resalta el «deseo» como motor de las huelgas.

\section{«Parcial paro de educadores en el país» (Hs19)}

Minimizar las actividades de los grupos que no poseen el dominio es sin duda alguna una de las estrategias más utilizadas por los grupos que ostentan el poder y que se interesan por mantener el statu quo. Mediante esta 
estrategia, acciones de gran relevancia y trascendencia se reducen al mínimo y se les niega su eficacia. En los titulares analizados, si bien en algunos casos se emplean cifras que demuestran la cantidad enorme de participantes en las huelgas, estas se contrarrestan con adjetivos que las relativizan o minimizan, incluso así evidencien contradicciones en la información. Un caso paradigmático lo constituye el paro de maestros de 1977 que tuvo una participación considerable en todo el país, o por lo menos así se señaló en innumerables titulares: "7 mil maestros en paro» (HS3), "Paro de maestros en Guajira y Cesar» (HS6), «Paro de maestros en Atlántico» (HS11), «Paro de maestros en Medellín» (Hs12), «Paro de maestros en Caldas» (Hs13), «Se extiende paro de educadores» (HS14), «Disturbios en Medellín» (Hs16), «Disturbios en Barranquilla» (HS17); sin embargo, los periodistas del diario concluyen: «Parcial paro de educadores en el país» (Hs19).

\section{"Miles de estudiantes perjudicados por la falta de maestros en Bogotá»(Cr17)}

En oposición a las cifras presentadas sobre los maestros que minimizan su accionar, el diario El Tiempo, en algunos titulares, desvía la atención de las problemáticas de los maestros hacia los estudiantes y las madres de familia, quienes son presentados como víctimas del accionar de los maestros, y mediante el empleo de la maximización otorga un carácter dramático a los hechos: «Caquetá: 15 mil niños afectados por cese docente» (HS398), «Paro deja sin clases a 20 mil niños en Cúcuta» (Hs372), "Casi 30 mil alumnos aún esperan a su profesores» (HS322) o «Cinco millones de estudiantes se quedaron sin clases ayer» (HS331). Vemos cómo esta estrategia de maximización, acompañada de otra de adjudicación de víctimas al accionar de los maestros, contribuye a crear una imagen negativa en el público lector.

\subsubsection{Aspectos judiciales}

En esta segunda gran temática se analizaron los titulares que se refieren a aspectos judiciales, en su mayoría ubicados en la sección judicial del periódico. Aquí se encuentran titulares relacionados, primero, con maestros judicializados por diversos delitos o maestros víctimas de estos; y segundo, con noticias que se refieren a la muerte de maestros por causas naturales o accidentales. Se identificaron 213 titulares así: Los profesores como víctimas de asesinatos y atentados (75), de amenazas de ataque o secuestro (43), y profesores como agentes de acciones delictivas (53). Respecto a los maestros muertos de modo natural o en accidentes aparecen (18) titulares. Además, en este tema incluimos otro tipo de titulares de análisis al respecto del tema y acciones para la protección de maestros (24). 
«Desaparece profesor» (A)10). «Asesinatos», «desapariciones» y «muertes» de maestros.

El asesinato de maestros en todo el país ha sido una práctica delictiva generalizada a lo largo de la historia. Según las estadísticas de Fecode (www.fecode.edu.co/descargas/educadorcol/boletin_ec_n8.pdf), desde la década de 1980 hasta la actualidad, son más de 650 profesores asesinados y centenares sometidos al desplazamiento. Las estadísticas revelan cifras como las siguientes:

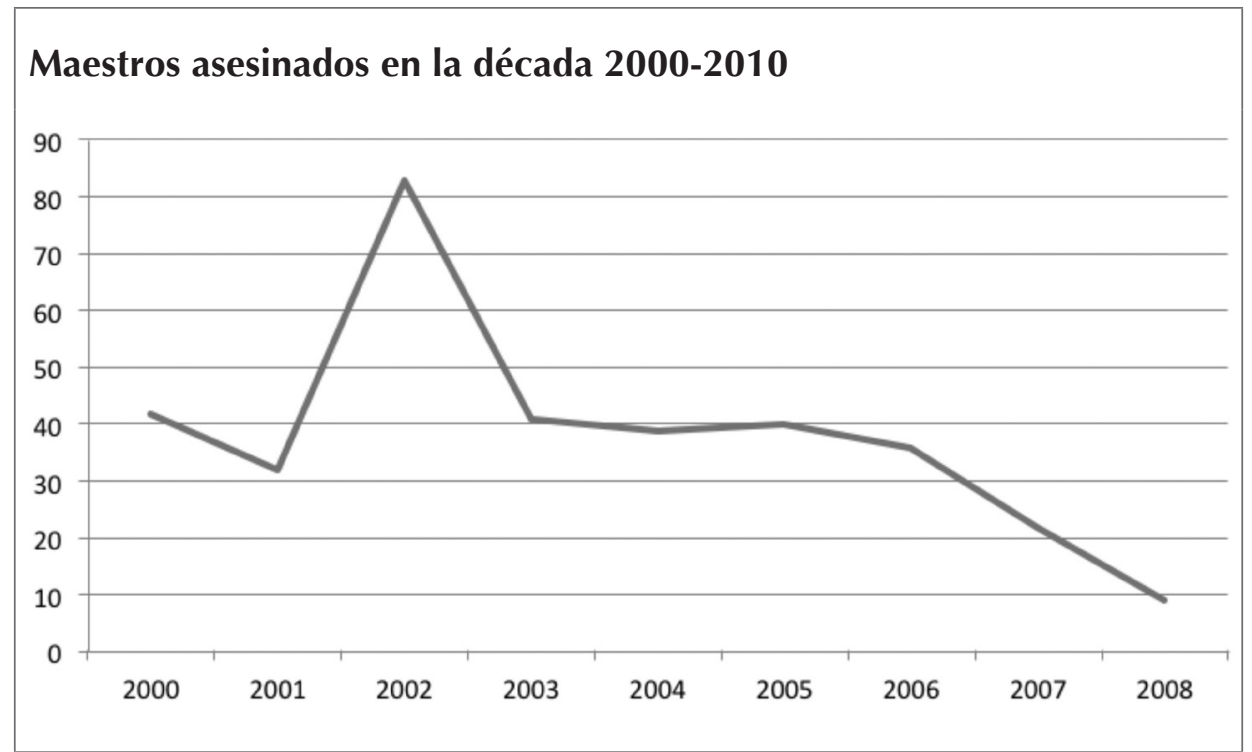

Gráfica 2. Asesinatos de docentes 2000-2008, según FECODE.

Sin embargo, este tema parece poco importar al diario El Tiempo. En el total del corpus analizado aparecen tan solo 76 titulares sobre el tema, que permiten ubicar los grandes periodos en los que se ha generalizado esta práctica o se ha disminuido. Lo que conduce a hablar de una invisibilización, en el diario, del tema de los asesinatos de maestros.

\section{"Muerto educador y herida su esposa» (AJ79)}

Lo más preocupante respecto a la redacción de las noticias de este tipo es que el diario, como ha venido sucediendo también respecto a la responsabilidad de los crímenes a nivel legal, no suele señalar los responsables de las acciones o lo hace de manera selectiva. En términos generales, no se menciona. Tan solo 11 de los titulares presentan los responsables: la guerrilla (4), alumnos (3), sicarios (2), policía (1), secretario (1). El resto no hace alusión a los agentes de los asesinatos. El Estado, presunto responsable de gran parte de estas muertes selectivas de profesores sindicalistas 
o militantes de partidos de izquierda, no se menciona en los titulares. Sin embargo, cuando la guerrilla es la responsable sí se señala, como cuando titulan «Guerrilleros asesinaron a maestra en Cimitarra» (AJ57) o «Guerrilla mató a educadores» (AJ185).

De igual manera, los verbos elegidos para señalar estas acciones en algunos casos son problemáticos; si bien la mayor parte de los titulares hablan de asesinatos, también son frecuentes verbos como «muerto», que obliga a ir al interior del artículo para comprobar si se trata de muerte natural o provocada, o verbos similares, como el caso de «desaparecer», que en titulares como «Desaparece profesor» (AJ1), dan la impresión de que la acción es efecto del mismo agente y no de agentes externos.

Otra manera recurrente del diario de titular el asesinato de maestros, tiene que ver con la escenificación de la noticia, donde el hecho como tal pierde relevancia ante el contexto. Se encuentran así titulares del tipo "Mataron al profe frente a 35 alumnos» (AJ135), «Asesinan maestra frente a 42 niños» (A)184) o "En plena clase asesinan a profesor de primaria» (AJ115). Y, como es de suponer, estas muertes no se investigan y el diario hace eco de esto: tan solo 7 titulares señalan la existencia de investigaciones o detenidos por los asesinatos.

«Maniático sexual nombrado maestro oficial de niños» (AJ2). Maestros que cometen actos delictivos y son judicializados.

En esta categoría encontramos (51) titulares. Hablan de maestros judicializados, detenidos, destituidos o capturados (14); de maestros tramposos, que cometen fraudes o estafadores (8); de violadores (5); de violentos (2); de asesinos (4); de terroristas (2), con lo que el diario construye y refuerza una imagen negativa de los maestros.

El Tiempo señala con claridad en sus titulares la responsabilidad de los maestros en actos delictivos, incluso cuando se trata de personas que habían sido profesoras, que en algún momento ejercieron la profesión, pero ya no lo hacen. Se leen titulares como «9 años de cárcel a ex profesor» (AJ6), en los que no se sabe cuál fue el crimen, pero el hecho de ser ex docente hace que el suceso sea noticiable, como en el caso de «Terrorista herida llevaba doce años como educadora» (AJ33). Sin embargo, resulta interesante que no se referencian las profesiones de otras personas que cometen crímenes.

Cuando el maestro es el agente, no el paciente de hechos violentos, el diario presenta de manera descarnada las noticias para crear impacto en la audiencia: «Profesor ebrio mató a un niño e hirió a 2 personas» (AJ37), 
«Capturados maestros por masacre»(AJ167) o «Sancionan a profesor que violó una niña» (M68).

«Extraña muerte de un profesor» (AJ39).

Maestros fallecidos por causas naturales o accidentales.

Paradójicamente, el diario presenta noticias en las que acontecen hechos naturales que, sin embargo, son noticiables en algunos casos por la identidad de la persona que muere - un profesor destacado- o por las circunstancias: accidentes de tráfico, intoxicaciones, emoción o, como ellos las denominan, «muertes extrañas».

A este respecto es importante resaltar que, al confrontar el titular con el cuerpo de la noticia, se evidencia que se trata de suicidios o incluso de asesinatos violentos, en los que no queda claro por qué se titulan los hechos como «extrañas muertes». Parece que cuando los periodistas asumen que no se trata de asesinatos cuyos responsables son fuerzas del Estado u otros organismos como la guerrilla o los paramilitares, titulan «extrañas muertes» o «muertes». De esta manera, a hechos relevantes se les quita o niega importancia, se les trivializa.

\subsubsection{Salarios de los maestros}

En esta tercera gran temática encontramos 188 titulares que desarrollan fundamentalmente cuatro grandes tópicos: pagos (56); reajustes salariales realizados y proyectados (39); cifras presupuestadas para los pagos (32); no pago de los sueldos a los maestros (26); y otros (35).

Sin embargo, respecto al tema de los sueldos y su aparición en los titulares del diario El Tiempo, surgen algunos interrogantes: ¿por qué este es un hecho noticiable?, ¿qué de particular hay en este hecho que lo hace de interés nacional?, ¿por qué no es noticia cuando se trata de otros gremios? Parece que el presupuesto asignado por el gobierno para el pago de maestros y lo que este representa en términos económicos para el país es, sin lugar a dudas, tema de interés, aunque no sucede así, por ejemplo, con el presupuesto de las fuerzas militares.

Aquí se encuentran titulares que hablan de un hecho que va a ocurrir, que ocurrió o que está ocurriendo. Muchos de los titulares mencionan que en un futuro próximo se pagará a los maestros, que se pagó a los maestros o que «hoy» se paga a los maestros. Sin embargo, algunas de las promesas de pago se incumplen y los maestros entonces toman medidas como irse al paro o no entregar calificaciones a los estudiantes, entre otras. 
«Maestros reciben 26 primas anuales» (sL66).

Los salarios de los maestros constituyen uno de los temas sensibles para la opinión pública. Para el común de la gente, los maestros ganan mucho, tienen demasiados privilegios y trabajan poco. Aunque estas ideas no provienen únicamente de los medios de comunicación, sí ayudan a reforzarlas. El diario El Tiempo, de manera recurrente y sin mayores detalles, informa sobre reajustes a los sueldos de los maestros, así sea simplemente señalando la intención del Gobierno de hacerlo. Hecho que podría crear en el lector desprevenido y poco informado la idea de que los maestros reciben un tratamiento diferente al resto de los trabajadores, quienes solo tienen un aumento salarial al año. Esta imagen de profesor bien remunerado, sin embargo, se contrapone con una realidad en la que ellos son los profesionales del Estado peor pagados.

\section{«El Estado pagará 15 mil millones a los maestros»(st123).}

Presupuesto asignado para el pago de maestros.

Este tópico refuerza el anterior al mencionar cifras cuantiosas, o por lo menos que así lo parecen, en la medida en que se habla de miles de millones y no hay punto de comparación con presupuestos asignados a otros gremios. El lector de la noticia no puede, en principio, saber si esto es lo normal; si se trata de una cifra adecuada o si, por el contrario, es menor que lo requerido, lo que en efecto sería lo que pasaría.

«Gobierno garantizó pago de deudas a 2.200 educadores» (sL124). Falta de pagos a los maestros.

Algunos de los titulares mencionan que el gobierno no ha cancelado los sueldos de los maestros o que les adeuda primas o prestaciones, aunque pocas veces se asocia esta temática con la de las huelgas, y en ningún caso se mencionan las causas del no pago. Se recurre con frecuencia al señalamiento de promesas en los titulares, pero pocas veces se señala su incumplimiento.

\subsection{4 "Maestros, ja estudiar!" (AA.10).}

\section{Actividades académicas de los maestros}

En esta cuarta temática se encuentran 102 titulares que engloban asuntos relacionados con la capacitación de maestros, la evaluación y la realización de actividades académicas del tipo foros, congresos, plenos y otros. 
«Necesidad de preparar a los maestros» (AA98). Capacitación.

En el corpus analizado encontramos 48 titulares que se refieren al hecho de que los maestros se capacitan o deben capacitarse. La mayor parte son titulares que informan que se abren programas de capacitación para maestros en diversos temas: filosofía, educación ambiental, sexualidad, derechos humanos, computación; gran parte se refiere a la capacitación de los maestros en el área de inglés. Otros pocos titulares solo mencionan que los maestros deben capacitarse o cuestionan el hecho de quién enseña a los maestros o cómo debería realizarse esta enseñanza.

«Maestros, ¡al tablero!»(AA93). Evaluación.

La evaluación es un tema polémico dentro del gremio de los maestros, quienes lo cuestionan y no siempre lo aceptan, pues parecería que no se hiciera con fines académicos, con el ánimo de detectar falencias y corregirlas en pro de la educación, sino por el contrario, para estigmatizarlos y, en últimas, desmejorar sus condiciones laborales en términos salariales.

Bajo este rótulo se encuentran en el corpus 31 titulares que en general informan sobre el hecho de que los maestros serán evaluados (17), seguidos por titulares que señalan que una vez realizada la evaluación los maestros «se rajan» (6), y que no quieren ser evaluados (3), que el proceso de evaluación se realiza con dificultad (3), que hay división entre los maestros frente al tema (1) y que los maestros no «se rajan» (1).

«Congreso de educadores» (AA3). Actividades académicas de los maestros.

Los maestros no solo son paros y huelgas, como los presentan los medios. También hacen cosas positivas, se reúnen, discuten, debaten y hacen propuestas; sin embargo, esto parece ser de poco interés noticioso. De hecho, en el corpus analizado tan solo aparecen 22 titulares que se refieren a estas otras actividades de los maestros y que quizá son mucho más importantes que las mencionadas hasta aquí.

El corpus analizado muestra que fundamentalmente las actividades que El Tiempo destaca bajo este tema se relacionan con encuentros académicos como congresos, reuniones, plenos, cumbres o foros. Unos pocos titulares refieren muestras artísticas producidas por los maestros, o sus reflexiones sobre la educación.

Sin embrago, en general, en la presentación de estas noticias, el diario tematiza la acción de los agentes del gobierno en titulares como «Convoca- 
dos los maestros a cursos de capacitación» (AA12). Pocas iniciativas propias de los maestros se señalan, y se resalta más el deber o las carencias intelectuales de los maestros: «Profesores, al colegio» (AA42) o «Inglés, profesores van de regreso a la escuela» (AA92). Aunque el hecho más importante de resaltar es la poca visibilidad del quehacer académico del maestro representado en la prensa. 102 titulares en 30 años resulta una cifra bastante pobre, si se tiene en cuenta la proporción de las otras temáticas que tienen acogida en el diario y que construyen una imagen negativa de los maestros.

\subsubsection{Leyes, estatutos y reglamentos}

Este es el quinto tema en recurrencia en los titulares del diario El Tiempo sobre los maestros y sus acciones. En él aparecen 94 titulares que fundamentalmente tratan sobre el estatuto docente (38), tópicos relativos a decretos, leyes o reformas que reglamentan la profesión docente (27), el escalafón docente (18) y acciones legales emprendidas por los profesores contra las leyes, como es el caso de las tutelas (6).

Como se nota, en general, estas temáticas aparecen en los periodos concretos en los que se crearon estatutos o en los que se modificaron o decretaron leyes de educación. Los dos grandes tópicos incluyen el Estatuto docente de 1979 y la Ley general de educación de 1994. Se mencionan sus aprobaciones, el debate que generaron y la demanda de éstos por el gremio de educadores. Los titulares se orientan hacia el señalamiento de prohibiciones o sanciones, más que hacia los derechos de los profesores. Se señala, por ejemplo, la prohibición a la solicitud de permisos «Según el Consejo de Estado: maestros, sin derecho a permisos sindicales» (LY91); la prohibición a participar en política: «Dice Mineducación: Los maestros no pueden participar en política; tribunal decide situación» (AO42); la prohibición a los ciegos de enseñar: «El nuevo estatuto docente prohíbe a ciegos enseñar» (เy8). También las noticias señalan las sanciones que se desprenden de la aplicación de estas legislaciones: «Las sanciones a los maestros serán más drásticas» (LY74), «Sanciones por incumplimiento de normas del Estatuto docente» (LY76), «Suspenden a maestros inmorales. Se reformará el Estatuto Docente» (M67).

Tal como señalan Carbonell y Tort (2007, p. 63), en los titulares se da protagonismo fundamentalmente a los agentes del Estado; son ellos quienes ejercen el poder como autoridades. Sus actos son declarativos: «dicen», «señalan», pero pocas veces explican los alcances de las leyes y sus repercusiones en las prácticas cotidianas de los maestros, excepto, como ya se dijo, para señalar prohibiciones. Las voces de los maestros, los directamente implicados, rara vez se escuchan; no se exponen sus cuestionamientos 
a las leyes o su análisis. Se presenta una voz que debe acogerse dada su legitimidad.

Con frecuencia, los titulares relativos a estatutos y leyes aparecen en continuidad con titulares sobre el escalafón docente, pero no se señala de manera directa su relación. Los titulares al respecto son demasiado generales, incluso algunos solo incluyen preposiciones como «Con el escalafón» (ıY17) o más generales aún: «El escalafón» (Ly27), o mencionan simplemente plazos para asimilarse al escalafón. No se habla de las causas y consecuencias de la promulgación de estas leyes y sus implicaciones directas en los sueldos de los maestros.

\subsection{6 «Gobierno condecora a educadores» (RC1). Reconocimientos.}

En este tema encontramos 83 titulares que se refieren a la celebración del día del maestro, a diversos premios a los mejores educadores y al reconocimiento a la labor de algunos educadores particulares.

Así, pues, en general, la construcción de estos titulares es recurrente; en ellos se resalta una acción: la celebración; unos actores: el gobierno; una fundación o entidad que entrega el premio; y, en último lugar, el homenajeado: el maestro. Pocos son los titulares que mencionan en primer término al maestro y con nombre propio. Algunos titulares hablan de los maestros en general y otros se refieren a maestros específicos, en su mayoría maestros o maestras recordados por su labor y carisma. Gran parte de estos titulares en realidad forman parte de la sección «Correo» de El Tiempo, en la que personas particulares recuerdan personas particulares: los maestros. Algunos titulares se refieren en términos afectuosos a los maestros, por ejemplo con el diminutivo «profe» y mediante calificativos como «mi querido profe». A diferencia de los temas analizados hasta el momento, aquí se resaltan valores de los maestros y se les recuerda con gratitud y aprecio.

\subsection{7 «Un burro se come nómina de maestros» (CU3). Curiosidades y otros asuntos.}

Bajo este rótulo se incluyen titulares que informan sobre hechos poco comunes, risibles o curiosos. Así aparecen 21 titulares variopintos y sin igual. Por ejemplo, se señala que la NASA recluta docentes, que hay una profesora de doce años de edad, que Coquito nació de la idea de un profesor francés, que un burro se comió la nómina de los docentes, que un profesor que no sirvió de profesor de música fue nombrado rector, que pagarán los sueldos 
de los maestros con un bingo, que se importan técnicas de enseñanza nipona y profesores cubanos, etc.

\subsection{8 «Entregan viviendas a maestros»(BS4). Programas de bienestar social para docentes.}

En esta temática aparecen 16 titulares que se refieren a proyectos creados por distintas instituciones para el bienestar de los maestros, fundamentalmente para solucionar el problema de vivienda. Aparecen también titulares que cuestionan los servicios médicos ofrecidos al gremio. En la mayor parte de estos titulares, los maestros aparecen como beneficiarios de programas.

\subsection{Los actores de la agenda periodística educativa: maestros, representantes del Estado y agremiaciones de maestros}

Como lo señala el epígrafe presentado al inicio de este acápite, «el individuo es considerado por el sistema de información de acuerdo con su rol social»(Rodrigo, p. 2003): a mayor popularidad y relevancia social, mayor notoriedad en los medios.

El diario El Mundo publica cada año los 25 personajes más conocidos en los distintos ámbitos sociales. Para el caso de la educación señala que «el top de la educación» en 2005 lo constituían 10 políticos, cuatro rectores de universidad, cuatro catedráticos de universidad, dos representantes de la patronal de enseñanza privada, dos representantes de los sindicatos, un representante sindical estudiantil y un profesor de secundaria (citado en Carbonell y Tort, 2006, p. 26). Si hubiera un equivalente de esta encuesta en Colombia, quizá las estadísticas variarían un poco en cuanto a los rectores y profesores universitarios, pero no en cuanto a los primeros y los últimos de estos actores sociales de la educación. Los primeros serían políticos y los últimos maestros, si es que se presenta este último.

El diario El Tiempo trata de manera diferenciada a los actores educativos. Los políticos o administrativos de la educación tienen derecho a la identidad, se los referencia con sus nombres propios y cargos; los maestros son representados en masa, seres anónimos. Los representantes sindicales se mencionan bajo la denominación colectiva. Pero lo más interesante del análisis es ver cómo se los representa, qué características se les atribuye. Pero antes veamos algunas estadísticas de su aparición en los titulares. 


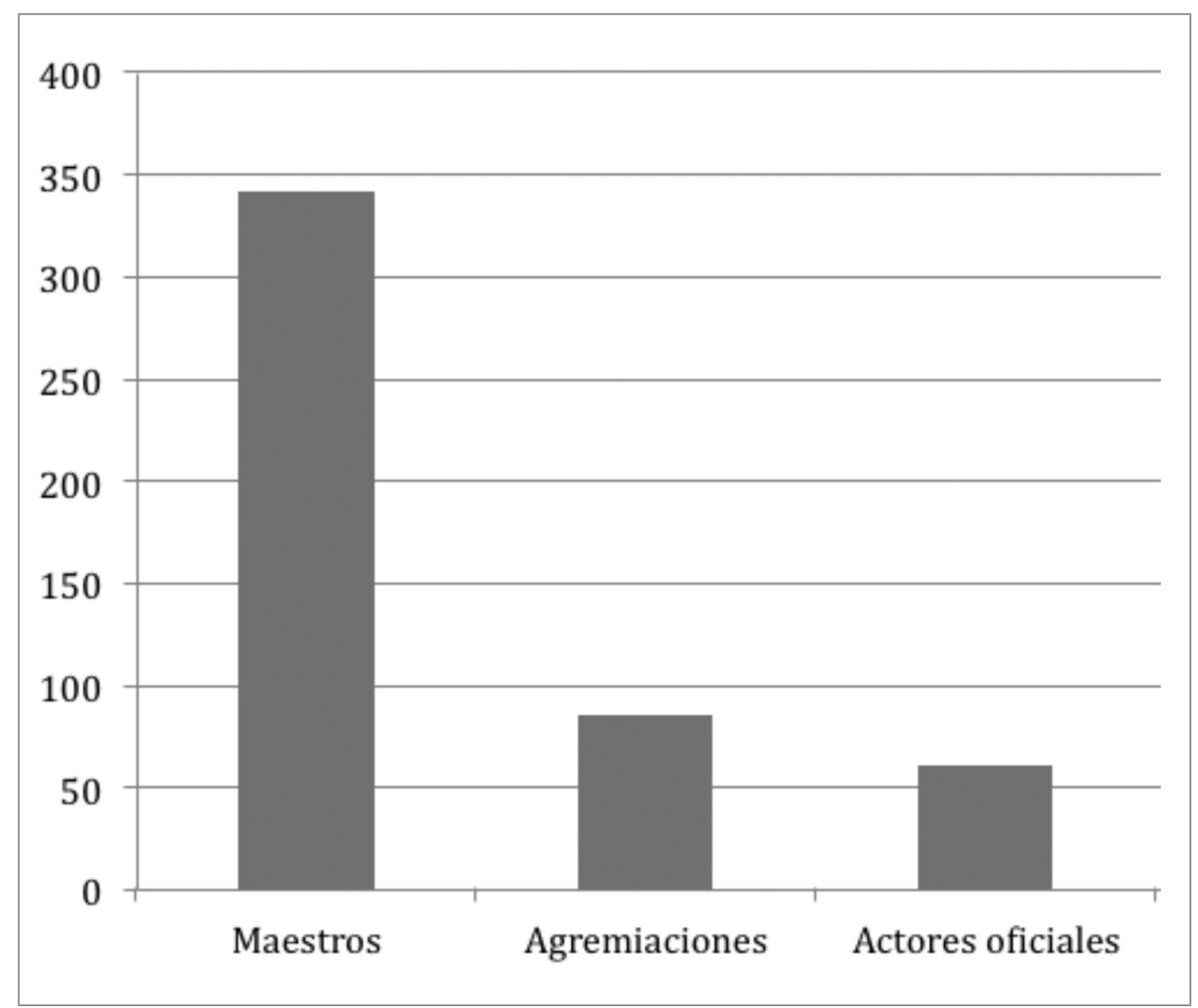

Gráfica 3. Frecuencia de aparición de actores sociales

\subsubsection{Los maestros}

En esta categoría se analizaron los titulares cuyo protagonista es el maestro como tal, que permiten formarse una idea de él, con sus cualidades o defectos y su accionar.

En general, en esta categoría, la mayor parte de los titulares analizados se refiere a los maestros en términos negativos; solo unos pocos señalan aspectos positivos. Los demás se centran en el deber ser: ese maestro ideal que a la sociedad le gusta construir y al cual le atribuye características particulares opuestas a ese maestro que es, el de carne y hueso.

\subsubsection{Atributos de los maestros}

Maestros piratas, falsificadores, locos, homosexuales, politizados, ladrones, abusadores, etc.

Como lo indican las cifras, son más los aspectos negativos que se resaltan de los maestros que los positivos, así son cuestionados desde todos los 
puntos de vista posibles: profesional, social, ideológico, personal de tipo moral, o incluso por la identidad de género.

Calificativos de tipo profesional. Parte de la imagen negativa que circula en la sociedad respecto al maestro tiene que ver con el cuestionamiento a sus habilidades y compromiso con el trabajo, los cuales suelen ponerse en duda. El diario El Tiempo presenta a los maestros como carentes de imaginación (M13), malos profesores (M34), nada ejemplares (M115), con pocos conocimientos (M180), ausentistas (M62) o piratas (M39), que trabajan poco (M28).

Calificativos de tipo social. Según el diario, los maestros son poco colaboradores (M61), peligrosos (M85), ladrones (M82), traficantes (M8), falsificadores (M190), culpables de las crisis (M5), despilfarradores (M9), mal enseñados (M136), careros (M46), divididos (M2), homicidas (M65) o problemáticos (M91) y por sus acciones incorrectas son denunciados (M49), sancionados (M68, M71, M78, м140) o destituidos (M39, м63, M98, AJ50, АJ187). Esta imagen social del maestro también se intensifica si se relaciona con los profesores que amenazan (Hs2, HS31, Hs57, Hs65, Hs76, Hs165, Hs264, Hs273, Hs445, hs494), construida bajo la temática de Huelgas, paros y ceses laborales.

Calificativos personales. Aquí encontramos diversos órdenes: los referidos a aspectos morales, en los que al maestro se califica de tramposo (M190), inmoral (M67, AJ64), abusador sexual (AJ80, M68, M69, M83), o «demasiado vivo» (M73); los referidos a la identidad sexual del maestros cuestionan fundamentalmente a los maestros homosexuales (м82, м167, м170, м172); los referidos a la salud mental de los docentes señalan la locura de los maestros (M129, м213, м214); también algunos titulares cuestionan su derecho a participar en política y a tener diversas ideologías, como en el caso de los profesores masones (M207), los profesores «politizados» (M20, M54, M74, AO43) o sindicalistas (M182).

Maestros importantes, de mente abierta, bien conectados, creativos, inocentes, felices... Representación positiva. De la misma manera que se analizaron los anteriores calificativos, aquí se presentan algunos de los calificativos positivos que se refieren a los maestros.

Calificativos profesionales. Los atributos que se señalan como pertenecientes a los maestros, en realidad no son demasiado dicientes; algunos indican su carácter innovador (M77), su creatividad (M126), su preocupación por la calidad de la educación (M211), su mente abierta (M202), su calidad de buen profesor (M189), su carácter trabajador (M94). 
Calificativos sociales. Este aspecto resalta que algunas de las cualidades señaladas se refieren a casos particulares, como cuando se menciona a un maestro gobernador (M81), a maestros liberales ( 1 109) o que cumplen (M118).

Calificativos personales. A diferencia de los calificativos negativos del apartado anterior, que eran claros y concisos, los presentados aquí son muy generales - de nuevo-y no destacan aspectos morales de los maestros; tan solo se señala su felicidad ( 1445$)$, paciencia ( 1 144), esperanza (M37), mente abierta (M202) o inocencia (M200). También se habla de maestros elegibles (м92), haciendo alusión a su posibilidad de participar en política.

\subsubsection{Los maestros: cifras y estadísticas}

Otra forma bastante frecuente del diario para referirse a los maestros, es la despersonificación mediante el proceso de cuantificación. Así, el maestro anónimo pierde sus características como persona y se convierte simplemente en una estadística más. Bajo este tema se encuentran 124 titulares que, en términos generales, se refieren a los maestros como cifras, números o estadísticas. Mencionan el déficit de maestros en el país (57), la cantidad de concursos o plazas para ser ocupadas por maestros (55), o el superávit de maestros (4), entre otros (12).

En general, se habla de la falta de maestros en el país; se menciona un déficit de maestros en el que se señalan cifras. Se resalta el hecho de cómo pequeñas poblaciones carecen de profesores y los solicitan al Gobierno. En algunas ocasiones se cosifica aún más al maestro, y se le señala como un bien común más. Aparecen titulares tan insólitos como «Sin maestros, sin veterinario... y sin tractor» (CF37) o «Profesores, transporte y vías, pide la Gran Yomasa» (CF19). Titulares que permitirían cuestionar seriamente la lógica de los redactores al establecer categorizaciones.

Por otra parte, y de manera contradictoria, se leen titulares que hablan de un exceso de profesores en el país. Igualmente aparece una considerable cantidad de titulares que se refiere a concursos docentes que se abren y se cierran, y al presupuesto asignado para tal fin. De nuevo se mencionan cifras considerables y se señala cuánto cuesta el gremio de los maestros a la nación, pero no se señalan los beneficios.

\subsubsection{Los actores oficiales: políticos y administradores de la educación}

En el diario El Tiempo no solo aparece la voz de los redactores, sino que se escuchan otras voces que se pronuncian respecto a los maestros y sus 
acciones: el Ministerio de Educación Nacional (MEN), la Secretaría de Educación, los ministros de Educación e incluso los presidentes de turno.

\section{Representaciones positivas}

De los 50 titulares en los que se habla de las acciones de los organismos del Estado frente a los maestros, la mayor parte se refiere a acciones positivas de esos organismos (30). A diferencia de su representación de los gremios, el diario señala que el Estado «dialoga», «invita a participar», "se preocupa por», "hace llamados», «se reúne», «apoya», «asume», «establece contacto directo»y «responde» a las peticiones del magisterio. Todas, como vemos, son acciones positivas y loables, aunque también, como se esperaría de él, en ocasiones se «endurece», «da ultimátum» y «niega acciones».

\section{Titulares neutros}

La otra serie de titulares respondería a lo que denominamos titulares neutros, que informan y tratan de hechos del decir de estos organismos, aunque también a diferencia de lo que se predica de los gremios de maestros, aquí se dicen o se piden cosas positivas: se anuncia que hay garantías para el diálogo, que se dignificará la profesión docente o que no hay motivos para las huelgas y se pide responsabilidad, lealtad, ayuda a los maestros.

\section{Titulares negativos sobre los organismos del Estado}

Tan sólo se publican dos titulares en los que se señalan acciones negativas de estas instituciones y personas: uno que se refiere a tráfico de influencias para nombrar maestros por parte del secretario de Educación y otro en que se señala una investigación de las medidas tomadas por la Secretaría de Educación.

\section{Titulares negativos sobre los maestros en boca de los representantes del Estado}

En ocasiones la voz institucional se presenta para construir una imagen negativa de los maestros. Así, aparecen titulares en los que los responsables de la educación se refieren a los maestros para señalar que éstos «envenenan a los niños», «envenenan sus almas», «chantajean» al gobierno o son «inmorales»; también hay titulares que refuerzan la idea de que los maestros no son seres autónomos, profesionales y competentes, sino que hay que educarlos ya sea de manera directa o mediante la implementación de manuales para educadores. Incluso, contrario a lo mencionado ante- 
riormente respecto a la falta de maestros en el país, el gobierno señala que sobran maestros.

\subsubsection{Los colectivos de maestros: FECODE y ADE.}

En torno a estos protagonistas aparecen 85 noticias que se pueden clasificar en titulares que señalan aspectos negativos, positivos o neutros de estos colectivos.

\section{Representaciones negativas}

Las agremiaciones se asocian a acciones negativas de diverso orden, como proselitismo político, amenazas de paro, ataques, deficiencias, rechazos, negaciones o descontento (17). También se presentan como organismos con problemas internos: divididos, con pugnas internas y en crisis (8). Un titular incluso habla de «La educación vs FECODE» (AG69), en el que de alguna manera se puede resumir la imagen que proyecta el diario sobre la relación entre estos dos organismos. En ocasiones da la impresión de que la relación entre las agremiaciones y la educación, o mejor, los estamentos oficiales que la rigen, está planteada en términos de la metáfora de la guerra, como se percibe en el titular anterior y se enfatiza en la cantidad de titulares que hablan de «ataques» de FECODE, «amenazas», o el «estado de alerta» en el que, según los periodistas, se encuentran las agremiaciones.

\section{Representaciones positivas}

En realidad, tan solo seis titulares mencionan aspectos positivos de las agremiaciones de educadores: uno señala que FECODE «tiene razón»; tres reconocen la unión de los sindicatos de educadores; y dos titulares, en apariencia positivos - «Gracias, FECODE»- y que forman parte del editorial de El Tiempo del 14-9-89 y el 17-9-89, en realidad son todo lo contrario: mediante la ironía dan las gracias a FECODE con su falta de sentido patrio al llamar a paro en un momento de crisis del país. Por lo que en realidad los titulares positivos aparecidos en El Tiempo sobre los gremios de educadores se reducen a cuatro.

\section{Titulares neutros}

Aquí presentamos dos divisiones: una serie de titulares que simplemente informan de actividades realizadas por las agremiaciones, sin ninguna valoración particular, incluso de carácter bastante general (39), en donde se habla de reuniones de FECODE o de la ADE, de elecciones, y una gran parte simplemente señala acciones del «decir», como denunciar, responder o 
pedir; acciones que sin embargo no dejan de tener ciertos rasgos negativos, como se analizará más adelante.

La otra serie de titulares que consideramos neutros, pero que seguramente para la opinión pública y el lector en general no lo son tanto -sobre todo si se tiene en cuenta la imagen negativa predominante en la representación de los maestros en el diario- se trata de aquellos en los que se relacionan las agremiaciones con huelgas y ceses de actividades (7). Según nuestro criterio, la huelga es un derecho de los trabajadores y no tendría por qué verse como algo negativo. Es un derecho consagrado en la Constitución Nacional y en los convenios laborales internacionales.

\subsection{La ubicación de la noticia en el diario}

Si como señala Giró, «la política o línea de gobierno se define en el editorial, las portadas, los titulares y en la selección y ubicación de las noticias» y «los titulares de la portada como los de las páginas interiores son de suma importancia en la jerarquía periodística y tienen una gran influencia en la formación de la opinión pública» (2006, citado en Carbonell y Tort, 2006, p. 14), resulta trascendental averiguar cómo realiza el diario El Tiempo la ubicación de las noticias sobre los maestros y sus acciones.

La primera página de El Tiempo reproduce fielmente lo señalado hasta el momento en el tratamiento de la noticia sobre maestros. La mayor parte de las noticias se refieren a los paros del magisterio, sea en términos generales, en titulares escuetos que simplemente señalan el hecho como «Paro de maestros hoy en el país» (HS53); en titulares -bastante frecuentes- que introducen la valoración del diario frente al hecho como «llegal y parcial, el cese de maestros» (HS67); o en titulares en los que se refuerza la minimización de las acciones de los maestros y su efectividad. Otros titulares, una vez dada la condición anterior, señalan las sanciones que se impondrán a los educadores un poco en términos «amenazantes»: «Sanción a maestros estudia el gobierno» (HS79), «No pagarán a maestros que no trabajen» (Hs285) o «Maestros en paro serían despedidos» (HS447). Como sucedió con el análisis anterior, solo uno de los titulares de primera página menciona la causa de las huelgas. De esta manera el público lector, que se queda solo con los titulares, construye en su mente la idea de que el magisterio realiza huelgas frecuentes pero no reconoce o identifica causas.

Otro tipo de titulares de primera página se relaciona con los salarios de los maestros, aunque como vimos, no se establece relación entre el no pago de salarios y las huelgas. Aunque ha habido periodos de hasta tres o más meses 
en que los maestros no recibieron sus salarios, para el diario El Tiempo esto no es motivo de un titular. Sin embargo, sí se habla de aumentos salariales en titulares del tipo «Entre el 15 y el 30\% reajuste a maestros» (sL34), que dejan el interrogante de por qué a los maestros se les sube más el sueldo que al resto de los trabajadores, o como «Reajuste a maestros será de 25\%» (SL162), o «Aumentan salarios a maestros» (SL48). También se mencionan grandes cantidades de dinero, como «\$2000 millones pagará gobierno al magisterio, por el nuevo escalafón» (SL43), que dejan la sensación de que el magisterio le cuesta mucho al país.

Otros de los campos temáticos de los titulares de primera página se refieren al asesinato de profesores. Aquí también prima la representación ambigua, en el sentido de emplear verbos como «muerto» o «fallecido», que les imprimen un carácter natural; o titulares en los que se desvía el hecho con el ánimo de otorgarle carácter dramático, como «Matan a profesora en frente de sus alumnos» (Aj108) o "Conmoción por crimen de dos alumnos y un maestro» (AJ114). También es importante resaltar que al referirse a los asesinatos de maestros, estos tienen diferente estatus. El diario El Tiempo informa con mayor frecuencia sobre asesinatos de profesores universitarios que de maestros de básica o secundaria, y referencia más asesinatos en ciudades como Medellín y Bogotá que asesinatos en las provincias, lugares donde se comete el mayor número de homicidios. Es de señalar que aunque el diario no suele presentar culpables de estos crímenes, sí lo hace cuando se trata de la guerrilla: «ELN asesina un profesor cuando dictaba su clase» (AJ31).

Otros temas que pueden aparecer en los titulares son aquellos que representan de manera negativa a los maestros, que señalan acciones reprobables ejercidas por estos; algunos ejemplos son: «Acusan a 800 maestros de hacer trampa» (AJ211), «Profesores mal enseñados» (MT135), «Maestros oficiales, al borde de la locura» (M214), «La locura ronda a los profesores» (мT220), «Un maestro nada ejemplar» (M115), «llegales, 11 mil maestros del distrito» (M104). Titulares que en ocasiones se refuerzan en el interior del diario en los editoriales, cuando se señala, por ejemplo: «Maestros de la estafa» (AJ211) o «Prohibido parar» (HS515).

Una de las características más importantes de los titulares de primera página es su relación directa con la oficialidad en oposición a la figura del maestro. Una gran cantidad hace eco de las afirmaciones de ministros de educación, alcaldes o secretarios de educación y destaca el carácter negativo en la representación de los maestros. Únicamente los organismos del Estado tienen derecho a voz en la primera página. Los maestros tan sólo en 
una ocasión vieron reflejada su voz en los titulares: «Nuestra escuela está anquilosada, educadores» (AA31). Este titular tiene, por demás, claro carácter negativo, del cual se desprende responsabilidad de los maestros.

Se leen entonces titulares tan agresivos como "Los maestros "envenenan" a los niños» (AO25), puesto en boca de la secretaria de Educación, titular que paradójicamente aparece parafraseado dos años después, de nuevo en boca de la secretaria de Educación -suponemos que la misma-: «Dice secretaria de Educación: "Hay profesores que envenenan la mente de los niños"»(AO33). Interesante ver cómo el diario privilegia este tipo de información como titular de primera página.

La voz de la oficialidad también se ve reflejada en el diario mediante la referenciación de juicios de valor -siempre negativos- de las acciones de los maestros, en titulares como «El paro de maestros es absurdo e injusto, dice Mineducación» (AO40), "Gobierno dice que no hay motivo para la huelga» (AO14), "Proselitismo político del magisterio censura Turbay» (AO12), o en titulares de clara representación positiva de estos, como «Durán Dussán y su balance. "Me voy satisfecho"»(AO2), "Mineducación dispuesto al dialogo, el gobierno no aceptará el paro de los educadores» (HS270), «El gobierno no se deja intimidar: Rivas Posada» (AO13), «Anuncia Lloreda. Estatuto docente para dignificar la docencia» (LY34), «Afirma Turbay. Estatuto docente, fruto de política avanzada» (LY43).

De esta manera, la tan citada neutralidad e imparcialidad de los diarios se ve claramente cuestionada al evidenciarse una toma de posición a favor de la oficialidad y una representación de los discursos hegemónicos en detrimento de la imagen de los maestros y sus acciones.

Otras secciones. La mayor parte de las noticias sobre los maestros y sus acciones se presenta en el diario en secciones como «Nación», "Información general», «Sección judicial», «Bogotá», «Educación», «Suplementos», «Breves» o «Correo» de El Tiempo. Muchas de las noticias no aparecen en la parte superior del diario, sino en los extremos inferiores en pequeñas secciones. En ocasiones es cuestionable la distribución del espacio que hace el diario, pues por citar tan solo dos ejemplos, una noticia de la importancia de «Un colombiano mejor profesor del año en E.U.» (RC36), no merece un titular en primera página, sino que se ubica en la página última $C$; en cambio, sí merecen portada noticias como «Acusados un profesor y otras 7 personas por crimen de Gloria Lara» (AJ38) o «Capturados maestros por masacre» (AJ167). 
El otro ejemplo lo constituye la notica de una huelga de educadores realizada en 1984 que duró varios días y la posterior decisión de éstos de entrar en huelga de hambre. Noticia que sin embargo no tuvo eco en el diario y se ubicó en la sección «Breves» bajo el título «Retirados por desmayo dos de los maestros en huelga de hambre» (Hs193) y en la parte inferior de la página última B: «En huelga de hambre maestros que se tomaron la gobernación de Boyacá» (hs195). En la misma página también se destaca la noticia de que «Murió envenenado ayer tigre del circo Rolex», que incluso viene de la primera página del diario El Tiempo. Paradójica forma de ver las noticias y su importancia. Que los maestros Ileven varios días en huelga de hambre no es relevante, pero que muera envenenado un tigre sí.

\section{A manera de conclusiones}

A partir del análisis de los artículos del diario El Tiempo, publicados entre 1977 y 2005 y referidos a los maestros, se observó cómo se presenta y construye una imagen negativa de los mismos y sus acciones. La información trasmitida se centra principalmente en el maestro como agente de paros y huelgas. De estos hechos, el diario no menciona las causas, generando así una parcialización que impide la visión total del fenómeno. De igual manera, los periodistas del diario tienden a deslegitimar estas acciones reivindicatorias de los maestros al calificarlas de ilegales y privilegiar titular la información con amenazas de sanciones y castigos a los docentes; reiteran que se trata ya de viejas costumbres del magisterio, que se han convertido en acciones repetitivas y contradictorias al señalar que frente a acciones positivas del Estado los docentes responden con paros. Los periodistas con sus titulares minimizan las acciones de los docentes al señalar reiteradamente que los paros fueron parciales, que no tuvieron el alcance esperado o que fueron un fracaso, lo que paradójicamente no se corresponde con las cifras que presentan, las cuales hablan de cientos o miles de movilizados. Por el contrario, construyen una imagen de maestros victimarios que con sus acciones perjudican a miles de niños que se quedan en las calles o en las que miles de madres sufren al no poder enviar a sus hijos al colegio, esta vez magnificando los hechos.

Al hablar concretamente de los maestros, el diario El Tiempo construye una representación negativa de la imagen de estos. Gran parte de los titulares se centran en las carencias de los docentes como profesionales, se les tacha de faltos de vocación, perezosos o poco imaginativos. Como agentes sociales se les tilda de peligrosos, ilegales, traficantes o falsificadores, entre otros apelativos. Respecto a sus valores morales, se los denomina inmorales, tramposos o mañosos. Además, se les cuestiona su salud mental y tendencias sexuales. Una gran cantidad de titulares, aparecidos casi siempre 
en la sección judicial del diario, reiteran esta imagen negativa del maestro al tildarlo, entre otros calificativos, de delincuente, asesino, violador, ladrón o narcotraficante.

Los titulares que presentan una imagen positiva de los maestros resaltan aspectos como su carácter tecnológico, su creatividad, su compromiso o paciencia. Vale la pena señalar que los adjetivos empleados aquí no son tan contundentes como los que señalan sus aspectos negativos.

Pero también los maestros en Colombia son víctimas de violencia y así lo señalan los periodistas del diario. Sin embargo, frente a las estadísticas alarmantes de asesinatos de docentes en el país, tan solo en contadas ocasiones el diario hace mención de ello. Invisibiliza así las acciones realizadas presumiblemente por agentes del Estado que convierten a Colombia en uno de los países con mayor violencia hacia los grupos de oposición y hacia los militantes sindicales y gremiales. Aquí, de nuevo, la información es parcializada al no mencionar los agentes de las acciones. Paradójicamente, frente a temas como la muerte, el secuestro, amenazas contra los maestros o el desplazamiento -del cual no se halló ni un solo titular-, cuyas cifras en Colombia son de gran magnitud, el diario contrapone noticias en las que notifica de muertes accidentales o curiosas de maestros, trivializando así la información y resaltando lo anecdótico frente a lo recurrente y dramático.

Otra manera de representar a los maestros es relacionarlos con indicadores macroeconómicos, en los que se resalta lo costoso que le resulta al país los salarios de los maestros. Se mencionan enormes cifras, en las que se habla de constantes ajustes salariales a los docentes y de enormes presupuestos, idea que podría contribuir a que los lectores se hicieran una falsa imagen de su realidad salarial. El diario no menciona en sus titulares la educación como un bien público que necesita una fuerte inversión presupuestal si lo que se desea es una formación competitiva de alta calidad mundial y, sobre todo, si en verdad se cree en su poder para transformar la sociedad y las desigualdades sociales. Resulta también interesante preguntarnos qué hace que esto sea una noticia interesante para el lector. Por qué no se cuestionan o se conoce los presupuestos y los salarios de otros gremios u organismos como las fuerzas militares o los parlamentarios colombianos, por ejemplo.

Relacionado con la imagen anterior está el tratamiento de los maestros como cifras. El maestro se cuantifica, se convierte en un simple indicador del que se señala su abundancia o escasez, que por demás siempre es contradictoria. Unos días se dice que hay déficit de maestros y otros -la mayoría- se dice que hay exceso. Se reitera el tema de los costos de los maestros, pero en ninguna se señalan los beneficios que ofrecen al país. El maestro es presentado como una masa anónima y uniforme, en la que no caben 
las individualidades y donde sus subjetividades se anulan en beneficio del colectivo.

Los maestros también aparecen relacionados con asuntos legales, más concretamente con la promulgación de nuevas leyes o decretos que los cobijan. En estos titulares, sin embargo, se privilegia el hecho legal y poco se resalta cómo se verá afectado el maestro por estas acciones. En ocasiones se señala el carácter problemático de las leyes, pero casi siempre aparecen presentadas de manera general, lo que impide dar cuenta del malestar generado entre los maestros y los acalorados debates suscitados debido a sus repercusiones salariales y de profesionalización docente. Estos hechos no aparecen en los titulares del diario. El maestro se presenta básicamente como un actor social con más deberes que derechos. Los titulares resaltan las prohibiciones de las leyes y las sanciones que se generan a partir de ellas.

Para el diario El Tiempo, los maestros son visibles y motivo de celebración solo durante el día del maestro: el 14 de mayo. Durante esta fecha se les recuerda y se menciona fundamentalmente el homenaje que se les brinda mediante diversos premios. Resulta sin embargo paradójico que el maestro aparezca en estos titulares como beneficiario de acciones producidas por el gobierno, por fundaciones o como producto del recuerdo particular de algún periodista o personaje famoso. Son éstos quienes aparecen en primera instancia como agentes de acciones positivas. Aunque es de resaltar que en la sección "Correo» de El Tiempo, varios individuos reconocen y recuerdan a sus maestros y se refieren a ellos en términos positivos.

Las agremiaciones de maestros, en particular FECODE y la ADE, tampoco escaparon de la representación negativa del diario. Estos organismos se muestran como entes divididos, con problemas; generadores de acciones negativas como paros, huelgas, amenazas, ataques, etc. Solo cuatro titulares resaltan aspectos positivos, y una buena cantidad simplemente informan sobre sus acciones: reuniones, asambleas, votaciones, debates, etc.

La voz de los organismos del Estado y sus acciones también aparecen en el diario, pero, por el contrario, aquí la representación que se hace de ellos es bastante positiva. La mayor parte de los titulares señala que el gobierno dialoga, invita, apoya, reúne, se preocupa o hace llamados. Tan solo dos titulares señalan acciones negativas del Estado. Pero los periodistas, al dar la voz a los entes del Estado en sus referencias a los maestros, también contribuyen a construir una imagen negativa de los docentes. Se señala por ejemplo que cierta secretaria de Educación afirmaba que los maestros «envenenan» a los niños y sus almas, que chantajean al gobierno o que son inmorales. 
Pocos titulares señalan de manera directa acciones positivas de los docentes. Algunos se refieren a capacitación de maestros o a actividades académicas realizadas por estos, como congresos, eventos, plenos, cumbres o foros.

La temática de huelgas o paros, que constituye la noticia de mayor frecuencia en el diario, adquiere matices importantes con el paso de los años debido a la construcción discursiva que se realiza a través de los mecanismos legislativos y el eco que obtienen en el diario El Tiempo. Poco a poco se fue construyendo la idea de la ilegitimidad de estas acciones por parte de los maestros, las cuales, aunque están consagradas en la ley, por las continuas amenazas y los hechos concretos de sanciones y descuentos salariales se han ido reduciendo cada vez más hasta el punto de que ahora, con mayor frecuencia, ellos se abstienen de participar en los ceses laborales. Así, lo que antes era parte del habitus de los maestros, se ha ido perdiendo. Éstos cada vez marchan menos y participan menos en actividades convocadas por sus agremiaciones. Los maestros de la calle desaparecieron y cada vez concentran más sus acciones en el aula, donde han sido acorralados.

Un hecho importante de resaltar es el cambio progresivo en relación con los docentes y lo noticiable. Con el paso de los años, los maestros y sus acciones han dejado de aparecer en el diario El Tiempo. Veamos algunas estadísticas:

\section{Frecuencia de noticias de maestros en el diario}

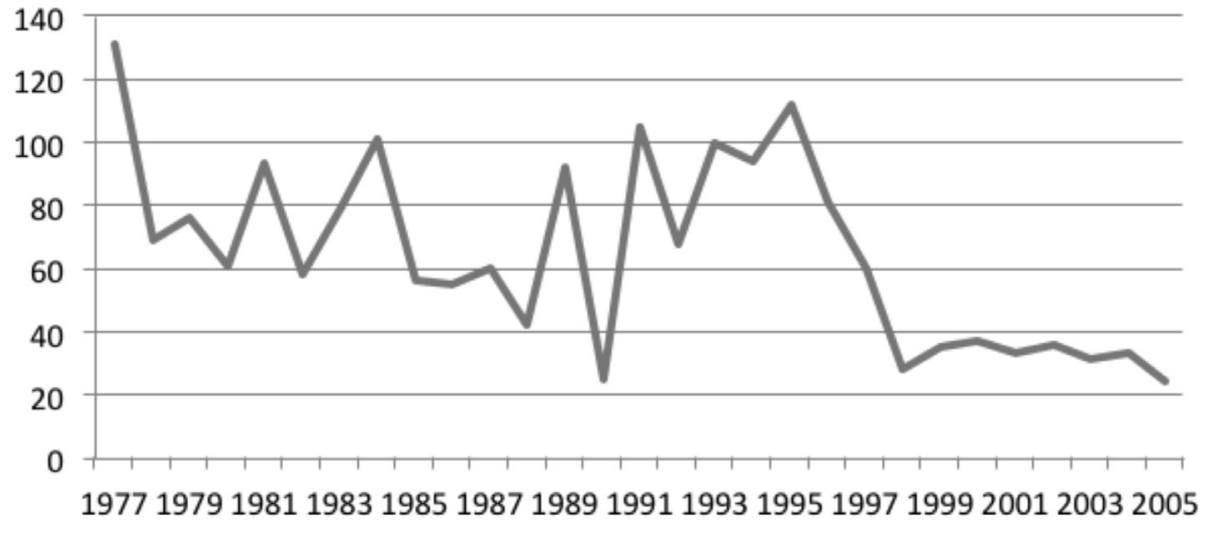

Gráfica 4. Frecuencia de noticias de maestros en El Tiempo 
Obsérvese que desde finales de los años de 1990, el diario El Tiempo presenta una reducción considerable en el número de noticias relacionadas con los maestros. Esto se explica fundamentalmente por las acciones del gobierno, que terminaron por acabar sus huelgas. La ministra de Educación María Cecilia Vélez, al amenazarlos con sanciones y al tocar uno de sus aspectos más sensibles -el factor económico, realizando descuentos por cada día de paro y afectando sus prestaciones labores-, acabó con el derecho del trabajador a la huelga. Y al acabarse ésta, también se acabaron las noticias de reinicio de clases, de cese de huelgas y de los temas relacionados con los salarios, que en general eran su motivación fundamental.

Temas tan importantes como la profesión docente, sus logros, exigencias y retos, la calidad de la enseñanza, el maestro del día a día, el sujeto protagonista, actor social, agente de cambio y transformación, no aparecen en la agenda noticiosa del diario. Tampoco tiene cabida el maestro optimista, alegre, comprometido, que investiga, que cuestiona su quehacer, que escribe, satisfecho con su trabajo. Olvida el diario que los maestros no son solo quejas y malestar; también hay dentro del gremio la otra parte, que si el diario El Tiempo la reflejara, seguramente la visión negativa e inconforme sobre los maestros comenzaría a cambiar. La profesión docente como tal sería más valorada y más jóvenes querrían acceder a las facultades de educación, convencidos y orgullosos de su elección, y menos padres de familia agacharían la cabeza al señalar que sus hijos son profesores. 


\section{Apéndice lingüístico}

\section{Titulares del diario El Tiempo 1977-2005}

\section{Acciones de los maestros}

\section{Huelgas (HS)}

HS1 Pararían maestros de Nariño (27-02-77)

HS2 Amenazan con dos paros (28-02-77)

HS3 $\quad 7$ mil maestros en paro (02-03-77)

HS4 En alerta maestros en Tunja (15-03-77)

HS5 En alerta maestros en Tunja (15-03-77)

HS6 Paro de maestros en Guajira y Cesar (9-03-77)

HS7 Paro de maestros (07-04-77)

HS8 En Atlántico. Ultimátum a maestros en paro (22-04-77)

HS9 Fin a paro de maestros en el Chocó (22-04-77)

HS10 Paro por falta de profesores (05-05-77)

HS11 Paro de maestros en Atlántico (08-07-77)

HS12 Paro de maestros en Medellín (26-07-77)

HS13 Paro de maestros en Caldas (28-07-77)

HS14 Se extiende paro de educadores (30-07-77)

HS15 Parcial, paro de maestros en Antioquia (02-08-77)

HS16 Disturbios en Medellín: detienen 10 profesores (06-08-77)

HS17 Disturbios en Barranquilla (09-08-77)

HS18 El 23 paran Maestros (13-08-77)

HS19 Parcial paro de educadores en el país (23-08-77)

HS20 Fracasa el paro de los educadores en el país (24-08-77)

HS21 Educadores piden diálogo pero insisten en el paro (25-08-77)

HS22 Paro de 72 horas de los maestros de Cundinamarca (12-09-77)

HS23 Fin a paro de maestros en Caldas (16-09-77)

HS24 No se estudiarán sanciones mientras siga paro en FECODE (20-09-77)

HS25 Fue levantado paro de maestros (07-10-77) 
HS26 Maestros levantan paros (09-10-77)

HS27 Clases en el D.E. el 6 de febrero (21-01-78)

HS28 En paro 900 maestros de secundaria (22-02-78)

HS29 Paro en educación secundaria (09-03-78)

HS30 Paro parcial de maestros (16-03-78)

HS31 Educadores amenazan con paro en Antioquia (09-05-78)

HS32 Educadores anuncian paro (03-06-78)

HS33 Hoy paran maestros 24 horas (06-06-78)

HS34 Parcial el paro de maestros (09-06-78)

HS35 Paro nacional de magisterio (25-07-78)

HS36 Anuncian pago al Magisterio y ... decreta paro nacional (28-07-78)

HS37 Paro de magisterio (02-08-78)

HS38 Con manifestaciones públicas terminó el paro de magisterio (04-08-78)

HS39 Ilegal paro de maestros (30-09-78)

HS40 Cundinamarca sin clase por demora de salarios (07-02-79)

HS41 Se normaliza la situación en colegios (21-02-79)

HS42 'Jornada combativa' anuncian maestros (25-02-79)

HS43 Paro de maestros en Quindío (02-03-79)

HS44 Maestros levantan paro (s. f.)

HS45 Maestros paran por demora en pagos; lista la plata, dice el ministro Lloreda (10-05-79)

HS46 Pacífico el paro de maestros ayer (11-05-79)

HS47 En Antioquia. Paran 20 mil maestros (12-06-79)

HS48 Hoy no hay clases (01-08-79)

HS49 Maestros toman catedral de Armenia (18-9-79)

HS50 Mitin contra la secretaria de educación (16-11-79)

HS51 Arreglos en FF.NN. y Flota Mercante; paro de maestros

(21-03-80)

HS52 Maestros ratifican paro (25-03-80)

HS53 Paro de maestros hoy en el país (26-03-80)

HS54 En Bogotá. Total paro de maestros (27-03-80) 
HS55 Fue parcial, dice gobierno; un éxito, afirman educadores (27-03-80)

HS56 Descontarán un día de sueldo a maestros por participar en el paro (28-03-80)

HS57 30 mil maestros amenazan con paro (10-04-80)

HS58 Paro de maestros en Antioquia, mañana (11-05-80)

HS59 Hoy, protesta del magisterio (12-08-80)

HS60 Luego de casi un mes magisterio de Caldas levanta paro

(01-09-80)

HS61 Paro de maestros y de transporte en Valledupar (02-09-80)

HS62 Educadores ocupan FER (17-09-80)

HS63 Maestros de Antioquia apoyan paro (21-09-80)

HS64 Suspendido paro de los maestros (23-09-80)

HS65 Amenaza de paro lanzan maestros (10-10-80)

HS66 180 mil educadores irán a paro el 20 y 21 de octubre (11-10-80)

HS67 Ilegal y parcial, el cese de maestros (21-10-80)

HS68 Dice la Secretaria de Educación. Injusto el paro de maestros (22-10-80)

HS69 Paro de maestros en Valle (04-11-80)

HS70 Paro de maestros rechaza apertura del año escolar (03-02-81)

HS71 'Ya les pagamos... por favor inicien clase' (04-02-81)

HS72 Panorama laboral. Suben salarios de comunicaciones y maestros: FeCODE anuncia paro (13-02-81)

HS73 Maestros paran hoy (s. f.)

HS74 Parcial paro de maestros (26-02-81)

HS75 Gobierno no tolerará paro de maestros (05-03-81)

HS76 Con amenaza de paro maestros reciben nuevo Mineducación (17-03-81)

HS77 Suspenden paro de educadores (06-04-81)

HS78 Paro del magisterio de Cundinamarca (13-05-81)

HS79 Desórdenes por el paro (14-05-81)

HS80 Panorama laboral. Despidos por paro de CSTC; mítines en puertos; maestros cesarán el 9 (28-05-81) 
HS81 Hoy, paro de educadores en Cundinamarca (08-06-81)

HS82 Pacífico, paro de maestros (10-06-81)

HS83 Maestros anuncian paro (13-07-81)

HS84 Paro de maestros (17-07-81)

HS85 Paran 50 mil maestros en 6 departamentos (22-07-81)

HS86 En tres días pagarán a los maestros (23-07-81)

HS87 Rectores de secundaria apoyan paro de maestros (26-07-81)

HS88 Nuevo Ilamado a maestros (27-07-81)

HS89 Hoy deben reiniciarse las clases (29-07-81)

HS90 Hoy, clases en Bogotá. Se agrava paro en Cundinamarca (30-07-81)

HS91 Maestros regresan a clases (03-08-81)

HS92 Educadores anuncian paro en Risaralda (10-08-81)

HS93 Resumen nacional. Paro de educadores (11-08-81)

HS94 Levantan paros en colegios de Cundinamarca (12-08-81)

HS95 Hoy, paro nacional de maestros (17-04-85)

HS96 Quinto paro de maestros este año (18-08-81)

HS97 En Antioquia. Más de 200 profesores se reintegran a sus labores (22-08-81)

HS98 Hoy, paro nacional del FF.NN, mañana protesta de maestros (10-09-81)

HS99 Panorama laboral. Arreglo en Colmotores; hoy, protesta de maestros (11-09-81)

HS100 Comienza pago a maestros; ayer no hubo clases (03-10-81)

HS101 Suspendidos 30 maestros por no asistir a clases (27-10-81)

HS102 Mañana, paro nacional de maestros (17-11-81)

HS103 Maestros inician año escolar con... paro! (01-02-82)

HS104 Maestros de Antioquia piden mantener paro (12-08-81)

HS105 Maestros confirman paro (18-11-81)

HS106 Parcial paro de maestros (19-11-81)

HS107 Cesa paro en registraduría, siguen maestros (02-01-82)

HS108 Los maestros dejaron tareas y a protestar (02-02-82) 
HS109 Giran 5200 millones a los maestros, pero sigue el paro (03-02-82)

HS110 Revelan tabla de alza salarial para maestros y persiste el paro (03-02-82)

HS111 Persiste paro de maestros (05-02-82)

HS112 Arreglo en la flota; en marzo pararían maestros (25-02-82)

HS113 Panorama laboral. Mañana paro de maestros y manifestación en Bogotá (30-03-82)

HS114 Resumen judicial. Profesores se 'tomaron' las alcaldías de Tumaco e Ipiales (09-05-82)

HS115 Paro de maestros en Boyacá (23-07-82)

HS116 Pararon ayer 10.000 maestros en Medellín (27-07-82)

HS117 Paro indefinido de maestros en Boyacá (04-08-82)

HS118 Paran los 5000 maestros de Sucre (06-08-82)

HS119 Entran en paro 10 mil maestros (26-08-82)

HS120 Paro el 14. Paro de un día aprueban los maestros (04-09-82)

HS121 En paro el magisterio de Cesar (07-09-82)

HS122 Maestros levantan paro en Santander (08-09-82)

HS123 Levantado paro de maestros (25-09-82)

HS124 Paro en AdENAVI, alerta en maestros (21-01-83)

HS125 Paro indefinido de profesores (06-02-83)

HS126 En paro los maestros de San Andrés (11-02-83)

HS127 Educadores de San Andrés irían a paro (26-02-83)

HS128 Paro en el magisterio el jueves (01-03-83)

HS129 FECODE y ADE confirman paro nacional de 180.000 maestros (02-03-83)

HS130 El Mineducación y estudiantes piden a maestros no hacer paro (03-03-83)

HS131 Sin clases 7 millones de estudiantes (04-03-83)

HS132 Marcha de maestros hoy en el país (21-04-83)

HS133 Paro de maestros de 48 horas, anuncia FeCODE (03-05-83)

HS134 Paro de dos días inician hoy 200 mil maestros (04-05-83)

HS135 Sigue paro de maestros en cuatro departamentos (06-05-83) 
HS136 Nuevos paros anuncian maestros; gobierno investiga caos en pagos (07-05-83)

HS137 Maestros se tomarán la gobernación; estalla una bomba en la U. de Antioquia (21-05-83)

HS138 Paro de educadores en el Cesar (24-05-83)

HS139 Paro de educadores en San Andrés; protestas por cortes de energía (10-08-83)

HS140 Paro de 7 mil educadores en Atlántico; despedidos más de 100 en Córdoba (12-08-83)

HS141 180.000 maestros harán paro de un día el jueves (16-08-83)

HS142 Hoy, jornada de protesta de maestros (18-08-83)

HS143 Pacífica jornada de educadores (19-08-83)

HS144 Manifestación por falta de maestros (27-08-83)

HS145 Paro indefinido de maestros (05-09-83)

HS146 Vistazo a Colombia. Sigue paro a de maestros en Santander (27-09-83)

HS147 Miles de educadores a Bogotá (30-09-83)

HS148 Educadores, satisfechos por jornada de protesta (02-10-83)

HS149 Maestros del Valle insisten en el paro (16-10-83)

HS150 Termina paro de maestros en el Valle (15-11-83)

HS151 Vistazo a Colombia. Profesores levantan paro (18-11-83)

HS152 Vistazo a Colombia. 200 mil estudiantes a punto de perder el año (30-11-83)

HS153 Protestan maestros del Chocó (11-01-84)

HS154 Continúa toma de FER por maestros (12-01-84)

HS155 Por falta de pagos maestros se niegan a trabajar el lunes 6 (03-02-84)

HS156 Mañana paro nacional de maestros estatales (22-02-84)

HS157 Paro de educadores (22-02-84)

HS158 El 29, huelga en Paz del río, anuncian paros de aviación y maestros (27-02-84)

HS159 Anuncian paro nacional en magisterio y aviación (01-03-84)

HS160 Maestros del D. E. se toman secretaría (02-03-84) 
HS161 Anuncian paros en salud y magisterio (07-03-84)

HS162 Paro de educadores en Quindío (07-03-84)

HS163 Mitin de profesores en Santander (16-03-84)

HS164 Paro de maestros en Chocó (03-04-84)

HS165 Maestros amenazan con paro nacional (12-04-84)

HS166 Paro nacional de maestros el 8 (05-05-84)

HS167 Piden a maestros no ir a la huelga (08-05-84)

HS168 Parcial, paro de maestros (09-05-84)

HS169 Descuentan 2 días de sueldo a 140 mil maestros por paro (10-05-84)

HS170 Paro de educación sube a 40\% (10-05-84)

HS171 Maestros preparan marcha (11-05-84)

HS172 Educación. Sigue el paro, gobierno y D. E. aclararán responsabilidades (12-05-84)

HS173 Parálisis total en educación, FECODE busca arreglo (12-05-84)

HS174 En paro celebran 'día del maestro' (15-05-84)

HS175 Ocho días sin clase por paro de maestros (15-05-84)

HS176 El 90 por 100 del magisterio está en paro (17-05-84)

HS177 FECODE continúa el paro (17-05-84)

HS178 Maestros radicalizan protestas; gobierno pide cordura y clases (18-05-84)

HS179 El jueves levantarían paro de maestros (20-05-84)

HS180 Concentración de maestros en Caquetá (23-05-84)

HS181 Maestros del Chocó marchan a Bogotá (23-05-84)

HS182 Clases extras en junio por paro de maestros (24-05-84)

HS183 Gobierno anticipó las vacaciones a maestros (25-05-84)

HS184 12 días se descontarán a maestros (30-05-84)

HS185 Maestros ocuparon ayer dos embajadas (01-06-84)

HS186 Detenidos 45 profesores (01-06-84)

HS187 Maestros ofrecen compensar clases en diciembre (02-06-84)

HS188 En paro magisterio de N. de Santander (04-07-84)

HS189 Levanta paro el magisterio de Bolívar (01-09-84)

HS190 Maestros definirán paro el 27 (22-09-84) 
HS191 Maestros y empleados públicos realizan hoy paro de 24 horas (14-11-84)

HS192 Maestros declaran huelga de hambre en el Concejo (07-12-84)

HS193 Retirados por desmayo dos de los maestros en huelga de hambre (10-12-84)

HS194 Educadores tomaron rehén al gobernador de Boyacá (12-12-84)

HS195 En huelga de hambre, maestros que se tomaron gobernación de Boyacá (14-12-84)

HS196 Maestros levantan huelga de hambre (15-12-84)

HS197 Paran los maestros del Quindío (03-02-85)

HS198 Con paro comenzó ayer el año escolar (05-02-85)

HS199 Con paro se inició pago a maestros (05-03-85)

HS200 Grupo de maestros en huelga de hambre (11-04-85)

HS201 Paro de maestros de 48 horas y agitación laboral en 4 empresas (15-04-85)

HS202 Sancionan a maestros; 'tomas' de 5 ciudades hoy (18-04-85)

HS203 Maestros reanudan clase hoy, pero anuncian otro paro

(19-04-85)

HS204 La huelga de maestros (21-04-85)

HS205 Anuncian paro en salud y magisterio (24-04-85)

HS206 Dice Mintrabajo: 'Ilegales' paros en FN, en suspenso paro de maestros (25-04-85)

HS207 Protestas por conflictos en Sena, magisterio y transporte (08-05-85)

HS208 Paro de educadores en Bolívar (14-05-85)

HS209 Paro de maestros en Boyacá (23-05-85)

HS210 17 arreglos laborales, anuncian paros en el Magisterio y Salud (15-07-85)

HS211 Protestan maestros por falta de pago (15-08-85)

HS212 Asesinados dos maestros ayer; paro cívico en Puerto López (27-08-85)

HS213 En Cundinamarca. Profesores realizarán paro de 48 horas (11-09-85) 
HS214 Maestros pagan \$700 mil en manifestación (12-09-85)

HS215 Paro de 48 horas del magisterio (25-09-85)

HS216 Principio de acuerdo para levantar paro de maestros (26-09-85)

HS217 Hoy, paro nacional de maestros (20-02-86)

HS218 Levantan paro parcial de maestros pero anuncian otro antes de elecciones (21-02-86)

HS219 Paro de maestros en Bogotá (20-03-86)

HS220 Logran acuerdo con los maestros (21-03-86)

HS221 Paro de 72 horas en mayo anuncian maestros (05-04-86)

HS222 Paro de 3 días en el magisterio (06-05-86)

HS223 Ampliación del paro estudian hoy maestros (09-05-86)

HS224 En suspenso el paro de maestros (10-05-86)

HS225 Suspensión parcial del paro de maestros (11-05-86)

HS226 Maestros se reintegran hoy; buscan solución en tres departamentos (13-05-86)

HS227 Paros de maestros aumentan ocio de los estudiantes (13-05-86)

HS228 Solo el lunes se reintegrarán 57 mil maestros que siguen en paro (15-05-86)

HS229 Continúa huelga de maestros en tres departamentos (17-05-86)

HS230 Paran maestros en el Quindío (06-09-86)

HS231 En Girardot. Manifestación contra amenazas a docentes (22-10-86)

HS232 Con bloqueo de tránsito piden nombramiento de profesores (31-01-87)

HS233 Paro de maestros desde hoy en Cundinamarca (02-02-87)

HS234 Maestros preparan paro nacional por conflictos en varios departamentos (03-02-87)

HS235 Levantan paro los maestros de Cundinamarca (05-02-87)

HS236 Maestros de Cundinamarca hicieron paro (21-03-87)

HS237 En paro el magisterio de Caquetá (01-04-87)

HS238 Conjurado paro de maestros de Cundinamarca (02-04-87)

HS239 Emergencia educativa y paro de maestros en el Quindío (25-04-87) 
HS240 Paro de maestros en mayo (26-04-87)

HS241 Paran maestros departamentales de Bolívar (12-07-87)

HS242 Los maestros paran dos días (26-08-87)

HS243 Hoy continúa paro de maestros (27-08-87)

HS244 Nuevo paro en magisterio por muerte de 2 educadores (01-09-87)

HS245 Paro de maestros en Bogotá (09-09-87)

HS246 Concluye sin acuerdo paro de educadores distritales (10-09-87)

HS247 Paro de educadores en Cundinamarca (21-09-87)

HS248 Paran 15 mil maestros de Cundinamarca (06-10-87)

HS249 Arreglo laboral con los maestros de Cundinamarca (07-10-87)

HS250 Ante propuesta del gobierno, maestros convocan a un paro nacional (23-10-87)

HS251 Maestros descontentos, convocan a paro nacional (23-10-87)

HS252 Paro de maestros se inicia hoy (28-10-87)

HS253 Grave situación laboral, el martes pararán maestros y estatales (16-01-88)

HS254 Paro nacional de maestros en abril (23-01-88)

HS255 Paran los maestros de Bogotá (03-02-88)

HS256 Por incumplimiento en pago de salarios, 200.000 maestros paralizan la educación pública (27-04-88)

HS257 A pesar de la enérgica condena del gobierno, el paro de maestros continúa hoy en el país con marchas y asambleas (29-04-88)

HS258 Por muerte y desaparición de maestros, paros del magisterio en Magdalena y Santander (01-06-88)

HS259 Gobernadora de Caldas rechaza paro de maestros (10-06-88)

HS260 Amenaza de paro por asesinatos (18-08-88)

HS261 Persiste huelga de hambre de 60 educadores (25-08-88)

HS262 Arreglo directo en Nariño. Concluyó la huelga de hambre del magisterio (29-08-88)

HS263 Habrá paro indefinido de maestros (14-12-88)

HS264 ¿Se reanudarán las clases bajo amenaza de un paro?, ¡maestros, al tablero! (05-02-89) 
HS265 Otra protesta de los docentes (16-02-89)

HS266 Córdoba. Paro de maestros (18-03-89)

HS267 19 de abril: paran 200.000 maestros (30-03-89)

HS268 Chocó. Paro educativo (11-04-89)

HS269 Oscuro panorama laboral en 3 departamentos. A paro de maestros en Antioquia y Caquetá (11-04-89)

HS270 Mineducación dispuesto al diálogo, el gobierno no aceptará el paro de los educadores (12-04-89)

HS271 Mientras buscan acuerdos a nivel nacional, se generaliza el paro (14-04-89)

HS272 A 36 horas del paro aun no hay arreglo con los maestros (18-04-89)

HS273 El Ministerio de educación no justifica la actitud de FECODE. La amenaza de paro continúa por el eterno descontento de los maestros (18-04-89)

HS274 El paro perpetuo (19-04-89)

HS275 Hoy habrá clases normalmente, maestros suspenden paro (19-04-89)

HS276 A pesar de la cancelación del paro, no todo fue normal ayer en las escuelas (20-04-89)

HS277 Maestros de Córdoba se tomaron un edificio (18-05-89)

HS278 Los profes quieren parar (08-07-89)

HS279 Profes en paro (26-07-89)

HS280 Paran maestros: 20 mil afectados (10-08-89)

HS281 Por la «toma de Bogotá» despedirán maestros que no dicten clases (16-08-89)

HS282 El gobierno rechaza marcha de maestros (17-08-89)

HS283 Más de 50 mil personas marcharon en Bogotá. Magisterio votará hoy paro desde septiembre (18-08-89)

HS284 Los maestros anuncian cese de actividades (25-08-89)

HS285 Maestros cambian paro por 2 ceses de actividades (05-09-89)

HS286 Afectados 6 millones de estudiantes, 200.000 docentes estatales en paro (07-09-89) 
HS287 No pagarán a los maestros que no laboren (08-09-89)

HS288 Hoy, nuevo paro. No pagarán a maestros que no trabajen (13-09-89)

HS289 A pesar de las advertencias de no pago, maestros pararon; hoy sigue la huelga (s. f.)

HS290 A partir de mañana. Paro indefinido de los maestros (19-09-89)

HS291 Acuerdo de última hora. Definitivo: no hay paro de maestros (20-09-89)

HS292 Pese al acuerdo firmado, paro parcial de maestros (21-09-89)

HS293 Paro de maestros en tres departamentos (05/09/90)

HS294 Finaliza paro de maestros en el Tolima (16/09/90)

HS295 Paro de 24 horas en el magisterio (19/09/90)

HS296 Maestros a media marcha (28/09/90)

HS297 Maestros colombianos se unen a paro continental (17/10/90)

HS298 Ayer, paro parcial de maestros (18/10/90)

HS299 El distrito perdió ochenta millones de pesos. Maestros elegibles se tomaron ayer tesorería (18/10/90)

HS300 Educadores paran en 5 regiones (30/10/90)

HS301 Hoy culmina paro de 48 horas en Cauca, vuelven las clases en Córdoba y siguen en veremos en Sucre (07/11/90)

HS302 Fin de paro de maestros (23/11/90)

HS303 Maestros de Sucre y córdoba recuperan el tiempo perdido: clases los sábados y domingos (29/11/90)

HS304 Los maestros están en paro (19/01/91)

HS305 Habrá paro en magisterio del Valle (21/01/91)

HS306 Empiezan paros de maestros (22/01/91)

HS307 Los maestros mantienen orden de paro (02/02/91)

HS308 No hay razón para el paro, dice el gobierno (04/02/91)

HS309 Paro de maestros, injusto con Bogotá (05/02/91)

HS310 Hubo paro de maestros (05/02/91)

HS311 Los padres de familia también empezaron a protestar por el paro (06/02/91) 
HS312 Maestros deciden hoy la suerte del paro (06/02/91)

HS313 Los padres de familia también empezaron a protestar por el paro (06/02/91)

HS314 Mañana levantan paro de maestros (07/02/91)

HS315 Seguirán en paro (10/02/91)

HS316 Sigue en paro el magisterio (13/02/91)

HS317 Maestros siguen en paro (14/02/91)

HS318 Maestros vuelven a hacer paro hoy (14/02/91)

HS319 Alumnos sin clase (18/02/91)

HS320 Maestros cumplen 3 semanas en paro (20/02/91)

HS321 Fin a paro de maestros (21/02/91)

HS322 Casi 30 mil alumnos aún esperan a sus profesores (27/02/91)

HS323 Maestros, de nuevo en paro en Antioquia y Boyacá (06/03/91)

HS324 Paro o no más paro (12/03/91)

HS325 No paran el paro (13/03/91)

HS326 Fin de paro (31/03/91)

HS327 Maestros del país, entre amenazas de muerte y paros (03/04/91)

HS328 Marcha por despido de 165 profesores (03/04/91)

HS329 Córdoba: paro de maestros (25/04/91)

HS330 Paran dos mil maestros (29/05/91)

HS331 Cinco millones de estudiantes se quedaron sin clases ayer (31-5-91)

HS332 Paran dos mil maestros (29/05/91)

HS333 Se extiende el paro (06/06/91)

HS334 Paro en Urabá por muerte de una profesora (13/06/91)

HS335 Paro de maestros (16/07/91)

HS336 Paro nacional de educadores el 13 de agosto (25/07/91)

HS337 Maestros protestan por crímenes (31/07/91)

HS338 En Antioquia: paran maestros (05/08/91)

HS339 Paro de maestros (06/08/91)

HS340 Paro del 80 en el magisterio oficial (14/08/91)

HS341 Terminó paro de maestros (15/08/91)

HS342 Maestros del Valle insisten en el paro (04/09/91) 
HS343 Nuevo paro de maestros en Antioquia (16/09/91)

HS344 Magisterio continúa paro (17/09/91)

HS345 Magisterio anuncia cese indefinido de actividades (11/10/91)

HS346 500 profesores, en paro (18/02/92)

HS347 Profesores siguen en paro (14/03/92)

HS348 Maestros vuelven a clase (26/04/92)

HS349 800 profesores en paro (07/05/92)

HS350 No hay clases: magisterio (12/05/92)

HS351 Insisten en paro indefinido (16/05/92)

HS352 Paro de maestros (04/06/92)

HS353 Paro de maestros (13/07/92)

HS354 Paro de maestros (28/07/92)

HS355 Profesores cesan labores (07/08/92)

HS356 Mil maestros siguen en paro (13/08/92)

HS357 Los maestros se toman el concejo (14/08/92)

HS358 Antioquia: paro de maestros (07/09/92)

HS359 Antioquia: sigue paro de maestros (08/09/92)

HS360 Maestros paisas levantan el paro (24/09/92)

HS361 Maestros de la costa también pararon ayer (16/10/92)

HS362 Sigue protesta de los maestros temporales (24/10/92)

HS363 Paro de maestros $(07 / 11 / 92)$

HS364 Protestas contra ley de educación (16/12/92)

HS365 Maestros se toman alcaldía (23/01/93)

HS366 Paro de maestros en Socotá (27/01/93)

HS367 Profesores del INEM a paro (30/01/93)

HS368 Magisterio en paro (04/02/93)

HS369 Protesta de maestros (03/03/93)

HS370 Paro de maestros (13/03/93)

HS371 Levantan paro (27/03/93)

HS372 Paro deja sin clases a 20.000 niños en Cúcuta (17/04/93)

HS373 Maestros anuncian paro (22/04/93)

HS374 Habría paro nacional de maestros (12/05/93)

HS375 Fantasma de paro en día del educador (14/05/93) 
HS376 Hoy, paro de educadores (18/05/93)

HS377 Parcial el paro de maestros: gobierno (19/05/93)

HS378 El paro de maestros (19/05/93)

HS379 Tutela de padre de familia contra el paro de maestros (22/05/93)

HS380 Hoy, marcha de maestros en Bogotá (26/05/93)

HS381 Paro docente será declarado ilegal (27/05/93)

HS382 Tutela por paro (28/05/93)

HS383 Se complica arreglo con los docentes (28/05/93)

HS384 Se vislumbra fin del paro de maestros (30/05/93)

HS385 Se mantiene el paro de los maestros (31/05/93)

HS386 Se reanuda diálogo con los maestros (01/06/93)

HS387 Los colegios privados contra paro de FECODE (02/06/93)

HS388 Gobierno declara ilegal paro docente (03/06/93)

HS389 Solidaridad con maestros (05/06/93)

HS390 Un paro ilegal (05/06/93)

HS391 Cercano, un acuerdo con los maestros (05/06/93)

HS392 Maestros vuelven hoy a las clases (08/06/93)

HS393 Acuerdo definitivo con el magisterio (10/06/93)

HS394 Paro de cinco mil maestros (03/08/93)

HS395 Pare al paro (10/08/93)

HS396 Paran maestros (25/08/93)

HS397 Paran maestros (27/08/93)

HS398 Caquetá: 15.000 niños afectados por cese docente (08/09/93)

HS399 Paran profesores (04/11/93)

HS400 Para el magisterio (06/11/93)

HS401 Los maestros protestan por presupuesto (26/11/93)

HS402 Maestros levantan paro (06/12/93)

HS403 Paro de maestros (03/02/94)

HS404 Por amenazas, maestros no irían a clase (12/02/94)

HS405 Paros en Caquetá y Caldas (15/02/94)

HS406 Maestros de Caldas en paro (16/02/94)

HS407 Sanciones y paro (23/02/94)

HS408 Paro de maestros (02/03/94) 
HS409 Paro de maestros en Cundinamarca (04/03/94)

HS410 Termina paro de maestros (05/03/94)

HS411 Puede haber nuevo paro de maestros (04/04/94)

HS412 Paro de maestros (07/04/94)

HS413 Paro de maestros en Arauca (12/04/94)

HS414 Paro de maestros y estudiantes (13/04/94)

HS415 Maestros en paro (13/04/94)

HS416 Maestros bloquean vía (21/04/94)

HS417 Paro educativo (26/04/94)

HS418 Paro (30/04/94)

HS419 Hoy marchan los maestros distritales (11/05/94)

HS420 Hoy, marcha de maestros (11/05/94)

HS421 Acuerdo con los maestros (12/05/94)

HS422 Paro de maestros (02/06/94)

HS423 Paran profesores (20/07/94)

HS424 Levantan paro maestros (10/08/94)

HS425 Paro de maestros (11/08/94)

HS426 Rechazo a paro de maestros (18/08/94)

HS427 Maestros se toman iglesia (31/08/94)

HS428 Habrá paro de maestros (08/10/94)

HS429 Caquetá se une a paro de maestros (11/10/94)

HS430 Alumnos de puente, por paro de maestros (14/10/94)

HS431 En Bogotá paró el 70 por ciento de las escuelas (14/10/94)

HS432 Los maestros van a paro (12/01/95)

HS433 Paro anticipado de maestros (02/02/95)

HS434 Maestros al borde del paro (05/02/95)

HS435 Arranca paro de maestros (06/02/95)

HS436 Gobierno negociará si FeCODE levanta paro (07/02/95)

HS437 Se rebelaron seis mil maestros (13/02/95)

HS438 Maestros siguen en huelga en cuatro departamentos (14/02/95)

HS439 Aunque se levantó el paro, en dos centros no hubo clase (14/02/95)

HS440 Acabó paro de maestros (15/02/95) 
HS441 Paro educativo (03/03/95)

HS442 Paro en bachillerato (08/03/95)

HS443 Levantan paro (08/03/95)

HS444 Reinician clases (10/03/95)

HS445 Los maestros amenazan con nuevo paro (17/04/95)

HS446 Maestros en paro (18/04/95)

HS447 Maestros en paro serían despedidos (25/04/95)

HS448 Gobierno y maestros siguen sin acuerdo (28/04/95)

HS449 Paro de maestros (29/04/95)

HS450 Inminente paro de maestros oficial (03/05/95)

HS451 Maestros inician paro indefinido el lunes (04/05/95)

HS452 En Bogotá, maestros listos para parar (05/05/95)

HS453 Gremios rechazan paro de maestros (05/05/95)

HS454 Hoy inicia paro nacional de maestros (08/05/95)

HS455 Sancionarán a maestros en paro (09/05/95)

HS456 Sanción a maestros que paren (09/05/95)

HS457 Maestros del distrito anuncian que no van a detener el paro (10/05/95)

HS458 Paro docente sería ilegal (10/05/95)

HS459 Distrito quiere ir al diálogo sobre paro (12/05/95)

HS460 Declaran ilegal paro de maestros (13/05/95)

HS461 Protesta de maestros (16/05/95)

HS462 Maestros preparan marcha para mañana (24/05/95)

HS463 Maestros de Nariño continúan en paro (26/05/95)

HS464 Fin de un paro (28/05/95)

HS465 Uno, dos y tres, maestros otra vez (30/05/95)

HS466 Médicos y maestros, en paro (04/06/95)

HS467 Maestros siguen en paro (06/06/95)

HS468 Piden declarar ilegalidad de paro de maestros (15/06/95)

HS469 Maestros siguen en paro (16/06/95)

HS470 Los maestros ratifican el paro (01/07/95)

HS471 En 10 días debe finalizar paro de maestros: Mineducación $(28 / 07 / 95)$ 
HS472 Acercamientos entre maestros y ministra (02/08/95)

HS473 Paro de maestros en Caldas (10/08/95)

HS474 Protesta de 550 maestros que no quieren irse de Bogotá $(11 / 10 / 95)$

HS475 Amenaza de paro (16/02/96)

HS476 Paran maestros en Risaralda (21/02/96)

HS477 Paro del magisterio (01/03/96)

HS478 Paro de 48 horas (05/03/96)

HS479 Paro de maestros (14/03/96)

HS480 Paran los maestros (19/04/96)

HS481 Maestros a paro (23/04/96)

HS482 Paro de maestros (24/04/96)

HS483 Paran los maestros (17/05/96)

HS484 Paran 24 horas los colegios del estado (06/08/96)

HS485 Maestros se van a paro (06/08/96)

HS486 Paran los docentes (17/08/96)

HS487 Maestros se tomaron gobernación de N. de Santander $(27 / 08 / 96)$

HS488 Maestros de Antioquia mantienen el paro (10/09/96)

HS489 Maestros antioqueños insisten en el paro (14/09/96)

HS490 Maestros siguen en paro (19/09/96)

HS491 Maestros siguen en paro (20/09/96)

HS492 Prohibido parar. Foto leyenda (25/09/96)

HS493 Hoy, paro de maestros (25/09/96)

HS494 Continúa amenaza de paro indefinido de maestros (26/09/96)

HS495 El paro, la locura para las mamás (26/09/96)

HS496 Maestros del Huila entraron en paro (02/10/96)

HS497 Aún sigue latente paro de maestros (08/10/96)

HS498 A un punto de cancelarse paro de maestros (09/10/96)

HS499 Los profesores de Antioquia vuelven a clases (07-10-96)

HS500 Protesta por pelea de profesores (09/10/96)

HS501 No hay paro de maestros (10/10/96)

HS502 Profesores se tomaron defensoría del pueblo en Pasto (06/11/96) 
HS503 Inminente paro de maestros oficiales (11/01/97)

HS504 Profesores se unirán a paro nacional (30/01/97)

HS505 Por amenazas, 85 maestros no iniciaron clases en Bolívar (04/02/97)

HS506 Exigencias, regateos y promesas en 2 años y medio (10/02/97)

HS507 Un maestro en contravía: no al paro (11/02/97)

HS508 En medio del paro, vuelven hoy las negociaciones (13/02/97)

HS509 25.000 maestros distritales en paro (13/02/97)

HS510 Nuevo paro educativo en Norte de Santander (28/02/97)

HS511 Paro de educadores (09/05/97)

HS512 Paro por asesinato de profesor (13/05/97)

HS513 Profesores reclaman derechos (19/05/97)

HS514 Paro cívico en Arauca por muerte de profesores (06/06/97)

HS515 Sigue huelga de hambre de ocho profesores en Sogamoso, Boyacá (06/06/97)

HS516 Sigue huelga de hambre de ocho profesores en Sogamoso, Boyacá (05/07/97)

HS517 Por amenazas, paran maestros (23/07/97)

HS518 Maestros distritales marchan hoy (25/07/97)

HS519 Foro para preparar un paro distrital de educadores en agosto (29/07/97)

HS520 Maestros distritales definen si se van a paro (19/08/97)

HS521 Aprobado paro de maestros del distrito (23/08/97)

HS522 Paro dejará sin clases a 700 mil estudiantes (25/08/97)

HS523 Hoy no habrá clases en el distrito (27/08/97)

HS524 Lo peor del paro es que los niños se atrasen en clases, opinan padres $(27 / 08 / 97)$

HS525 Paro en 80 de los colegios (28/08/97)

HS526 Maestros marcharon mientras comisiones reanudaron diálogos $(29 / 08 / 97)$

HS527 Educadores confirman paro del 26 de febrero (21/02/98)

HS528 En huelga de hambre 90 educadores (08/05/98)

HS529 Paro indefinido de maestros en el Huila (17/09/98)

HS530 Maestros se encadenan en la gobernación de Nariño (02/10/98) 
HS531 Los maestros del país protestan hoy (30/12/98)

HS532 Educadores protestan en templo de Baranoa (22/03/99)

HS533 Paro de maestros, montado sobre la desinformación (24/04/99)

HS534 Paro docente, montado sobre la desinformación (24/04/99)

HS535 Educación: regreso a la anormalidad (10/05/99)

HS536 Hambre, único camino de maestros de Tolú (01/07/99)

HS537 Maestros del Meta se toman gobernación (04/09/99)

HS538 Por falta de pago, maestros ocupan templo (08/09/99)

HS539 Marchas pacíficas de maestros en todo el país (21/10/99)

HS540 Profesores marcharon y protestaron en paz (21/10/99)

HS541 Paro de maestros (01/11/99)

HS542 Los profesores del distrito se rebelan (01/06/2000)

HS543 A maestros que paren no se les pagará (07/06/2000)

HS544 En clase, a regañadientes (20/06/2000)

HS545 Sin clases en 2 departamentos (23/08/2000)

HS546 Cuarta semana de paro (25/08/2000)

HS547 7 mil niños sin clases (25-08-2000)

HS548 Amenaza de paro (04/09/2000)

HS549 Terminó paro de profesores (25/09/2000)

HS550 Niños marchan a la brava (16-06-2001)

HS551 Maestros se mantienen en paro (07/02/2002)

HS552 Marchas en favor de profesores (16/02/2002)

HS553 Educadores, en desobediencia civil (01/03/2002)

HS554 Maestros protestan por decreto. Foto (15/03/2002)

HS555 Sin clases por amenazas (13/05/2002)

HS556 Hoy, paro de buses y maestros (27/11/2002)

HS557 Continúa paro en la Montessori (04/03/2003)

HS558 Paro del magisterio (13/05/2003)

HS559 Sin clases por falta de maestros (19-02-2004)

HS560 Hoy, paro de profesores (22/07/2004)

\section{Aspectos Judiciales (AJ)}

AJ1 Desaparece profesor (12-01-77)

AJ2 ¿Y esto por qué? Maniático sexual nombrado maestro oficial de niños $(01-02-77)$ 
AJ3 Murió el grosor Casas M. (26-02-77)

AJ4 Perece ahogada profesora (08-03-77)

AJ5 Policía y profesora perecen en choque (04-06-77)

AJ6 9 años de cárcel a ex profesor (05-07-77)

AJ7 Falleció conocido educador (31-12-77)

AJ8 Un detenido por secuestro de profesor (04-02-78)

AJ9 Chofer ataca a bala bus escolar: 2 heridos (06-04-78)

AJ10 Asesinado ayer un profesor (29-05-78)

AJ11 Vendetta entre FARC por una maestra: 4 muertos (15-08-78)

AJ12 Maestra del Quindío arrestada con coca (27-08-78)

AJ13 2 maestras dirigen invasiones (15-09-78)

AJ14 Profesor ruso muere cuando dictaba clase (07-12-78)

AJ15 En la sabana de Bogotá. Alcaldes enjuician a los educadores (14-05-79)

AJ16 Segunda brigada niega torturas a institutora (04-06-79)

AJ17 Pereció educadora bogotana (16-06-79)

AJ18 Magisterio acusa a caja de previsión por drama de maestra (03-08-79)

AJ19 Detenido ex directivo de FECODE (21-09-79)

AJ20 Extraño secuestro de una educadora (04-01-80)

AJ21 Profesor de idiomas murió intoxicado (18-05-80)

AJ22 Asesinado un profesor (15-08-80)

AJ23 Perecieron dos educadores (30-09-80)

AJ24 Asesinado profesor (08-03-81)

AJ25 Profesor niega vínculos con el M-19 (09-05-81)

AJ26 Profesor lesiona a una alumna (11-05-81)

AJ27 Profesores denuncian hostilidad policial (25-05-81)

AJ28 Falleció educadora en Quibdó (29-05-81)

AJ29 M-19 asalta colegio en Cali y huye con profesor como rehén (20-06-81)

AJ30 Pereció profesor (15-09-81)

AJ31 ELN asesina un profesor cuando dictaba su clase (02-03-82)

AJ32 Resumen judicial. Las FARC secuestran a inspector; 10 detenidos por la muerte de maestro (07-03-82) 
AJ33 Terrorista herida llevaba doce años como educadora (30-03-82)

AJ34 Acribillado profesor en el Caquetá (02-04-82)

AJ35 Fallo favorable a maestros suspendidos en Bogotá el año 76 (03-06-82)

AJ36 Muerto profesor taxista; protesta de conductores (10-09-82)

AJ37 Resumen judicial. Profesor ebrio mató a un niño e hirió a 2 personas (26-11-82)

AJ38 Acusados un profesor y otras 7 personas por crimen de Gloria Lara (23-12-82)

AJ39 Extraña muerte de un profesor (04-01-83)

AJ40 Pereció profesora en accidente (13-06-83)

AJ41 Resumen Judicial. Asesinados profesor y estudiante en Popayán (27-07-83)

AJ42 Porque perdió una materia le fracturó el cráneo a profesora (26-11-83)

AJ43 Extraña muerte de educadora (24-01-84)

AJ44 Resumen Judicial. Profesores denuncian amenazas en Bolívar (10-02-84)

AJ45 Falleció el educador Hernando Núñez Navas (24-02-84)

AJ46 Cuídese, le había dicho el maestro de colegio a Lara B. (04-05-84)

AJ47 Detenidos 45 profesores (01-06-84)

AJ48 Errores oficiales. Reintegran a un maestro 'oprobio de la educación' (14-06-84)

AJ49 Violento fin de semana en Medellín; asesinado un educador en Florencia (07-08-84)

AJ50 Destituidos 32 profesores en Medellín (01-09-84)

AJ51 Amenazados 4 profesores (11-10-84)

AJ52 Desaparece profesor en el Cauca (28-11-84)

AJ53 Retenidos dos profesores en Bucaramanga (28-11-84)

AJ54 Muerto profesor en Valledupar (30-11-84)

AJ55 Asesinado educador y otro hombre en Pereira (05-12-84)

AJ56 Asesinado profesor en Montería (24-04-85) 
AJ57 Guerrilleros asesinaron a maestra en Cimitarra (01-06-85)

AJ58 ELN niega amenazas a profesores (13-06-85)

AJ59 Profesora de 'Camina' y profesor universitario capturados con armas (21-06-85)

AJ60 Procesos disciplinarios contra 300 educadores (15-09-85)

AJ61 En Armero murieron 99 maestros y 4000 estudiantes (25-11-85)

AJ62 Un profesor desaparecido (17-01-86)

AJ63 Muerta en Loma Linda maestra de ILV (06-05-86)

AJ64 Escándalo en Zipaquirá. Mineducación pide a procuraduría investigar a maestros inmorales (24-05-86)

AJ65 Anuncia Mineducación. Magisterio tendrá nuevo régimen disciplinario (23-06-86)

AJ66 Por los juzgados. Procesados abogado y ex maestra por estafa (23-07-86)

AJ67 En planteles distritales. Una bala para cada profesor (26-09-86)

AJ68 Un maestro entre víctimas de helicóptero (10-08-87)

AJ69 En el Valle. Porque lo rajó, un alumno mató a profesor (01-09-87)

AJ70 Muerte de profesor. Una broma macabra, la causa del crimen (02-09-87)

AJ71 Amenazan de muerte a 3 profesores (16-09-87)

AJ72 En el Valle. Crimen de profesor de filosofía (20-09-87)

AJ73 Crimen de Pardo Leal, libre el profesor que alquiló el carro (17-10-87)

AJ74 Asesinado educador en Barrancabermeja (27-02-88)

AJ75 Secretario de corregiduría mató a líder de magisterio (09-06-88)

AJ76 Ola de crímenes en el Meta. Muertos secretario liberal y un profesor de música (21-06-88)

AJ77 Educadores dicen tener pruebas de amenazas (26-06-88)

AJ78 Bomba en sede de educadores (28-07-88)

AJ79 Muerto educador y herida su esposa (04-08-88)

AJ80 Cargos a profesor por abuso sexual (12-08-88) 
AJ81 Asesinados dos maestros en Antioquia (10-11-88)

AJ82 Sicarios matan a un abogado y a maestro (24-11-88)

AJ83 Asesinados dos maestros (03-01-89)

AJ84 Amenazan a 20 maestros del Norte de Santander (11-01-89)

AJ85 Asesinado ayer otro educador en Medellín (13-01-89)

AJ86 Amenazan a alcaldesa y a 70 profesores (25-01-89)

Aj87 Economía de la violencia. Maestros venden sus plazas en forma ilegal (02-02-89)

AJ88 La intoxicación en la Merced. Profesores, ¿otras víctimas de venganzas? (20-02-89)

AJ89 Sin esclarecer caso de la Merced, requieren hiposulfito de sodio para profesores intoxicados (21-02-89)

AJ90 A pocos días de la intoxicación. Amenazados cuatro maestros de la Merced (03-03-89)

AJ91 Asesinado profesor en absurda riña (13-03-89)

AJ92 Bomba en casa de un profesor (15-03-89)

AJ93 Graves denuncias hacen los maestros de Bucaramanga (09-04-89)

AJ94 Muerta maestra de primaria (24-04-89)

AJ95 Juzgan a tres detectives por el crimen de dos profesores (26-05-89)

AJ96 Siguen los crímenes en Urabá. Asesinado profesor rural en Arboletes (27-05-89)

AJ97 Atentado contra un profesor (30-05-89)

AJ98 Asesinado educador en Bogotá (30-05-89)

AJ99 En los últimos meses se han registrado 15 casos. Magisterio de Santander denuncia desaparición y muerte de maestros (15-06-89)

AJ100 Según el Consejo de Estado. Maestros, sin derecho a permisos sindicales (12-7-99)

AJ101 Asesinados 2 profesores en Antioquia (31-07-89)

AJ102 Liberados cuatro profesores (14-10-89)

AJ103 Policía mata maestro (18-10-89)

AJ104 Asesinado un profesor (26-10-89) 
AJ105 Asesinan en Meta a maestra de up (24-11-89)

AJ106 Asesinado profesor (09-12-89)

AJ107 Rescatan profesor y huyen secuestradores (24-11-89)

AJ108 Matan a profesora en frente de sus alumnos (29-01-91)

AJ109 Sicarios siembran terror entre los maestros (30/01/91)

AJ110 Descubren tráfico de nombramientos (13/02/91)

AJ111 Atentado contra dos profesores (22/02/91)

AJ112 Rechazan tráfico de nombramientos (22/02/91)

AJ113 Asesinado ayer otro maestro en Medellín (27/02/91)

AJ114 Conmoción por crimen de dos alumnos y un maestro (27/02/91)

AJ115 En plena clase asesinan a profesor de primaria (06/03/91)

AJ116 Asesinan a dos profesores en Pereira (24/03/91)

AJ117 Piden al procurador pronunciarse sobre el asesinato de profesores $(02 / 04 / 91)$

AJ118 Asesinan a maestro y a detective del DAS (09/04/91)

AJ119 Por amenazas, se van profesores de Berbeo (03/05/91)

AJ120 Antioquia: asesinados 3 educadores (14/06/91)

AJ121 El magisterio antioqueño, silenciado por inseguridad (18/07/91)

AJ122 Asesinado ayer otro maestro en Antioquia (30/07/91)

AJ123 Maestros protestan por crímenes (31/07/91)

AJ124 Asesinado maestro en Casanare (27/08/91)

AJ125 Amenazas del magisterio (07/09/91)

AJ126 Asesinada otra educadora ayer en Medellín (28/09/91)

AJ127 Asesinado un educador en Bogotá (05/10/91)

AJ128 Medellín: matan a otro educador (17/10/91)

AJ129 Asesinaron a otro maestro en Medellín (01/11/91)

AJ130 Maestros buscan frenar violencia (08/11/91)

AJ131 Unidad para proteger a maestros amenazados (23/11/91)

AJ132 Maestros en estado de alerta (18/01/92)

AJ133 Asesinados otros dos maestros (21/01/92)

AJ134 Protección a maestros (23/01/92)

AJ135 Mataron al profe frente a 35 alumnos (02/09/93)

AJ136 La familia del profe quedó desprotegida (05/09/93) 
AJ137 Maestros en alerta (14/09/93)

AJ138 Maestro ciego ganó tutela a secretaría de educación (20/09/93)

AJ139 Aumentan amenazas contra maestros (04/10/93)

AJ140 Maestros amenazados: solución a vacantes (19/10/93)

AJ141 Asesinados 2 profesores en Caquetá (09/11/93)

AJ142 Asesinado profesor de música de la Universidad de Antioquia (22/11/93)

AJ143 Alumno mató a su profesor de matemáticas (08/12/93)

AJ144 Por amenazas, maestros no irían a clase (12/02/94)

AJ145 Descubren fraude por \$1.232 millones (17/02/94)

AJ146 Asesinato de maestra origina paro en Sucre (10/03/94)

AJ147 Tutela de maestro (23/03/94)

AJ148 Asesinados dos profesores en el nororiente (07/04/94)

AJ149 Asesinan a maestra y a su hija (03/05/94)

AJ150 Protección a maestros (01/07/94)

AJ151 Protección a maestros (02/07/94)

AJ152 Intimidan con cartas bomba a profesores en Medellín (25/11/94)

AJ153 Secretario de educación cobra por hacer nombramientos. Por educación, se sacan los cueros al sol (25/11/94)

AJ154 Maestros impugnan a Castillo (25/02/95)

AJ155 Asesinan a dos profesores (01/06/95)

AJ156 Posible falsificación por parte de maestros (05/07/95)

AJ157 En 9 años 302 maestros han sido asesinados (16/09/95)

AJ158 Profesores amenazados (01/11/95)

AJ159 Asesinan a maestra - Medellín (13/02/96)

AJ160 Siguen los asesinatos de profesores en Antioquia (14/02/96)

AJ161 Asesinada maestra - Medellín (13/02/96)

AJ162 Siguen los asesinatos de profesores en Antioquia (14/02/96)

AJ163 Protección a maestros (19/02/96)

AJ164 Niegan tutela a profesores de los Andes (13/03/96)

AJ165 El miedo quiere sacar a los maestros de Colosó (08/04/96)

AJ166 Habrá incentivos para los maestros en zonas críticas (19/04/96)

AJ167 Capturados maestros por masacre (17/05/96) 
AJ168 Asesinados 1 profesor y 2 concejales (17/07/96)

AJ169 Amenazados 570 profesores en el Cesar (19/09/96)

AJ170 Protesta en Antioquia por violencia contra docentes (29/11/96)

AJ171 Maestros en peligro (29/04/97)

AJ172 Amenazan a médicos y maestros (03/05/97)

AJ173 Paramilitares amenazan a 23 docentes (05/06/97)

AJ174 Matan a maestro en su casa, en Montería (21/06/97)

AJ175 Reubican a maestros (25/06/97)

AJ176 Estudian situación de maestros amenazados (04/07/97)

AJ177 Sin pistas de profesores secuestrados en montería (07/07/97)

AJ178 Personería sancionó a 24 maestros (11/07/97)

AJ179 Muertes de docentes debe acabar: sindicato mundial (15/07/97)

AJ180 Amenazan a 200 profesores (04/09/97)

AJ181 Quién ronda a los profesores (21/09/97)

AJ182 Investigan ascenso de 833 educadores en Cesar (20/08/98)

AJ183 Corte cita al banquillo a profesores diferentes (01/09/98)

AJ184 Asesinan a maestra frente a 42 niños (08/10/98)

AJ185 Guerrilla mató a educadores (28/04/99)

AJ186 Muerte en Uniantioquia (07/05/99)

AJ187 Reubican a maestros amenazados (09/11/99)

AJ188 Maestros con doble vinculación (08/08/2000)

AJ189 Maestros piden seguridad (14/09/2000)

AJ190 Profesores demandarán (03/10/2000)

AJ191 Asesinan a profesor de la Uniatlántico (07/10/2000)

AJ192 Irregularidades en ascensos de profesores (09/11/2000)

AJ193 Maestros falsificados (16/12/2000)

AJ194 Lo asesinaron por pensar diferente (18/05/2001)

AJ195 Asesinan a profesor. Foto (18/05/2001)

AJ196 Amenazan a profesores (11/09/2001)

AJ197 Maestros renunciarían por amenazas (15/11/2001)

AJ198 Investigan a 200 profesores (13/12/2001)

AJ199 Liberado profesor (23/02/2002)

AJ200 Ataque a docentes y escolares (10/10/2002) 
AJ201 ELN asesinó a la maestra de Cocorná (27/04/2003)

AJ202 Educadores denuncian amenazas (11/05/2003)

AJ203 Paras sacaron a profesores (06/06/2003)

AJ204 Investigan por crimen de profesores. Foto (05/10/2003)

AJ205 Investigan presunto carrusel de docentes (05/10/2003)

AJ206 Alumno dispara contra profesora en Pereira (15/11/2003)

AJ207 Investigan millonarios giros a maestros muertos (29/01/2004)

AJ208 Amenazados 42 educadores (14/07/2004)

AJ209 Olla podrida de docentes en chocó (28/07/2004)

AJ210 Acusan a 800 maestros de hacer trampa (27/08/2004)

AJ211 Maestros de la estafa (28/08/2004)

AJ212 En Cundinamarca pagaban hasta a maestros muertos $(21 / 10 / 2004)$

AJ213 Detenidos 11 maestros en Chocó. Foto (15/07/2005)

\section{Sueldos (SL)}

SL1 Dos meses de sueldo deben a profesores (07-01-77)

SL2 No hay quien pague las cesantía a los maestros (2-02-77)

SL3 Alza a los maestros (04-02-77)

SL4 Gobierno reajusta y reglamenta los sueldos del magisterio (08-02-77)

SL5 Bogotá está al día en pagos al magisterio (17-02-77)

SL6 Reajustado sueldo a maestros (26-03-77)

SL7 Definen recursos educativos (18-04-77)

SL8 'No hay plata para otro reajuste a magisterio' (05-05-77)

SL9 Nombran maestros sin respaldo presupuestal (09-05-77)

SL10 1600 millones vale reajuste de salarios de 160 mil educadores (15-05-77)

SL11 Aumento de sueldo para 2.290 maestros del D. E. (01-06-77)

SL12 Se corregirán errores en sueldos de maestros (05-06-77)

SL13 Escalas de remuneración para los maestros (06-06-77)

SL14 Pagos atrasados reclaman maestros (08-06-77)

SL15 Corregidas categorías de salarios del magisterio (30-06-77) 
SL16 \$15 mil millones a la educación (22-07-77)

SL17 Subsidio de educación rural no será salario (28-07-77)

SL18 \$29 millones para pago de maestros en Antioquia (29-07-77)

SL19 Pagan reajuste a maestros de Bogotá (08-08-77)

SL20 Nivelarán sueldo a maestros (04-09-77)

SL21 Hoy pagan a maestros de Bogotá (15-12-77)

SL22 Pagan a los maestros (23-12-77)

SL23 Mañana pagan a maestros de Bogotá (08-01-78)

SL24 Asegurado el pago a los profesores (04-02-78)

SL25 Hoy pagan a maestros del D. E. (07-02-78)

SL26 Gobierno apoya reajuste salarial del magisterio (12-02-78)

SL27 Aumentan sueldo a maestros de Cundinamarca (04-04-78)

SL28 Reajuste del 20\% para el magisterio (25-04-78)

SL29 \$115 millones vale aumento a maestros (22-07-78)

SL30 Anuncian pago al magisterio y... decreta paro nacional (28-07-78)

SL31 Cundinamarca cancela deudas al magisterio (s. f.)

SL32 Hoy pagan sueldo a educadores del D. E. (19-12-78)

SL33 \$170 millones para pago de maestros (21-12-78)

SL34 Entre el 15 y $30 \%$ reajuste a maestros (05-01-79)

SL35 Cundinamarca sin clase por demora de salarios (07-02-79)

SL36 En 1980 nivelarán los salarios de los maestros (30-04-79)

SL37 Maestros paran por demora en pagos; lista la plata, dice el ministro Lloreda (10-05-79)

SL38 Pagan reajuste a maestros (27-05-79)

SL39 Pagan reajuste salarial a los maestros (29-05-79)

SL40 Anuncia Lloreda Caicedo. Reajuste salarial al magisterio en $1980(22-10-79)$

SL41 Maestros retienen libretas para poder pedir pago de salarios (04-12-79)

SL42 Reajustan salarios y aplican nuevo escalafón (09-01-80)

SL43 \$2000 millones pagará gobierno al magisterio, por el nuevo escalafón (08-08-80) 
SL44 FF.AA. en retiro piden iguales sueldos que el magisterio (22-09-80)

SL45 Pagan hoy a maestros del D. E. (28-11-80)

SL46 'Ya les pagamos... por favor inicien clase' (04-02-81)

SL47 26\% suben los salarios de los maestros (10-02-81)

SL48 Aumentan salarios a maestros (13-02-81)

SL49 Panorama laboral. Suben salarios de comunicaciones y maestros: FECODE anuncia paro (13-02-81)

SL50 \$2 mil millones costó arreglo con maestros, Ultracum a la CGT (07-04-81)

SL51 Piden nacionalizar nómina de profesores (13-04-81)

SL52 Bogotá pagará sueldos de maestros del Mineducación (07-06-81)

SL53 La nación no asumirá cargos prestacionales de los maestros (22-06-81)

SL54 Asegurados \$435 millones para pago a los maestros (25-07-81)

SL55 Pagan desde hoy a 12 mil maestros; sigue paro en D. E. (28-07-81)

SL56 Se agotó dinero para los maestros (12-08-81)

SL57 Gran déficit para pagar a maestros (21-09-81)

SL58 Déficit de \$18 millones para pagar a maestros en 1982 (21-09-81)

SL59 Comienza pago a maestros; ayer no hubo clases (03-10-81)

SL60 Hoy pagan a maestros (03-11-81)

SL61 Gobierno comienza pago a maestros (06-02-82)

SL62 Gobierno expide nuevas normas para educación superior y congela nómina de magisterio (17-04-82)

SL63 Cundinamarca en marcha. Pagarán cesantías a maestros del departamento (22-11-82)

SL64 Cundinamarca en marcha. Pagarán deudas atrasadas al magisterio (02-03-83)

SL65 El D. E. no ha pagado a 800 maestros interinos (30-07-83)

SL66 Vistazo a Colombia. Maestros reciben 26 primas anuales (28-10-83) 
SL67 Trasladan \$70 millones para pago de maestros (01-12-83)

SL68 No han pagado sueldo a los educadores (20-12-83)

SL69 Pagarán a maestros desde hoy (20-12-83)

SL70 Pagan prima a maestros en Antioquia (23-12-83)

SL71 Por falta de pagos maestros se niegan a trabajar el lunes 6 (03-02-84)

SL72 Listo el pago de maestros (05-02-84)

SL73 Fijan escala salarial para el magisterio (01-03-84)

SL74 Descuentan 2 días de sueldo a 140 mil maestros por paro (10-05-84)

SL75 \$30 millones para pagos a maestros (19-05-84)

SL76 Cuánto ganan los maestros (04-06-84)

SL77 Hoy pagarán quinquenios a maestros (09-07-84)

SL78 Suspenden traslados y comisiones a maestros (23-07-84)

SL79 Listo el sueldo de maestros (25-07-84)

SL80 Mil millones pagarán a los maestros del D. E. (01-09-84)

SL81 Pago de maestros está sujeto a decisión del Congreso:

Mineducación (26-09-84)

SL82 Hoy sábado pagan a los maestros (29-09-84)

SL83 Pagan a los maestros desde hoy (01-11-84)

SL84 No hay plata para pagar (04-12-84)

SL85 El lunes pagarán a maestros de Bogotá (08-12-84)

SL86 Garantizan el pago a jueces y los maestros (15-12-84)

SL87 Pagan a maestros sueldo y prima desde mañana (17 -12-84)

SL88 Comienza hoy pago a 180 mil maestros (19-12-84)

SL89 Pagarán a 1060 quinquenios a maestros (29-12-84)

SL90 Con paro se inició pago a maestros (05-03-85)

SL91 No se puede cumplir pago a maestros (15-05-85)

SL92 Lunes pagan a maestros (29-07-85)

SL93 \$28 millones al magisterio de Chocó (25-08-85)

SL94 Retraso en nómina de educadores (20-12-85)

SL95 Otorgan aumento a docentes (08-01-86)

SL96 Salarios de maestros van de \$20.890 a \$103.130 (14-01-86)

SL97 La nación asumió pago de prestaciones de maestros (31-01-86) 
SL98 Hoy, pago a maestros por ascensos (13-02-86)

SL99 Asegurado pago a maestros (07-03-86)

SL100 Sin el retroactivo pagarán hoy a maestros (s. f.)

SL101 Dice Mineducación: 'Pagaremos \$14 mil millones pero no por presión de paro' (08-05-86)

SL102 Listos \$11 500 millones para pago a maestros (14-05-86)

SL103 Hoy pagan a magisterio distrital (22-05-86)

SL104 Hoy pagan subsidio a maestros (26-06-86)

SL105 La corte refrenda escala salarial de los maestros (19-07-86)

SL106 Afirma Marina de Eusse: \$27.531 millones debe

Mineducación a maestros (11-09-86)

SL107 Por falta de giro de Minhacienda no se pagó a los maestros (14-12-86)

SL108 Después de tres meses pagan a profesoras (07-03-87)

SL109 Proyecto del Gobierno para pagar a maestros (16-08-87)

SL110 Si no se les cancela prima de navidad, profesores no entregarán calificaciones a los alumnos (25-11-88)

SL111 Urge cancelación de prestaciones atrasadas. En paro 25 mil maestros de Antioquia (10-04-89)

SL112 Autorizado el alcalde. Pagarán las deudas a 13 mil maestros (05-08-89)

SL113 \$2 352 millones para los maestros (23-12-89)

SL114 ¿Quién responde por los pensionados? 1.700 maestros sin nadita qué comer... (12/10/90)

SL115 En Bolívar recibirán 32 millones de pesos. Autorizan pago de horas a maestros $(03 / 12 / 90)$

SL116 Piden pago oportuno (15/12/90)

SL117 Giro a maestros (12/01/91)

SL118 Pagan sueldos atrasados (13/02/91)

SL119 Congelan nómina (25/05/91)

SL120 A través del sistema bancario se pagará al magisterio (07/06/91)

SL121 Nueve meses sin sueldo (13/06/91)

SL122 Maestros y gobierno en desacuerdo sobre deuda (21/06/91) 
SL123 El estado pagará \$15 mil millones a los maestros (19/07/91)

SL124 Gobierno garantizó pago de deudas a 2.200 educadores $(31 / 07 / 91)$

SL125 Pago a maestros (06/08/91)

SL126 Agilizan pagos a maestros (13/12/91)

SL127 No hay plata para pagarles sueldos (26/05/92)

SL128 Les van a pagar (18/07/92)

SL129 Temporales: a clase sin sueldo (18/07/92)

SL130 Concejo decidirá el pago de los temporales: 92 (05/08/92)

SL131 Incierto el pago a temporales (06/08/92)

SL132 Acuerdan pago a temporales (27/08/92)

SL133 Se salvó el pago a los temporales (02/09/92)

SL134 Pagan sueldos a maestros (29/09/92)

SL135 Pago a temporales (28/10/92)

SL136 Dinero para maestros (04/12/92)

SL137 Pagan a maestros (16/12/92)

SL138 Los temporales pasan a la nómina (30/01/93)

SL139 Reparos a pago de nómina educativa (02/02/93)

SL140 Sectorizan pago a maestros (09/02/93)

SL141 Doble pago (21/06/93)

SL142 Pago a maestros (10/09/93)

SL143 Pagan a maestros (28/09/93)

SL144 A partir de mañana pagan a maestros en Cundinamarca $(21 / 12 / 93)$

SL145 Maestros, sin prima ni sueldo (21/12/93)

SL146 Maestros piden aumentos (10/02/94)

SL147 Pagan a los maestros (08/03/94)

SL148 Plata a maestros (11/03/94)

SL149 Pagos a maestros (07/05/94)

SL150 Listos cheques de escalafón de maestros (07/05/94)

SL151 Catedráticos: taxímetro de tarifa baja (09/05/94)

SL152 Pago a profesores (18/07/94)

SL153 Profesores económicos (01/08/94) 
SL154 Dinero para maestros (08/10/94)

SL155 Sueldos atrasados (28/10/94)

SL156 Sin reajuste, maestros (15/01/95)

SL157 Plata de salarios para profesores (17/03/95)

SL158 Investigan pago de maestro (08/05/95)

SL159 Maestros privados no deben ganar menos que públicos (08/06/95)

SL160 Habrá \$35.000 millones para docentes (19/07/95)

SL161 El FIS dio plata a docentes (14/08/95)

SL162 Reajuste a maestros será de 25\% (18/01/96)

SL163 Estímulos a maestros de zonas rojas (21/04/96)

SL164 Protesta de docentes de la Tadeo Lozano por sueldos (24/04/96)

SL165 Pagarían salarios atrasados a los maestros en el Huila (09/05/96)

SL166 Incentivos a maestros (30/07/96)

SL167 Maestros, a cobrar (31/07/96)

SL168 Descontarían salarios a 4.000 educadores (03/10/96)

SL169 Retrasan pago de maestros (19/01/97)

SL170 Docentes mal remunerados y con trabajo de tiempo parcial $(29 / 09 / 97)$

SL171 Consejo de Estado ordena el pago a profesores preescolares $(19 / 12 / 97)$

SL172 Maestros de U. Públicas piden más sueldo (15/02/98)

SL173 Extraviados \$123 millones para pago de profesores (21/03/98)

SL174 Que les paguen. Foto noticia (04/09/98)

SL175 Los pesos de los maestros (18/09/98)

SL176 Maestros sin plata (26/09/98)

SL177 La otra nómina de los maestros estatales (27/03/99)

SL178 Sueldos de maestros, por ascensor (19/10/99)

SL179 A maestros que paren no se les pagará (07/06/2000)

SL180 Profesores embargan cuentas (14/06/2000)

SL181 Agilizarán pago a los maestros (13/09/2000)

SL182 Fugas en ascensos y pagos a profesores (06/12/2000)

SL183 Aumento a los maestros (15/05/2001) 
SL184 Enredos por pago a maestros (11/07/2001)

SL185 Pagarán a profesores (15/07/2001)

SL186 Revolcón salarial en el magisterio (10/01/2002)

SL187 Pagan tarde a los maestros (29/09/2002)

SL188 Profesores, sin plata (16/12/2002)

\section{Aspectos Académicos (AA)}

AA1 El problema de La Nación. Profesores diagnostican el mal (10-05-77)

AA2 Profesorado de bachillerato convoca pleno (30-03-77)

AA3 Congreso de educadores (14-07-78)

AA4 Avanza capacitación a distancia, de maestros (28-08-78)

AA5 Foro latinoamericano de educación en Cali (04-12-78)

AA6 Cumbre nacional para estudiar reformas a primaria y bachillerato (12-02-79)

AA7 Encuentro de profesores de biología (16-08-79)

AA8 \$60 millones dona Alemania para capacitar docentes (25-04-80)

AA9 Capacitan al magisterio de Cundinamarca (18-08-80)

AA10 Maestros, ¡a estudiar! (20-10-80)

AA11 Congreso de profesores de biología y química (24-10-80)

AA12 Convocados los maestros a curso de capacitación (04-06-81)

AA13 Capacitación de maestros, hoy por TV. (10-11-80)

AA14 Muro estudiantil. Congreso Nacional de profesores de español (12-10-81)

AA15 Crean comité de docentes (20-10-81)

AA16 En Cundinamarca. Programa piloto para capacitar profesores (29-01-82)

AA17 Cursos para ascenso, a maestros (20-05-82)

AA18 Centro para docentes (20-07-82)

AA19 Vistazo a Colombia. Ni siquiera profesores (16-08-82)

AA20 Encuentro de educadores (09-09-82)

AA21 Muro estudiantil. Seminario para profesores de cuestiones científicas (18-09-82) 
AA22 Centro para docentes (20-07-82)

AA23 Lanzan manual para educadores (05-11-82)

AA24 Seminario de capacitación a profesores (22-11-82)

AA25 Encuentro de estudiantes y profesores de ciencias (30-06-83)

AA26 Pleno de educadores en 11 y 12 de agosto (19-07-83)

AA27 Cundinamarca en marcha. Entregan programa de capacitación docente (26-09-83)

AA28 Muro de estudiantes. Talleres para profesores (07-10-83)

AA29 Pleno de educadores en Bogotá (12-01-84)

AA30 Capacitan a profesores de filosofía (13-08-84)

AA31 Nuestra escuela está anquilosada: educadores (30-11-84)

AA32 Cambios en la formación de maestros (02-02-87)

AA33 Los maestros se examinan (16-08-87)

AA34 Programa para educadores colombianos (21-11-87)

AA35 El plan de la universalización de la educación. Ayudas educativas para estudiantes y maestros (19-11-88)

AA36 La casa Silva en Bogotá. Poesía para profesores y estudiantes (25-01-89)

AA37 Jornadas de autoevaluación de la educación. Los maestros tienen esperanzas (19-11-89)

AA38 Inician hoy la capacitación de maestros urbanos (31-10-89)

AA39 Cómo formar a los formadores (25/11/90)

AA40 Examen a maestros (08-01-91)

AA41 Los profesores también se rajan (15/05/92)

AA42 Profesores, al colegio (28-11-92)

AA43 Catedráticos colombianos lanzan tratado pediátrico (08/11/92)

AA44 Congreso de profesores normalistas (07/10/92)

AA45 Los temporales no se rajan (11/11/92)

AA46 Maestros se actualizan (29/01/93)

AA47 Se rajan los maestros (31/05/93)

AA48 De evaluadores a evaluados (14/06/93)

AA49 Capacitación a maestros (19/07/93)

AA50 Capacitación para maestros de grado cero (28/12/93) 
AA51 Educación sexual para maestros (22/04/94)

AA52 A formar educadores (05/07/94)

AA53 Un encuentro con el profesor Karl Popper (07/10/94)

AA54 A capacitar docentes (10/10/94)

AA55 Formación de maestros, a la carta (08/11/94)

AA56 Inglés para maestros oficiales (02/05/95)

AA57 Docentes ¡a estudiar! (24/04/95)

AA58 Grado en derechos humanos a 500 maestros (17/06/95)

AA59 Cien docentes fueron becados (22/06/95)

AA60 Cuál es el maestro que necesita el país (07/11/95)

AA61 Encuentro de profesores (22/11/95)

AA62 Becas en Canadá para profesores universitarios (19/02/96)

AA63 Una pregunta corchadora para una de las mejores profesoras (24/05/96)

AA64 Maestros oficiales estudian inglés en E. U. (11/06/96)

AA65 A prueba, maestros oficiales (30/06/96)

AA66 Docentes oficiales, de examinadores a examinados (05/08/96)

AA67 Aplazan las pruebas de estado para maestros (15/08/96)

AA68 Congreso de maestros (19/10/96)

AA69 Con becas y préstamos, maestros celebraron su día (16/05/97)

AA70 Programa para capacitar maestros (24/07/97)

AA71 Profe, prepárese en valores (22/10/97)

AA72 Profesores, jal tablero! (18/10/98)

AA73 Maestros: a examen en noviembre (23/04/99)

AA74 Aplazan evaluación de profesores (23/09/99)

AA75 A evaluar docentes (10/05/99)

AA76 Evaluar a los maestros (22/05/99)

AA77 Santillana convoca maestros (08/06/99)

AA78 En busca de mejores profesores (25/08/99)

AA79 Maestros se rajan en clases (12/06/2000)

AA80 Maestros también se rajan (12/06/2000)

AA81 Cursos a maestros, nunca en vacaciones (24/06/2000)

AA82 Maestros necesitan renovarse (09/12/2000) 
AA83 Los docentes, jal tablero! (15/05/2001)

AA84 Encuentro de profesores (07/09/2001)

AA85 Profesores: ¡a hablar inglés! (19/06/2002)

AA86 Docentes se capacitan en el exterior (19/07/2003)

AA87 Docentes desobedecen evaluación (26/11/2003)

AA88 Maestros no quieren ser evaluados (26/11/2003)

AA89 Becas para maestros (04/07/2004)

AA90 Red internacional de profesores (15-8-04)

AA91 195 mil maestros presentarán examen (13/11/2004)

AA92 Inglés: profesores van de regreso a la escuela (28/11/2004)

AA93 Maestros, al tablero (17/12/2004)

AA94 Al tablero, los profesores del silencio (23/12/2004)

AA95 Hoy, examen a maestros (16/01/2005)

AA96 Maestros hicieron examen, a pesar del boicot. Foto leyenda $(17 / 01 / 2005)$

AA97 El difícil camino de la evaluación de docentes (24/01/2005)

AA98 Necesidad de preparar a los maestros (26/01/2005)

AA99 No todos los rajados son maestros (11/02/2005)

AA100 Rajazón de aspirantes a maestros en Sincelejo (11/02/2005)

AA101 A pesar de los disturbios, miles de docentes presentaron los exámenes (17/01/2005)

AA102 Talleres para profesores (03/04/2005)

\section{Leyes, reglamentos y estatutos (LY)}

LY1 Listos seis decretos sobre educación (08-01-77)

LY2 Listos cuatro decretos sobre educación pública (10-01-77)

LY3 Aprobado el estatuto docente (21-01-77)

Estatuto docente para el magisterio (21-01-77)

LY5

Rectores desconocen decreto de pensiones (24-01-77)

LY6 Sobre un estatuto (24-01-77)

LY7 El escalafón (02-02-77)

LY8 El Nuevo estatuto docente prohíbe a ciegos enseñar (07-02-77) 
LY9 Por qué el estatuto docente es regresivo (08-02-77)

LY10 Paro o derogatoria del estatuto piden educadores (10-02-77)

LY11 La constitución prohíbe paro de maestros (11-02-77)

LY12 Demandado ante la corte el Estatuto Docente (02-04-77)

LY13 Dos demandas al Estatuto de docentes (04-04-77)

LY14 Pliego de enmiendas al estatuto docente (30-05-77)

LY15 Abolido año de práctica para maestro bachiller (08-06-77)

LY16 Supervisores. Rechazan estatuto docente (12-06-77)

LY17 Con el escalafón (21-06-77)

LY18 Un reajuste (24-06-77)

LY19 Separar escalafón y estatuto docente piden educadores (23-07-77)

LY20 Estatuto docente será modificado (03-09-77)

LY21 Vigente estatuto docente (22-01-78)

LY22 Reunión del magisterio por estatuto (24-01-78)

LY23 En estado de sitio no se aplicará estatuto docente (28-01-78)

LY24 No se aplicará estatuto docente, dice gobierno (03-02-78)

LY25 Descartan nuevo estatuto docente en este gobierno (07-04-78)

LY26 Urge salir del impase del estatuto docente (23-04-78)

LY27 El escalafón (29-07-78)

LY28 Estatuto docente público y privado Ilevan al Congreso (15-08-78)

LY29 Nuevo estatuto docente proyecta el gobierno (06-09-78)

LY30 Se salvó reforma educativa (16-12-78)

LY31 Cambios en el régimen del magisterio (14-02-79)

LY32 Nuevo estatuto docente. Escalafón único con 13 grados (15-02-79)

LY33 Nuevo estatuto docente anuncia Mineducación (22-04-79)

LY34 Anuncia Lloreda. Estatuto docente para dignificar la docencia (16-05-79)

LY35 Listo el estatuto docente (09-07-79)

LY36 Intensifican labor por estatuto docente (19-07-79)

LY37 Estatuto docente, en recta final (23-07-79) 
LY38 En agosto se expide estatuto docente (26-07-79)

LY39 Maestros, en alerta por nuevo estatuto (31-08-79)

LY40 El 20 expedirán nuevo estatuto para maestros (10-09-79)

LY41 Gran acuerdo sobre estatuto cierran maestros y gobierno (13-09-79)

LY42 Hoy expiden nuevo estatuto docente (19-09-79)

LY43 Afirma Turbay. Estatuto Docente, fruto de política avanzada (20-09-79)

LY44 Criterios liberales. El estatuto docente (24-09-79)

LY45 Estatuto para la docencia (27-09-79)

LY46 Estatuto docente (21-10-79)

LY47 Rechazan reforma (26-10-79)

LY48 Expedido estatuto docente (31-10-79)

LY49 Decreto reglamentario del estatuto docente (01-11-79)

LY50 Normas de asimilación al escalafón (17-11-79)

LY51 Reglamentación del gobierno al Estatuto Docente son violatorias: FECODE (22-11-79)

LY52 Alerta el magisterio por fallo de la Corte (09-12-79)

LY53 Jamás se ha suspendido carrera docente, dice el Consejo de Estado (s. f.)

LY54 Reajustes múltiples en el magisterio (24-1-80)

LY55 Centenaria ley tumba otra sobre el escalafón (06-06-80)

LY56 Amplían plazo para escalafón en el magisterio (14-06-80)

LY57 Hasta octubre amplían plazo de asimilarse a escalafón docente (23-06-80)

LY58 Iglesia contra Estatuto Docente (25-06-80)

LY59 Hasta diciembre tendrán plazo para asimilación de maestros a escalafón (01-11-80)

LY60 Reglamentan ascensos de personal docente en el país (07-02-81)

LY61 Reglamentan ascensos de personal docente en el país II (09-02-81)

LY62 Otros tres mil maestros al escalafón (04-03-81) 
LY63 Prohíben enganche urbano de maestros (31-10-81)

LY64 Nuevo reglamento educativo. Fijan ruralia obligatoria de dos años para maestros (25-01-82)

LY65 Gobierno decretó nueva reforma a controles para la educación pública (26-01-82)

LY66 Reforma educativa II. Prohíben traslado de bachilleres a ciudades (27-01-82)

LY67 Fallos y fallas. Ordenan reconocer ascensos en magisterio para antigüedad (16-12-82)

LY68 En peligro reivindicaciones alcanzadas por los maestros (23-08-82)

LY69 Cae compatibilidad de pensión y sueldo para profesores y maestros (30-08-83)

LY70 Concepto del Consejo de Estado. Destitución de docentes que figuren en lista (03-03-84)

LY71 Por una solución para los educadores (10-05-84)

LY72 Gobernadores darán permiso a los maestros (01-03-86)

LY73 Anuncia Mineducación: Magisterio tendrá nuevo régimen disciplinario (23-06-86)

LY74 Sanciones a maestros serán más drásticas (26-6-86)

LY75 Frenados ascensos de los maestros de bachillerato (25-05-88)

LY76 Sanciones por incumplimiento de normas del Estatuto

Docente (02-11-88)

LY77 Nueva reestructuración del Ministerio de Educación.

Sancionada ley que reglamenta el manejo del personal docente (21-02-89)

LY78 Reglamentan ley sobre descentralización educativa. Los alcaldes administrarán el personal docente en el país (09-08-89)

LY79 Unificarán el régimen de los maestros. Proyecto de ley para crear fondo de prestaciones del magisterio (01-09-89)

LY80 Proyecto de prestaciones pasa a plenaria. Los maestros, a punto de contar con su Fondo (07-11-89)

LY81 Escalafón (19/11/90)

LY82 Por fin, acuerdo con los temporales (15/08/92) 
LY83 Maestros internacionales vieron ley de educación (05/04/93)

LY84 Reanudan debate sobre ley de educación (29/04/93)

LY85 Reformas a Secretarías de Educación (09/07/93)

LY86 Maestro ciego ganó tutela a secretaría de educación (20/09/93)

LY87 Tutela de maestro (23/03/94)

LY88 Pliegos a profesores (06/05/94)

LY89 Avalan primas a los maestros ocasionales (19/01/96)

LY90 Acuerdo gobierno-maestros (07/03/96)

LY91 Nuevo régimen salarial para los profesores (10/01/2002)

LY92 Cambian régimen salarial de maestros (23/06/2002)

LY93 Maestros, a marchar con nuevas leyes (23/06/2002)

LY94 No aplicarla, no firmarla (26/11/2003)

\section{Reconocimientos (R)}

R1 Gobierno condecora a educadores (20-07-77)

R2 Homenaje a un educador (28-01-78)

R3 25 años de maestra (05-07-78)

R4 Escogidos los mejores maestros y alumnos de las escuelas de Bogotá (11-10-78)

R5 Homenaje hoy a 11 educadores (28-11-78)

R6 Darío Samper: 40 años de poeta y 17 como educador (18-12-78)

R7 Crean distinción para educadores (26-02-79)

R8 Homenaje a maestros pide el gobierno (12-05-79)

R9 Elogio del maestro (15-05-79)

R10 El día del maestro (16-05-79)

R11 Distinción a educadores (20-05-79)

R12 Distinción a veterano educador (20-06-79)

R13 Ernesto Bein. El 'Profe' de muchos colombianos (s. f.)

R14 Inmanencia cineraria. Profesor Edmundo Rico (03-03-80)

R15 Condecoran a 7 educadores en Bogotá (22-03-80)

R16 Gobierno condecora a 106 educadores (23-05-80)

R17 Gobierno condecora a maestros y colegios por labor educativa (12-09-80) 
R18 Homenaje a educadores (05-05-81)

R19 La Secretaria de Educación condecora hoy a 223 maestros (15-05-81)

R20 Homenaje a educadores (25-05-81)

R21 Cajicá exalta labor de cuatro educadores (08-06-81)

R22 Homenaje a la memoria del profesor Arturo Aparicio en San José (17-10-81)

R23 Carlos Federico, el maestro del año (14-05-82)

R24 Día del maestro (21-05-82)

R25 Mañana, día del educador (14-05-83)

R26 En día del educador, condecorados 147 maestros (17-05-83)

R27 Homenaje a educadores (08-09-83)

R28 Recuerdo del gran educador (08-10-83)

R29 Concurso valores humanos Pintuco. Religiosa y maestra comparten el premio (05-12-83)

R30 El profesor Núñez Navas (02-02-84)

R31 Centenario de un educador Chiquinquireño (30-03-84)

R32 80 años de una educadora (23-09-84)

R33 Educadores distinguidos (09-02-85)

R34 Reconocimiento a un maestros (07-03-85)

R35 El profesor Ospina era el líder de la comunidad (05-07-85)

R36 Un colombiano, mejor profesor del año en E. U. (27-02-87)

R37 Medallas a maestros de Bogotá (22-04-87)

R38 Homenaje a un educador (08-08-88)

R39 El día del maestro (15-05-89)

R40 Hoy día nacional del maestro. Un beso para el «profe» Henry (15-05-89)

R41 Condecoradas 11 personas ayer en el día del educador (16-05-89)

R42 Condecoran a los mejores 10 maestros (12/06/91)

R43 Reconocimiento a 90 maestros del externado (25/08/92)

R44 Día del maestro (14/05/93)

R45 Premiarán a profesores (18/05/93)

R46 Día del maestro (14/05/93) 
R47 Premios en educación (07/06/93)

R48 Profesores destacados (20/12/93)

R49 Título de profesor honorario (28/03/94)

R50 Mineducación condecora a 35 maestros de todo el país (20/05/94)

R51 Día del maestro (15/05/95)

R52 Los profes más pilos y dedicados del país (23/05/94)

R53 Exaltan labor de los maestros (15/12/95)

R54 Homenaje a 46 docentes del país (16/12/95)

R55 Los triunfos del alumno son del maestro (18/12/95)

R56 Una maestra recordada en la tierra del olvido (26/03/96)

R57 Premian a mejores escuelas y docentes (10/05/96)

R58 El Tiempo destacará los mejores maestros (13/05/96)

R59 Homenaje a los maestros (15/05/96)

R60 Gloria Canro, una maestra ejemplar (15/05/96)

R61 Cómo es tu maestro favorito 15/05/96

R62 Los 881 maestros que más alumbran 18/05/96

R63 Un 10 a los mejores profes (08/10/98)

R64 El mejor maestro (11/10/98)

R65 Profe, mi querido profe... (13/10/98)

R66 Los profesores necesitan aprecio y respeto (16/05/99)

R67 Así son los maestros del país (18/06/99)

R68 Premio para los maestros pilos (24/10/99)

R69 Un maestro que enseña para la vida (24/10/99)

R70 Premio compartir (15/05/2001)

R71 Profesores ilustres (10/06/2001)

R72 Premian a maestros héroes (15/05/2002)

R73 Antonieta, la maestra huitoto (12/05/2003)

R74 Premiarán a maestros (20/02/2003)

R75 Profesión, maestro (12/05/2003)

R76 Homenaje a los profesores (16/05/2003)

R77 Melva, la mujer que cambió a Pensilvania (07/09/2003)

R78 Premio al maestro 2004 a dos profesores (08/10/2004)

R79 Una venia a los grandes maestros (10/10/2004) 
R80 Maestros, los héroes de Saramago (23/11/2004)

R81 Maestros ilustres a España (27/02/2005)

R82 Maestra innovadora (23/04/2005)

R83 ¡Salud! Docente (13/05/2005)

\section{Curiosidades (CU)}

CU1 Como no sirvió de profesor de música... ¡lo nombraron rector! (12-08-81)

CU2 De emoción murió maestro de Betancur (09-08-82)

CU3 Un burro se come nómina de maestros (13-06-83)

CU4 Con bingo le pagarán a profesores en colegio de Suba (21-09-85)

CU5 Los maestros son «cachaquitos» (4-11-89)

CU6 Técnica nipona para docentes colombianos (10/09/90)

CU7 Alumnos cobraban sueldos (27/03/91)

CU8 Lanzan libro ambiental para maestros (21/07/93)

CU9 Perdió el año por no llevar periódico a clase (12/07/94)

CU10 Profes, buscando visa para un sueño (27/06/95)

CU11 Profesores con luz (04/08/95)

CU12 Pachito, un maestro bendito entre las mujeres (17/06/96)

CU13 La maestra más seductora (19/08/2001)

CU14 Profes de Japón, golpeados (26/08/2001)

CU15 Profe, en el lugar equivocado (26/09/2001)

CU16 La NASA recluta profesores. Foto (19/05/2002)

CU17 Una profe de 12 años (29/09/2002)

CU18 Una profe de 12 años. Foto leyenda (29/09/2002)

CU19 Coquito nació de la idea de un profesor francés (20/02/2005)

CU20 Cuba exporta maestros a Colombia (17/06/2005)

CU21 Cuba exporta maestros a Colombia (17/06/2005)

\section{Bienestar social (BS)}

BS1 Financiacoop apoya el nuevo centro docente (03-02-78)

BS2 Convenio para vivienda del magisterio en Cundinamarca (06-08-83) 
BS3 1.400 maestros sin atención médica ni prestaciones; D. E. culpa al Mineducación (12-5-81)

BS4 BCH financia viviendas a educadores (25-01-85)

BS5 Entregan viviendas a maestros (21-07-87)

BS6 Construirán un gran centro vacacional para educadores (24-04-89)

BS7 Maestros sin ayuda médica (01/02/91)

BS8 Magisterio sin salud (15/04/92)

BS9 Vivienda para educadores (09/08/93)

BS10 Programa de vivienda para maestros del D. C. (27/08/93)

BS11 Constructodo entrega vivienda para profesores (11/12/93)

BS12 Cofinanciación a maestros (22/03/94)

BS13 Predios para maestros (29-02-96)

BS14 Profesores se quejan del servicio médico (20/04/96)

BS15 Apoyo a profesores (15-03-02)

BS16 Por el bienestar docente (12/10/03)

BS17 Los docentes merecen un buen servicio médico (13/05/05)

\section{Actores sociales}

\section{Los maestros (M)}

M1 Crítica situación afrontan los maestros del Vaupés (19-03-77)

M2 Se agudiza división entre los profesores de bachillerato (06-06-77)

M3 El profesor especializado (31-07-77)

M4 Una ciega, pedagoga musical (02-08-77)

M5 Los educadores somos culpables (16-08-77)

M6 4 exigencias presentan educadores (19-09-77)

M7 Maestros intentaron toma de gobernación en Bucaramanga (22-09-77)

M8 Maestra del Quindío arrestada con coca (27-08-78)

M9 Freno al despilfarro de profesorado (05-10-78)

M10 En Boyacá. Analfabetismo en cuna de maestros (30-03-79)

M11 Los maestros... (30-03-79)

M12 ¿Cuál es el suyo? Tipología del profesorado (07-05-79) 


$\begin{array}{ll}\text { M13 } & \text { Los maestros (15-05-79) } \\ \text { M14 } & \text { Debates sobre maestros (22-05-79) } \\ \text { M15 } & \text { Quiénes son los maestros (12-07-79) } \\ \text { M16 } & \text { Reclama por maestra (10-01-80) } \\ \text { M17 } & \text { Los maestros pidieron... (02-02-80) } \\ \text { M18 } & \text { El profesor (22-03-80) } \\ \text { M19 } & \text { Maestros ratifican paro (25-03-80) } \\ \text { M20 } & \text { Maestros politizados (27-05-80) }\end{array}$

M21 Revocar medida que recorta vacaciones, piden los docentes (22-06-80)

M22 Inquietudes de un profesor (12-12-80)

M23 El 'Profe' puertas para adentro (22-12-80)

M24 El maestro de los Chibchas (22-01-81)

M25 Los maestros (05-02-81)

M26 Profesores denuncian hostilidad policial (25-05-81)

M27 Desconcierto entre padres y maestros (22-07-81)

M28 'Los maestros solo trabajan 4 horas' (14-08-81)

M29 Faltan maestros y empleos para los bachilleres (14-09-81)

M30 Marcha del pan. Masiva vinculación de educadores (22-09-81)

M31 El conflicto del Perdomo. Encerrados con Ilave en los claustros maestros y alumnos (14-10-81)

M32 La ciudad y la gente. Los profesores (09-11-81)

M33 Aclaración de maestros de Tibabuyes (02-12-81)

M34 Mal profesor (25-02-82)

M35 Maestros pobres (17-03-82)

M36 Los maestros (31-03-82)

M37 Ilegales, 11 mil maestros del distrito (29-4-92)

M38 Ganadores de concurso de profesores piden que garanticen nombramientos (12-05-82)

M39 Maestros se quejan de mala atención médica (19-08-82)

M40 Destituyen doscientos profesores 'piratas' (01-10-82)

M41 Regaladme unos minutos. Todavía es tiempo, profesores (29-10-82) 
M42 Maestros en estado de alerta (01-02-83)

M43 Maestros y alumnos (01-06-83)

M44 Maestros jubilados del Norte de Santander (22-07-83)

M45 Los profesores (20-08-83)

M46 De los educadores (06-10-83)

M47 Profesores careros (23-11-83)

M48 Vistazo a Colombia. Denuncian despidos en magisterio (25-11-83)

M49 Quién fuera profesor (26-01-84)

M50 Denuncian a educadores (02-03-84)

M51 Los maestros (03-03-84)

M52 300 maestros en incapacidad agravan la crisis escolar (06-03-84)

M53 Maestros amenazan con paro nacional (12-04-84)

M54 El profesor Socarrás académico (30-04-84)

M55 Maestros politizados (08-05-84)

M56 Maestra rechaza jubilación mayor a \$200.000 mensuales (16-02-85)

M57 Acusada la famosa jubilación de maestra (20-02-85)

M58 Una escuela donde los maestros son soldados (25-02-85)

M59 Los maestros (26-04-85)

M60 Educación y maestros (09-05-85)

M61 Los maestros (11-05-85)

M62 Muchos maestros no han colaborado con Camina (16-08-85)

M63 Escuelas públicas (3). Aulas vacías y maestros ausentes (04-09-85)

M64 Maestra destituida (06-09-85)

M65 Los maestros (21-12-85)

M66 Detenido maestro homicida (25-01-86)

M67 Negocio de un profesor (03-03-86)

M68 Denuncia de El Tiempo. Suspenden a maestros inmorales; se reformará el estatuto docente (27-05-86)

M69 Sancionan a profesor que violó a una niña (26-06-86)

M70 Siguen proceso contra un maestro que violó a niña (09-08-86)

M71 Colas de maestros (28-08-86) 
M72 Sancionan a 7 maestros por mala conducta (01-08-86)

M73 Piden libertad de profesora (01-09-86)

M74 Desórdenes en los FER. ¡Maestros muertos que pasan por vivos! (13-01-87)

M75

Maestros politizados (10-04-87)

M76

El día del maestro. Educadores nuevos para Escuela Nueva (22-04-87)

M77 ¿Quién le enseña a los maestros? (30-06-87)

M78 El grupo de teatro. Iniciativa que paró un profesor (18-08-87)

M79 El nuevo maestro frente al gran reto (07-02-88)

M80 Agitada semana en la educación. Sanción a maestros estudia el gobierno (30-04-88)

M81 Ser maestro (22-05-88)

M82 Un «profe» en la gobernación de Bolívar (07-06-88)

M83 Paralizado colegio de Barichara. Piden destituir profesores por homosexualismo y hurto (17-07-88)

M84 Cargos a profesor por abuso sexual (12-08-88)

M85 Otro de los obstáculos de la educación en el país. Los maestros están bajo el fuego (29-08-88)

M86 Profesor peligroso (08-12-88)

M87 Alcaldes y docentes (05-01-89)

M88 Por falta de pago de la caja de previsión, tres profesores morirían por falta de tratamiento médico (16-02-89)

M89 El personal docente (23-02-89)

M90 Maestros (09-05-89)

M91 Maestros (17-05-89)

M92 Advierte el contralor. Siguen vigentes los problemas con los maestros (01-06-89)

M93 Maestros elegibles (19-06-89)

M94 Cultura y maestros (05/10/90)

M95 Maestros que trabajan (17/09/90)

M96 Maestros temporales (01/02/91)

M97 Con los maestros (07/02/91) 
M98 Maestros (24/05/91)

M99 Elegir y ser elegidos, piden los educadores (15/06/91)

M100 Destitución a maestros (01/10/91)

M101 Analizarán la situación de los maestros (15/11/91)

M102 Maestros criticaron al alcalde y les formuló denuncia penal $(16 / 11 / 91)$

M103 Maestros (14/12/91)

M104 Renuncian profesores (26/03/92)

M105 Maestros (15/05/92)

M106 Solución al problema de los maestros en Usme (24/07/92)

M107 Maestros barajan el traslado (12/09/92)

M108 Los profesores tienen (20/10/92)

M109 Maestros liberales (21/11/92)

M110 Maestros convertibles (21/02/93)

M111 Profesores (22/02/93)

M112 Profesores (19/03/93)

M113 Profesores piden a Mockus renunciar (29/04/93)

M114 Profesores en asamblea (12/05/93)

M115 Un maestro nada ejemplar (19-05-93)

M116 Maestros (21/05/93)

M117 Los maestros (07/06/93)

M118 Los profesores que cumplieron (13/06/93)

M119 Solución a maestros (28/07/93)

M120 Profesores (26/08/93)

M121 Profesores contra directivos (16/12/93)

M122 Maestros al día en Nochebuena (22/12/93)

M123 Acuerdo con maestros de Cundinamarca (11/03/94)

M124 Más maestros (12/03/94)

M125 Más maestros (22/03/94)

M126 Maestros creativos (14-03-94)

M127 Maestra de primaria raja a la guerrilla (03/04/94)

M128 Hay que mirar a los profesores (13/04/94)

M129 Los maestros están de catre (01/05/94) 
M130 Maestros indígenas (25/07/94)

M131 Profesores de idiomas (16/08/94)

M132 Profesores investigadores (12/09/94)

M133 Maestros (19/10/94)

M134 Profesores en alerta (10/05/94)

M135 Profesores podrán hacer política (14/12/94)

M136 Profesores mal enseñados (17/04/95)

M137 Llegaron los profesores (23/04/95)

M138 Profesor organiza cabildo abierto (06/05/95)

M139 Maestros indígenas rajan a gobierno (23/05/95)

M140 Llamado a profesores (14/08/95)

M141 Maestros: sancionados y amenazados (19/02/95)

M142 Juguemos a que éramos el profesor ideal (15/05/95)

M143 Los maestros que se hacen imitar y querer (30/05/95)

M144 Paciencia de maestros (06/10/95)

M145 Los profesores están felices, pero... (05/11/95)

M146 La clave está en los maestros (27/11/95)

M147 Maestros le sacan la roja a Mockus (07/12/95)

M148 Profesores cubanos (22/02/96)

M149 Maestros crucificados. Foto noticia (16/03/96)

M150 Para maestros (26/04/96)

M151 No hubo lobby para elección de maestros (23/07/96)

M152 Niegan lobby para selección de maestros (24/07/96)

M153 Profesores chilenos (21/10/96)

M154 Maestros de inglés (18/11/96)

M155 Maestros no quieren cambios (15/03/97)

M156 Un grupo de profesores (08/05/97)

M157 Maestros deben investigar: IDEP (18/07/97)

M158 Maestros por la vida. Foto noticia (26/07/97)

M159 Organizan tres foros por la vida de los maestros del país (26/07/97)

M160 Los maestros (28/07/97)

M161 Profesores renuncian a ser jurados (08/08/97)

M162 Profesores de inglés, a E.U. (28/08/97) 
M163 Maestros oficiales viajan a Estados Unidos (29/08/97)

M164 Qué pasa con los profesores (29/09/97)

M165 Igualdad en ascenso para los docentes (10/10/97)

M166 Docencia (12/03/98)

M167 El debate sobre expulsión de profesores homosexuales (06/04/98)

M168 Si es maestro, no toque ni abrace a los estudiantes (29/05/98)

M169 Para docentes (16/06/98)

M170 Maestros gay se defendieron ayer en audiencia pública (02/09/98)

M171 Qué han ganado los maestros (05/09/98)

M172 Ponencia favorable a profesores gay (09/09/98)

M173 Sí a profesores homosexuales (09/09/98)

M174 Profesores de inglés (07/10/98)

M175 En sintonía con el maestro (22/05/99)

M176 Dónde están los buenos maestros (09/11/99)

M177 Formadores de nuevas generaciones (25/11/99)

M178 El maestro de hoy (05/03/2000)

M179 Profes no quieren goles (07/03/2000)

M180 Maestros no saben cómo evaluar (14/03/2000)

M181 Maestros, sin vacaciones (09/05/2000)

M182 Maestra con armadura de sindicalista (11/06/2000)

M183 Maestros, voces y silencios (20/06/2000)

M184 Maestros se rebelan por sueldos (07/09/2000)

M185 Educadores piden que siga proceso (25/09/2000)

M186 Vida de los profesores, en la pantalla chica (25/10/2000)

M187 Relevan a maestros de jurados (28/10/2000)

M188 Profesores hablan duro (05/11/2000)

M189 Profesores, con menos programas (09/11/2000)

M190 Profesores de la trampa (14/12/2000)

M191 Para profesores (28/01/2001)

M192 Maestros, por favor (14/03/2001)

M193 Profesores contra viento y marea (15/05/2001)

M194 Francia busca profesores (27/05/2001) 
M195 Montessori, no a profesores interinos (17/07/2001)

M196 Profesores diezmados por SIDA (05/08/2001)

M197 Maestro 1.0 sigue a la carga (12/08/2001)

M198 Inglaterra busca profesores (02/09/2001)

M199 A hacer fila, maestros (08/10/2001)

M200 Maestros inocentes. Foto (18/12/2001)

M201 Profes a declarar regalos (23/12/2001)

M202 Profesores de mente abierta (24-02-2002)

M203 Educadores, líderes y jóvenes (24/03/2002)

M204 Bourdieu y los profesores. Foto (28/04/2002)

M205 Maestros y pensionados (07/09/2002)

M206 La imaginación, a prueba de maestros (08/09/2002)

M207 No a maestros masones (15/09/2002)

M208 Docentes celebran en el exilio (05/10/2002)

M209 Maestros, a buscar niños (02/11/2002)

M210 Cocorná despidió a maestra (28/04/2003)

M211 Maestros, preocupados por la calidad (29/08/2003)

M212 Sordos serán profesores (16/09/2003)

M213 Profes, al borde de la locura (21/09/2003)

M214 Maestros oficiales, al borde de la locura (21/09/2003)

M215 Ser maestro en Colombia (18/11/2003)

M216 Críticas de profesores (28/08/2004)

M217 Profesores en el Reino Unido (12/09/2004)

M218 Vía crucis para unos profesores (22/10/2004)

M219 El dilema de los maestros provisionales (02/12/2004)

M220 La locura ronda a profesores (13-05-2005)

\subsection{Maestros como cifras (CF)}

CF1 Bajo nivel de maestros hay en Bogotá (08-01-77)

CF2 150 maestros asignará el distrito (08-02-77)

CF3 $\quad 70$ profesores de la UN también se retiran de la ASPU (12-02-77)

CF4 Normales carecen de educadores (17-12-77)

CF5 Solucionan problema de escuelas sin maestros (08-03-79)

CF6 Solicitud de maestros (20-03-79) 
CF7 Abren concurso para maestros, directores y supervisores del D. E. (09-10-79)

CF8 El Suroriente clama por maestros y más transporte (08-06-80)

CF9 Sobran maestros en las ciudades y faltan en el campo (22-01-81)

CF10 1.400 maestros sin atención médica ni prestaciones; D. E. culpa al Mineducación (12-05-81)

CF11 Resumen nacional. Piden nombrar maestros (31-03-82)

CF12 800 plazas de maestros estaban vacantes... y nadie lo sabía (09-03-83)

CF13 Piden profesores (12-04-83)

CF14 En educación. Sobran 20 mil maestros y hay un déficit de \$40 mil millones (28-05-83)

CF15 Con buena distribución sobrarían maestros en el país:

Mineducación (30-05-83)

CF16 Maestros en exceso (20-06-83)

CF17 Miles de estudiantes perjudicados por falta de maestros en Bogotá (12-08-83)

CF18 Solución de emergencia para cubrir plazas de maestros (13-08-83)

CF19 Profesores, transporte y vías pide la Gran Yomasa (05-09-83)

CF20 8 maestros amnistiados nombró la Secretaría de Educación del

D. E. (15-09-83)

CF21 No quieren mandar maestros (26-03-84)

CF22 Escuela cerrada por falta de maestra (09-04-84)

CF23 Paro estudiantil en colegio Distrital por escasez de maestros (11-04-84)

CF24 Nombraron 300 maestros interinos (19-02-85)

CF25 La Dorada pide maestros (08-03-85)

CF26 Faltan 189 maestros (s. f.)

CF27 200 maestros para el Suroriente (03-05-85)

CF28 Sin profesores dos escuelas de Zipaquirá (03-08 -85)

CF29 'En Mineducación ni siquiera se sabe cuántos son los maestros' (12-09-85) 
CF30 En educación oficial. 4 mil maestros para 350 cupos (01-10-86)

CF31 D. E. busca fondos para nombrar a 200 maestros (23-02-87)

CF32 Mineducación asumirá deudas al magisterio por \$50 mil millones (12-03-87)

CF33 Facultades para nombrar 2.000 maestros y construir 900 aulas pide el alcalde (08-04-87)

CF34 Siete mil maestros para zonas de rehabilitación (08-06-87)

CF35 Otras 50 plazas de maestros para Boyacá (13-06-87)

CF36 Piden reintegro de 300 maestros (07-07-87)

CF37 En Sumapaz. Sin maestros, sin veterinario... y sin tractor (14-07-87)

CF38 Nazareth pide que le devuelvan médico, maestros y policía (21-07-87)

CF39 Financian deuda del magisterio (22-10-87)

CF40 Plan trienal de educación. 11.800 maestros de la ciudad para el campo (02-02-88)

CF41 Nombrados ayer 376 maestros (17-02-88)

CF42 Sin maestros (21-03-88)

CF43 Radiografía de las escuelas en el país. Pocas escuelas, maestros; muchos desertores (04-05-88)

CF44 A pesar de múltiples solicitudes, una escuela a la espera de profesor (10-05-88)

CF45 Mil maestros (26-08-88)

CF46 3000 nuevos maestros (20-01-89)

CF47 Déficit docente (11-02-89)

CF48 60.000 aspirantes para 750 cargos de maestros (22-02-89)

CF49 Faltan profesores (29-03-89)

CF50 Aun faltan maestros en algunos colegios y escuelas del D. E. (30-03-89)

CF51 En el Valle hay falta de maestros (11-09-89)

CF52 Piden 700 maestros en Cundinamarca (06-10-89)

CF53 Necesitan profesores (11-10-89)

CF54 Zona rural, la más afectada: alto déficit de maestros en Valle (14-11-90) 
CF55 El MEN pedirá 15.000 plazas más para maestros (28/12/90)

CF56 Comienza censo de maestros (21/02/91)

CF57 Aclaran dudas sobre el censo de maestros (18/03/91)

CF58 Piden maestros y atención (11/05/91)

CF59 Déficit en magisterio (05/07/91)

CF60 Sin maestros $(12 / 08 / 91)$

CF61 Nuevas plazas (11/09/91)

CF62 Nombrarán 200 maestros más (26/09/91)

CF63 Por fin se sabe cuántos maestros tiene Colombia (03/10/91)

CF64 Boyacá inició clases con déficit de maestros (04/02/92)

CF65 Déficit de profesores (15/02/92)

CF66 Faltan profesores (18/02/92)

CF67 Alumnos sin maestros (29/02/92)

CF68 Cien maestros temporales trabajan en tres puestos (12/03/92)

CF69 Gobierno estudia situación de 1.600 maestros en el aire $(23 / 05 / 92)$

CF70 Cerca de 15 mil profesores jubilados por la nación (20/06/92)

CF71 Se descongelarán plazas de maestros: Mineducación (18/08/92)

CF72 Sobraban maestros (21/08/92)

CF73 Más maestros (06/10/92)

CF74 Menos del 10 por ciento de los maestros (09/11/92)

CF75 Se necesitan maestros (15/01/93)

CF76 Manizales pide educadores (08/02/93)

CF77 Nombrados los maestros adicionales (04/03/91)

CF78 Plazas para maestros (05/03/93)

CF79 Concurso docente (06/07/93)

CF80 Se buscan maestros (16/04/93)

CF81 Solicitan profesores (05/05/93)

CF82 Amplían plazo para concurso de maestros (09/12/93)

CF83 Déficit de educadores (23/02/94)

CF84 Arauca: 45.000 estudiantes sin clases (17/03/94)

CF85 Nombran 300 docentes (08/04/94)

CF86 Indígenas sin maestros (09/04/94) 
CF87 Exigen profesores (13/04/94)

CF88 Nombraran 700 nuevos maestros (20/04/94)

CF89 Piden nombrar maestros (27/04/94)

CF90 Chía no ha nombrado maestros (04/05/94)

CF91 Nombran 700 nuevos maestros (04/05/94)

CF92 Piden profesor (13/05/94)

CF93 Piden 140 maestros para Páez (25/07/94)

CF94 Exigen maestros (05/08/94)

CF95 Nombran maestros (30/08/94)

CF96 Sin maestros en Cajicá (8/10/94)

CF97 Pocos profesores, muchos alumnos (13/02/95)

CF98 Emergencia educativa por falta de maestros (23/03/95)

CF99 Usme pide maestros (31/03/95)

CF100 Distrito tendrá 600 maestros más (19/05/95)

CF101 Lista contratación de 600 maestros (15/05/95)

CF102 Estudiantes piden maestros (14/06/95)

CF103 En educación, sí hay cupo para 372 maestros elegibles $(14 / 06 / 95)$

CF104 Tres vacantes para maestros en Vaupés (08/08/95)

CF105 No más contratos por un año a los maestros (31/10/95)

CF106 No a traslado de profesores de Bogotá a Cundinamarca (29/11/95)

CF107 Nombran maestros (20/12/96)

CF108 Concurso para nombrar maestros (09/08/97)

CF109 Hoy y mañana, formularios para nombrar maestros (20/08/97)

CF110 Trasladarán a 12 maestros (15/09/98)

CF111 No habrá estudiantes sin maestros, dice SED (06/04/99)

CF112 Cuál es la pelea por los traslados (20/04/99)

CF113 Por edad, les Ilegó la hora a 150 mil maestros (10/09/2001)

CF114 Se buscan profesores (05/10/2001)

CF115 Déficit de profesores en el mundo (18/10/2001)

CF116 El Silveria, sin profesores (27/02/2002)

CF117 Santandercito, sin profesores (25/08/2003) 
CF118 Consejo de estado avala concurso de maestros (24/09/2004)

CF119 Bienvenido el concurso docente (31/10/2004)

CF120 Profesores de etnias, a concurso (11/11/2004)

CF121 Dudas sobre concurso de docentes (25/11/2004)

CF122 Aplazan examen para 60 mil cupos de profesores (03/12/2004)

CF123 Estudian alternativas para concurso docente (14/12/2004)

CF124 40 mil profesionales aspiran a ser maestros de colegio $(23 / 12 / 2004)$

\section{Actores oficiales (AO)}

$\mathrm{AO} 1$

$\mathrm{AO} 2$

$\mathrm{AO} 3$

$\mathrm{AO} 4$

$\mathrm{AO} 5$

AO6

AO7

AO8

AO9

AO10

AO11

AO12

AO13

AO14

AO15

AO16

$\mathrm{AO} 17$

AO18

AO19

AO20

$\mathrm{AO} 21$
900 mil textos escolares reparte el Mineducación (27-01-77)

Durán Dussán y su balance, 'Me voy satisfecho' (31)

Criterios liberales. Cinco ministros de educación (20-02-77)

Diálogo con educadores establece Rivas Posada (04-03-77)

Diálogo con educadores establece Rivas Posada (14-03-77)

Diálogo con educadores reanudará Rivas Posada (21-03-77)

Rivas Posada se reunirá hoy con los licenciados (12-04-77)

Diálogo y pago de reajustes anuncia el Mineducación (15-04-77)

Preparan nuevo Sistema Nacional de Educación (25-04-77)

Hoy, día del educador. Mensaje del ministro Rivas Posada (15-05-77)

Habla Rivas Posada: «La tarea: educar a los maestros» (19-06-77)

Mineducación instala seminario (21-06-77)

El gobierno no se deja intimidar: Rivas Posada (05-07-77)

Gobierno dice que no hay motivo para huelga (22-08-77)

El gobierno invita a los maestros (26-08-77)

Sigue diálogo con FECODE dice Mineducación (13-09-77)

Ultimátum a educadores (01-10-77)

Ministro de educación refuta a los maestros (06-10-77)

Habla Rivas Posada: «La tarea: educar a los maestros» (19-10-77)

Gobierno apoya reajuste salarial del magisterio (12-02-78)

Turbay y los gobernadores. Magisterio, el tema central de la reunión (20-08-78) 
AO22 Dice secretaria de educación: «La escuela debe ser el motor de la comunidad»(31-08-78)

AO23 El gobierno niega permiso para desfile de maestros (23-09-78)

AO24 Programa educativo del 79 revela el gobierno (26-12-78)

AO25 Secretaria de educación: «Los maestros 'envenenan' a los niños» (19-06-79)

AO26 No desfigurar la enseñanza, pide Turbay (27-08-79)

AO27 Dice el Mineducación: 'Están vigentes todas las garantías del magisterio' (14-12-79)

AO28 Jamás se ha suspendido carrera docente, dice el Consejo de Estado (s. f.)

AO29 No se justifica el paro de maestros, Mineducación (24-03-80)

AO30 Contacto directo con los maestros establece Secretaria de Educación (06-06-80)

AO31 Lealtad pide al magisterio Mineducación (27-07-80)

AO32 Gobierno facilita ingreso de magisterio a escalafón (29-08-80)

AO33 Dice secretaria de educación: 'Hay profesores que envenenan la mente de los niños' (28-03-81)

AO34 Mineducación asegura dineros para maestros (06-06-81)

AO35 Responsabilidad en educación pide ministro a profesores (18-09-81)

AO36 Secretaría de educación. Urge diálogo de maestros y padres (19-10-81)

AO37 En Cundinamarca. Invitación a dialogar hace el gobernador al magisterio (10-11-81)

AO38 En Cundinamarca. Secretario de educación critica descortesía del magisterio (15-11-81)

AO39 El Mineducación y estudiantes piden a maestros no hacer paro (03-03-83)

AO40 El paro de maestros es absurdo e injusto, dice Mineducación (05-05-83)

AO41 Respuesta del Gobierno a peticiones de FeCODE (02-07-83)

AO42 Mineducación se reunirá con el magisterio (04-10-83) 
AO43 Dice Mineducación: «Los maestros no pueden participar en política»; Tribunal decide situación (17-01-84)

AO44 Politización: estamos en sus manos señores maestros (26-02-84)

AO45 'El paro de maestros en un chantaje': Mineducación (20-04-85)

AO46 En Bolívar. Mineducación pide a maestros en paro someterse a la ley (29-06-85)

AO47 Mensaje de Mineducación en el día del maestro (15-05-86)

AO48 Nueva ministra pide a maestros ayuda (11-08-86)

AO49 Fondo de prestaciones para los maestros anuncia

Mineducación (14-06-87)

AO50 Mineducación garantiza pago de prestaciones a los maestros (22-12-87)

AO51 Aclara Mineducación: «Maestros de la ciudad no serán trasladados» (05-02-88)

AO52 Gobierno pide dictar clases (26-09-90)

AO53 Alcaldes nombrarán a maestros trasladados (09/08/91)

AO54 Mineducación apoya a Mockus (05/05/93)

AO55 Diálogo, pero sin presiones: Mineducación (21/05/93)

AO56 No he planteado traslado de maestros, dice secretaria (03/10/94)

AO57 Mineducación invita a levantar el paro (25-05-95)

AO58 Concejales preocupados por los profesores (15/06/95)

AO59 Sarabia insiste en diálogo con docentes (08-07-95)

AO60 Secretaría responde a peticiones de ADE (25/08/97)

AO61 Gobierno se endurece con el paro de maestros (19/10/99)

AO62 Llamado de Uribe a maestros (14/09/03)

\section{Los gremios de educadores $(G)$}
G1
El Magisterio no ha decretado huelga: FeCODE (25-01-77)
G2
FECODE presenta nuevas peticiones (24-04-77)
G3
Se retiran de ASPU 50 profesores (10-02-77)
G4
Por la orden de paro, divididos los maestros (10-5-77)
G5
Nueva entrevista solicita FECODE 23-05-77
G6
FECODE fijará en agosto fecha para paro educativo (08-07-77) 
G7 FeCODE acusa a viceministro de educación (10-09-77)

G8

G9

G10

G11

G12

G13

G14

G15

G16

G17

G18

G19

G20

G21

G22

G23

G24

G25

G26

G27

G28

G29

G30

G31

G32

G33

G34 División en el magisterio por paro nacional de hoy (08-05-84)

Sigue diálogo con FECODE dice Mineducación (13-09-77)

FECODE informa (04-10-77)

FECODE ataca a la UTC y a la CSTC (26-10-78)

FECODE se desafilia de CSTC (30-10-78)

Proselitismo político del magisterio censura Turbay (26-11-78)

La Asociación Distrital de educadores ADE... (15-06-79)

Sindicato de maestros condena fiesta patria (20-07-79)

Dice la ADE: «La Secretaría de Educación busca reprimir al magisterio»(09-12-79)

En el magisterio (11-04-80)

Movimiento del magisterio se enfrenta a grupo de ADE (26-05-80)

Hoy no habrá clase en colegios distritales por elección de junta de ADE (27-05-80)

Más de 7000 maestros en elección de la ADE (28-05-80)

La ADE. El magisterio votó en masa (29-05-80)

Sindicato de maestros ataca a la Secretaría de Educación

(21-03-81)

ASPU con el paro del magisterio (05-04-81)

En firme suspensión de FECODE por paro cívico (11-11-81)

FECODE amenaza con paro nacional contra el MAS (18-02-82)

Elegida directiva de maestros (12-08-82)

FECODE presenta pliego (29-10-82)

El magisterio (14-02-83)

Estado de descontento en magisterio del D. E. (14-02-83)

Respuesta del Gobierno a peticiones de FECODE (02-07-83)

FECODE amenaza con paro (13-08-83)

El magisterio de Boyacá denuncia al sindicato por 'destinación de dineros' (18-08-83)

Dividido magisterio del Valle (16-11-83)

Vistazo a Colombia. Magisterio participará en elecciones (30-11-83) 
G35 Parálisis total en educación, FECODE busca arreglo (12-05-84)

G36 MOIR se opone a unión FECODE COn M-19, FARC Y EPL (22-10-84)

G37 Asamblea de educadores (18-05-85)

G38 FECODE definirá paro indefinido del magisterio (02-04-86)

G39 En estado de alerta todo el magisterio (16-07-86)

G40 FECODE se afiliará a la CUt (01-09-86)

G41 Se inicia Congreso de FeCOde (16-10-86)

G42 Alerta de FECODE a los educadores (27-03-87)

G43 Magisterio rechaza ataques de las FARC en el Cauca (23-04-87)

G44 FECODE amenaza con paro (10-10-87)

G45 FECODE denuncia amenazas de muertes contra los maestros (05-11-87)

G46 Magisterio (30-01-88)

G47 Renunció presidente de FECODE (24-08-88)

G48 A punto de naufragar fondo de magisterio (01-12-88)

G49 Denuncia de FeCODE (18-03-89)

G50 Sin acuerdo la reunión entre el gobierno y FECODE (17-04-89)

G51 Magisterio sucreño, unas de cal y otras de arena (02-06-89)

G52 La descentralización. Magisterio: a los alcaldes (06-09-89)

G53 Gracias, FeCODE (14-09-89)

G54 Gracias FeCODE (17-09-89)

G55 De FECODE (23-09-89)

G56 En crisis, el magisterio (27/01/92)

G57 FECODE convoca hoy a paro de maestros (30-05-91)

G58 UTP asamblea permanente (10/06/92)

G59 Magisterio de Sumapaz responde (18/08/92)

G60 El fondo prestacional del magisterio (06/10/92)

FECODE pide modificar ley de educación (15/01/93)

G62 FECODE (24/07/93)

G63 Debate entre FECODE y Mineducación (03/10/94)

G64 En alerta el magisterio (06/10/94)

G65 FECODE pone cifras a sus peticiones (18-10-94)

G66 Se reanudaría el diálogo con FECODE (08/02/95) 
G67 FECODE tiene razón (10/02/95)

G68 FeCODE levanta paro, clases el próximo lunes (10/02/95)

G69 La educación vs. FeCODE (08/05/95)

G70 FECODE afirma que el gobierno sí tiene plata (08/05/95)

G71 Rechazo del gobierno a FeCODE (18/05/95)

G72 ADE va a proponer que se levante paro (18/05/95)

G73 Magisterio deficiente (19/04/95)

G74 FECODE no hará paro el martes y miércoles (22-04-96)

G75 Hoy sí hay clase, informó la ADE (23/04/96)

G76 FECODE, a paro (13-09-96)

G77 Firmado acuerdo entre gobierno y FECODE (18/02/97)

G78 Rechazan el acuerdo laboral de FECODE (20/02/97)

G79 FECODE amenaza con paro (05-09-98)

G80 Hierve FECODE frente al capitolio (05/05/99)

G81 FECODE dice no (28/02/02)

G82 Nace federación de educadores (06-07-03)

G83 FeCODE, el 'gallo tapao' (05/10/03)

G84 Si dan bolillo uno se sale del cuero: FeCODE (18/01/05)

G85 El magisterio no ha decretado huelga: FECODE (25-01-77) 


\section{CONTRADISCURSO Y HEGEMONÍA EN LAS REPRESENTACIONES DEL MAESTRO EN COLOMBIA}

\section{Sobre el concepto de contradiscurso}

Podría afirmarse, en principio, que un contradiscurso es un discurso que se opone, desde alguna perspectiva, a la tradición hegemónica discursiva, es decir, a aquellas lógicas de aceptabilidad, inteligibilidad, y legitimidad con las que, desde los grandes conjuntos o campos discursivos, se construyen objetos, se instituyen sujetos (Angenot, 1998) y se definen, en últimas, relaciones de poder. El contradiscurso aparece, entonces, como discurso de oposición y resistencia desde el que se pretenden alternativas de resignificación-sustitución de las representaciones-construcciones de un discurso hegemónico o dominante.

No obstante su simplicidad, esta primera definición no está exenta de dificultades, pues en el contradiscurso lo que en apariencia es resistencia u oposición, reproduce con frecuencia el «implacable monopolio de la representación hegemónica (...) donde lo totalmente divergente sería recuperado, neutralizado, traído a contribuir a la reproducción indefinida de los poderes simbólicos» (Angenot, 1989) ${ }^{1}$.

Desde esta consideración propuesta por Angenot, quien desarrolla la teoría de Bajtin sobre discurso social, el contradiscurso no puede reducirse entonces a esa concepción binaria en la que se limita a ser una simple contraposición a un discurso hegemónico dado, sino también, y sobre todo, una manifestación de la fuerza de atracción del discurso social hegemónico que se infiltra con demasiada frecuencia en las pretensiones contestatarias o de resistencia del contradiscurso.

Con estas consideraciones previas, es importante abordar la conceptualización del contradiscurso como una dimensión problemática que no se agota en la alternativa de resignificación-sustitución del discurso hegemónico; por el contrario, puede actuar como mecanismo de control-poder. En palabras de Angenot, la hegemonía posee un poder de aglomeración, una fuerza de gravedad enorme que produce en su periferia un estallido grupuscular, un fraccionamiento fatal; la hegemonía favorece el fraccionamiento de las periferias y este fraccionamiento múltiple todavía responde a su mis-

1 Texto original en francés. 
ma lógica. Desde esta perspectiva, ciertas formas de contradiscurso serían subsidiarias del discurso hegemónico, cuyo análisis, en el caso que nos ocupa, puede revestir una particular importancia, toda vez que, tratándose de los discursos del magisterio como formas de contradiscurso y/o discursos de resistencia, no estarían exentos de estos riesgos de reproducción indefinida del poder hegemónico.

Las dos concepciones tienen, no obstante, trayectoria en la teoría crítica de la sociedad y aparecen indefectiblemente ligadas al concepto de hegemonía, acuñado en la tradición marxista y desarrollado por Gramsci en sus clásicos Cuadernos de la cárcel².

Las diferencias entre una y otra forma de entender el contradiscurso quizá haya que rastrearlas en la tradición marxista, la primera; y en los estudios del discurso, la segunda. Una, en la teoría de la resistencia o contrahegemonía (Gramsci, Giroux, Freire) y otra en la filosofía del poder (Foucault) y en la teoría sociocrítica (Bourdieu, Angenot). La primera preocupada por desentrañar las formas de funcionamiento del poder en la cultura y las maneras de romper la subalternidad (hegemonía/contrahegemonía) y la segunda, centrada en el análisis del poder en los objetos discursivos, en el estudio de las problemáticas de la enunciación (Bajtin, 1992), en las reglas de funcionamiento discursivo desde las que se evidencia que:

(...) todo signo es ideológico; pero también que el discurso social no es -aunque lo pretenda- un bloque unitario o cerrado, su propia dinámica permite la existencia de zonas difusas donde se erigen valores o ideas contestatarias, (...) innovaciones, cambios discursivos que pueden erigirse en «contradiscursos». (Barei).

Como puede advertirse, ambas maneras de entender el contradiscurso tienen su anclaje en la problemática del poder y en la hegemonía como categoría primaria. Las diferencias, entonces, se derivan de los cuestionamientos que se hacen desde la perspectiva socio crítica y desde ciertas posturas posmodernas sobre la forma como dichos discursos pueden constituirse en verdaderas rupturas que se escapan de la lógica de la hegemonía o, por el contrario, son innovaciones formales que se quedan en el marco de las combinaciones permitidas por el discurso hegemónico: si operan como instrumento de socialización paralelo a otros mecanismos intransigentes o dan cuenta de un intento de atropello al uso de estos códigos. Es decir, si en algunas expresiones pueden constituir espacios de resistencia a

2 Los Cuadernos de la cárcel es el nombre con el que se conocen las notas de Gramsci durante sus años de prisión (1929-1935) en los que trata temas como la relación entre cultura y pueblo, el proceso de formación del Estado, la historia y el papel de los intelectuales, entre otras materias. 
las regularidades hegemónicas, y en otras, reproducción y afianzamiento de las mismas.

Estas posibilidades del discurso de resistencia son analizadas por Angenot como rupturas dóxicas y/o epistémicas, y propone llamar heteronomía a esa problemática en la que el discurso social escapa de la lógica hegemónica. Las rupturas dóxicas son movimientos ostentatorios y superficiales que contribuyen a la misma ideología que pretenden resistir, procediendo mediante la reactivación de ciertas estructuras discursivas que en apariencia acusan las posturas dominantes sin ir más allá, con lo que logran un efecto de sedimentación y naturalización del discurso hegemónico. Por el contrario, las rupturas epistémicas constituirían rupturas críticas que emergen en el discurso heterónomo como verdaderas disidencias. En ello estriba, entonces, la valoración positiva y/o negativa del contradiscurso.

La naturaleza del discurso hegemónico hace posible una y otra valoración del contradiscurso, pues la hegemonía establece su campo de temáticas y de cogniciones dominantes imponiendo «ideas de moda» y parámetros genéricos, (Angenot, 1989) que hacen que aún las búsquedas de originalidad y de paradoja del discurso disidente se inscriban en referencia a los elementos dominantes. En otras palabras el contradiscurso emerge de los temas y tópicas hegemónicas, pero su valoración como doxa o episteme, guarda estrecha relación con las pretensiones ideológicas de quien lo usa. El análisis del contradiscurso supone, en consecuencia, la identificación de las cargas ideológicas y su pragmática. El contradiscurso no es, por tanto, un discurso exclusivo de la resistencia de los grupos subalternos, sino también -y sobre todo- un recurso de la hegemonía para reproducirse. En este sentido no es ni ingenuo ni directo, sino oblicuo y tamizado, y por esta razón la función del analista del discurso es advertir sobre su doble naturaleza y sus posibilidades, ya de construcción normalizadora o de verdadera resistencia; de discurso «otro», surgido en la periferia del discurso dominante pero no por ello dominado.

\section{El maestro: un discurso de otros discursos}

Las representaciones sobre el maestro aparecen en el plano discursivo como discursos subsidiarios de otros más amplios (pedagogía, educación, política, etc.) que los contienen y que, en la necesidad de legitimarse, legitiman de paso la figura del maestro en función de su propio objeto discursivo. No existe, en consecuencia, una imagen del maestro que no se corresponda, de alguna manera, con las elaboraciones discursivas construidas, por ejemplo, en la teoría pedagógica, la sociología y/o la psicología 
educativas. Y aunque en la perspectiva cronológica la figura del maestro sea muy anterior a estas discursividades, su anclaje en las representaciones sociales se produce por efectos de la cristalización de esos discursos en el universo social. En efecto, como señala Serna:

(...) las luchas históricas en torno a la definición legítima del universo de la pedagogía han puesto en medio, al mismo tiempo, la definición legítima del maestro, un trabajo dirigido a universalizar su presencia (haciéndola extensiva para todo el mundo social) (...). De allí que la legitimación del maestro haya quedado aprehendida históricamente a la multiplicidad de instancias que se consideran tutoras legítimas de la universalidad admitida (en su momento, por ejemplo, la Iglesia), siendo las más recientes las burocracias del Estado y los colectivos académicos, científicos e intelectuales (2004, p. 95).

Ahora bien, esa universalidad admitida de la presencia del maestro no se reduce a la legitimación de su existencia, sino que conlleva también imágenes sobre las condiciones históricas de su origen social y de las prácticas educativas; sobre la naturaleza de su oficio y su ubicación jerárquica en el saber, el poder y en el rol que se le asigna como actor social. Estas son las imágenes construidas en los discursos secundarios de las ciencias y demás instancias de legitimación discursiva (Gee, 2005), las cuáles se proyectan en las prácticas discursivas y las retóricas de la educación (cf. Ratinoff, 1994), el periodismo, la política, y aún en el discurso gremial sobre los maestros.

Esta investigación partió, entonces, de la identificación preliminar de las representaciones sobre el maestro surgidas en el interior de campos discursivos como la pedagogía, la historia y la sociología educativas, e intenta mostrar cómo dichas representaciones se cristalizan y se usan de manera retórica en los discursos de la prensa escrita, la política educativa y aún en el contradiscurso del gremio «como argumentos públicos (...) para aglutinar voluntades y para proporcionar conceptos de orden que faciliten organizar factores» (Ratinoff, 1994, p. 23).

\subsection{De apóstol a funcionario}

Una de las primeras imágenes del maestro, y quizá de las de mayor permanencia en el tiempo, es la del apóstol o catequista. Estrechamente ligada al rol de la iglesia católica -que en el caso colombiano fue, durante mucho tiempo, el único credo religioso y la institución a la cual se le confió la tarea educadora-, definió un ideal de maestro más cercano al papel del sacerdote o del apóstol en su función moralizadora y evangelizadora, que a la de profesional de la enseñanza. Una gran variedad de estudios analizan 
esta representación del oficio, desde las perspectivas histórica y sociológica, determinando el impacto de dicha imagen social, tanto en el plano de las condiciones éticas y morales imaginadas sobre los individuos dedicados a la enseñanza y sus proyecciones en la niñez y la juventud, como en las consideraciones socioeconómicas y políticas del oficio:

La enseñanza, más que una profesión, es una «misión» a la que uno se entrega, lo cual supone una gratuidad proclamada que no se condice con lo que la sociedad espera de una profesión, entendida como actividad de la cual se vive, es decir, de la que se obtiene un ingreso y una serie de ventajas instrumentales (salario, prestigio, etc.). (Tedesco, Tenti, 2002, p. 71).

Asociados a esta imagen fundacional del maestro, emergen una serie de imperativos morales, de virtud y de acciones de los maestros que suponen

(...) entender su labor como destino, pues está trazado el camino y no hay lugar a desviaciones (...). Y mostrarse siempre y en todo lugar como un ser pudoroso y leal, benévolo, afable y abnegado, que (...) no accederá a tabernas ni casas de juego, y no podrá sin el permiso de la inspección local aumentar sus medios de subsistencia con el ejercicio de funciones accesorias (Álvarez, 2007).

Esto, sin duda, configura una imagen de maestro desdibujada por el peso de la carga moral, el sacrificio, la tolerancia, la paciencia y la entrega altruista a los demás; aunque sus posibilidades de existencia dependan, literalmente, de la caridad pública.

El reconocimiento por parte de quienes así conciben su labor como ardua y difícil, a la cual no pueden acceder sino aquellos hombres y mujeres de espíritus más sacrificados y virtudes más excelsas, parece ser el dispositivo retórico para el sometimiento a las particulares condiciones de siervo que se le imponen, pues esas virtudes morales y de servicio que se le atribuyen son también los dispositivos de control y vigilancia que asumen quienes actúan como sensores de su ministerio: el párroco, las élites y la burocracia de Estado. El maestro-apóstol es, en consecuencia, un sujeto vigilado, supervisado y escindido de los beneficios materiales de cualquier otra profesión:

Fijemos nuestra mirada escrutadora y justa en la conducta, vida pública o privada de los maestros; excluyamos los malos como frutas dañadas del cesto (...) Ilamemos los buenos a ejercer el santo magisterio, sostengámoslos en su labor civilizadora (en Álvarez, Óp. Cit.).

No solo por lo que hace, sino también por cómo lo hace, la supervisión y el control se constituyen en los otros componentes de la emergencia social 
del maestro, pues establecidas las condiciones de orden moral y de virtud, es necesario establecer las del oficio: la enseñanza. Y para ello se requiere tanto la existencia del método y del tipo de saberes que debe acopiar un maestro, como la de los censores de los mismos: alcaldes, curas y supervisores, con lo cual se establece, de paso, la naturaleza de ese oficio y las relaciones del maestro con el poder ${ }^{3}$.

Ante el resquebrajamiento de las lógicas discursivas sobre el maestroapóstol, imposibles de sostener en una sociedad que avanza progresivamente en el orden capitalista, en la industrialización y la secularización de la vida, surge progresivamente la figura del maestro funcionario. Su subsistencia física no depende ya de la caridad pública, sino del ordenamiento jurídico:

Cuando hacia la segunda mitad del siglo xvIII el Estado declara la educación como objeto público, la enseñanza de las primeras letras pasa a ser un oficio civil (...) hacia el cual confluyen alguno sujetos con la pretensión de mantener una posición con asomos de decoro (Martínez Boom, Castro, Noguera, 1989, p. 114).

Esta incursión del maestro como funcionario provoca la reacción inmediata de curas y burócratas, quienes lo acusan de mercader de la enseñanza, mendigo de un salario, individuo desheredado sin ninguna raigambre social, y explica la necesidad de ejercer el control y la vigilancia en torno a esa nueva figura cuya legitimación a través de la estrategia de instrucción pública 4 provoca reacciones originadas en las luchas de poder entre Iglesia y Estado, entre poder moral y poder político.

Es el momento en que se hacen visibles las tensiones entre dos lógicas fundacionales de la imagen del maestro: la de la vocación y el apostolado, vs. el oficio aprendido. En este debate ideológico y político la figura del maestro queda atrapada, se convierte en rehén de los intereses de una u otra lógica:

El peso que tienen las representaciones relacionadas con la vocación y las cualidades morales del docente se explica por la función que se asigna al sistema educativo en el momento constitutivo del Estado y la sociedad capitalista moderna (Tedesco y Tenti, 2002).

3 Al respecto pueden consultarse los trabajos de Sáenz, Saldarriaga, Ospina, 1997; Saldarriaga, 2000, 2003, 2006; Helg, 1987; Zuloaga, 1984, 1987; Castro y Noguera, 1997; Calonje y Quiceno, 1984; Quiceno, 2003, 2004; Calonje, 1986; Martínez, Castro, Noguera, 1989; Cataño, 1989; Parra Sandoval, 1980, 1986, 1996; Herrera y Low, 1994.

4 En el siglo xIx se denomina instrucción pública a toda actividad de enseñanza organizada y vigilada por el Estado, entendido este como un Estado docente que definía en lo dogmático y en lo científico, lo bueno y lo malo, lo falso y lo verdadero (...) Dicha reglamentación y vigilancia implicaba que el estado docente se reservaba para sí toda la libertad de estudios, fijando el método, las instituciones y los objetos de enseñanza (Zuloaga, 1999, p. 123). 
En otras palabras, es el enfrentamiento entre la lógica del poder moral (Zuloaga, 1999) que reclama como condiciones fundamentales del maestro la gratuidad de su oficio, la entrega sacrificada a los demás, la instrucción en la fe y moral cristianas, la virtud y la paciencia; y la lógica del oficio aprendido, que postula el dominio de conocimientos y técnicas para la enseñanza (didáctica) de las habilidades básicas de lectura, escritura, cálculo, moral, higiene, policía, etc. Es el momento también en que se desvelan las "urgencias Iloradas» de los aspirantes al nombramiento y de quienes, habiéndolo obtenido, mendigan ahora -ante las autoridades- el reconocimiento y la paga de un salario por los servicios prestados y son rehénes de la lucha entre poderes.

Sin embargo estas lógicas no son excluyentes; una y otra se cruzan y entrecruzan de manera constante cuando los intereses de cada poder lo justifican. En efecto, muchas de las premisas de la estrategia moral no se desechan sino que se incorporan a las de la estrategia de instrucción:

La ciencia racional y la escuela eran el equivalente funcional de la religión y la iglesia en las sociedades occidentales precapitalistas. La ideología positivista que presidió el proceso de secularización que acompañó la conformación de los sistemas educativos reivindicó para la ciencia y la escuela un carácter y una dignidad moral casi sagrados. La escuela del Estado tenía por función construir esa nueva subjetividad que se le asignaba al ciudadano de la república moderna. La tarea del maestro era el resultado de una vocación, su tarea se asimila a un "sacerdocio» o "apostolado» y la escuela es "el templo del saber» (Tedesco y Tenti, Óp. Cit., p. 70).

Ese refuerzo mutuo entre lógicas discursivas hizo la figura del maestro, cuya emergencia en el espacio social hizo también el discurso que lo ancló en el plano de las representaciones sociales. Así emerge una idea de funcionario encargado del disciplinamiento del cuerpo y la mente, el cual es, a su vez, disciplinado, vigilado y supervisado. La estructura de la estrategia de instrucción pública que asegura la emergencia del maestro como actor social, determina también la naturaleza y el estatus de su labor: apóstol, pero técnico; vigilante, pero vigilado; buen súbdito, pero desarraigado; precariamente incluido en la cultura letrada y sin embargo con la función de educar a los otros, de formar los cuerpos y las mentes de las nuevas generaciones. El resultado es, cuando no contradictorio, difícil de admitir en el escenario de las circunstancias históricas y sociopolíticas en que emerge su figura.

En ese entrecruce del discurso fundacional, inestable y contradictorio, se tejió entonces esa visión particular -tal vez ingenua pero peligrosa- del oficio de enseñar y de su protagonista: el maestro, que quizá sirva como 
dispositivo histórico y sociológico para comprender las lógicas discursivas contemporáneas con las que se lo representa.

\subsection{Entre el artesano y el técnico}

Frente a las anteriores imágenes fundacionales del maestro, de las cuales podría afirmarse que constituyen representaciones acuñadas por el discurso histórico-sociológico, surgen nuevas representaciones originadas en lo que De Tezanos (1985) denominó «las maneras de dictar clase», en las que se reubica al maestro en relación con su proceso formativo y particularmente en el papel de las escuelas normales. Esta mirada, de corte pedagógico, se establece a partir de la confrontación entre lo que registran los documentos oficiales (programas y manuales), que pueden considerarse prescripciones sobre el oficio, y la realidad del proceso formativo en las aulas (lo real de lo teórico). Mediante la oposición entre lo vocacional, lo práctico y lo teórico en la formación de los maestros, la autora rescata la naturaleza de un oficio determinado, en su dimensión pedagógica, por «el método de enseñanza». La nueva representación se descentra de la mirada sociológica e histórica del sujeto que encarna el oficio y se detiene en el estudio de los dispositivos de su formación (los métodos) y en los aconteceres de la realidad en las aulas:

A partir de esta interpretación -dice la autora- surge una nueva propuesta de transformación, que intenta aportar a una discusión que tienda a resolver la contradicción que se plantea en la comprensión de la imagen y papel del maestro como un artesano o un intelectual (De Tezanos, 1985, p. 22).

La imagen del maestro artesano se vincula estrechamente con sus procesos formativos por el modo en que aprende y ejerce el oficio -basada en el principio de imitación- a la manera de los artesanos que deben:

(...) aprender su arte, como en las antiguas corporaciones medievales, por procesos de transmisión verbal, demostración e imitación de un conjunto de acciones y estrategias que se consideran necesarias para ejercer el oficio de enseñar. Por tanto, el maestro debe hacerse a imagen y semejanza de otro maestro, quien le dirá qué hacer y cómo hacerlo (Ibíd., p. 80).

Sin embargo, formar al maestro a «imagen y semejanza» no se reduce al proceso de imitación, sino que se instrumentaliza de manera progresiva en los manuales de formación práctica con los cuales se pretende, desde lo prescriptivo, alcanzar ciertos grados de organización que aseguren el 
dominio de técnicas adecuadas para el oficio de enseñar. El maestro aprendiz imita las maneras de hacer de su tutor, quien a su vez se guía por los manuales que le prescriben las técnicas y procedimientos para el trabajo en el aula. El resultado, bien sabido, es que el peso de lo práctico, derivado de la experiencia aprendida con el maestro mentor, determina un modo de pensar(se) del maestro a la manera del artesano «que aprende su oficio, corporativamente, con otro maestro como modelo» (Ibíd.).

La ubicación del maestro como técnico y/o artesano conlleva, como en el caso de las imágenes fundacionales, ciertas cargas ideológicas que determinan la valoración social del oficio y que, para los propósitos de esta investigación, resultan relevantes puesto que de la valoración del tipo de saber que ejerce el maestro, se determina también su estatus en la escala social de las profesiones:

Entre los sujetos que de una u otra manera se relacionan con el discurso de las ciencias o de los conocimientos, hay uno de ellos cuya forma de relación designa una opresión cultural que se establece a través del método de enseñanza: ese es el maestro (...) Mientras más inferior sea la situación cultural del maestro, le es confiado en mayor medida su oficio metodológico (Zuloaga, Óp. Cit., p. 156).

En efecto, la reducción de la práctica pedagógica del maestro al oficio metodológico instaura, o mejor, reposiciona condiciones comunes a su ejercicio técnico, que en el decir de Ballanti (1979) se sintetizan en dependencia, incompetencia, institucionalización y tradicionalismo.

Cada una de estas cuatro "condiciones» del oficio técnico-artesanal del maestro remite, de manera indefectible, a esa situación subalterna de su trabajo que depende, como en el caso de todos los artesanos, de los intereses y necesidades de las clases dirigentes. El maestro, requerido para la transmisión de la cultura letrada, no tiene sin embargo la autonomía para decidir ni los contenidos ni los métodos. De allí que esa dependencia

(...) no sea solo social sino también científica y operativa (...) Al docente casi nunca le ha sido concedida por su específica competencia la posibilidad de fijar los objetivos y las reglas de procedimiento del propio trabajo ni buscar con independencia los instrumentos aptos para ejercerlo (...) Y lo más grave es que ha visto brotar de fuentes que no eran, la exacta reflexión sobre la propia operatividad, las normas o reglas de su trabajo (Ballanti, 1979, p. 35).

En el mismo sentido, la idea de la incompetencia se deriva de las continuas exigencias que se hacen a su trabajo: fungir como apóstol, como artista-artesano, como moralista, como filósofo, psicólogo y sociólogo. Des- 
de estas exigencias fácilmente se acuña una idea de incompetencia ligada a la gran variedad de comportamientos que no se exigen para ninguna otra profesión. Por ello la necesidad de institucionalizarlo, pues en la institución (la escolar) se reglan las finalidades, los procedimientos, los contenidos, los niveles de autoridad; se resuelven los problemas acerca del qué y el cómo del oficio, de la cantidad y el tiempo que debe dedicar el maestro para alcanzar los objetivos del programa cultural y evaluativo de la escuela.

Por último, la idea del tradicionalismo se asocia con aquella tesis planteada por Not (1989) en relación con los contenidos y con los métodos de enseñanza. El maestro es tradicionalista tanto porque se adhiere a unas formas de transmisión de la cultura (determinados métodos) puestas en cuestión cuando se exigen resultados más visibles de su accionar pedagógico, como cuando aborda los contenidos desde ciertas tradiciones discursivas «añejas» o desactualizadas (en las que él se formó) en relación con las nuevas perspectivas teóricas de las disciplinas que enseña.

Lo paradójico de estas representaciones es que, en tanto que recuerdan cuál es la naturaleza de su oficio, sirven también para fabricar ciertas otras que se usan de manera retórica, cada vez que las instancias de «legitimación discursiva» requieren justificar los cambios que definen una política educativa. Si están del lado de las reformas, son autónomos y en comunidades académicas; si no lo están, son heterónomos y aislados; constructores de currículo o dictadores de clase, tradicionalistas o innovadores; competentes o incompetentes (Bustamante, 2001).

Otras imágenes del maestro, construidas también dentro del discurso sustancialmente técnico de su oficio, se derivan del reduccionismo instrumental de la psicología educativa que vino a sustituir significativamente la imagen del maestro-artesano. Dichas imágenes se originan en los programas de investigación de la enseñanza -como el programa proceso-producto (cf. Shulman, 1989)-, que redujeron la labor del profesor, y de hecho su valoración social, a una serie de conductas docentes definidas desde la psicología conductista en la que se acuñaron las imágenes de operador de refuerzos de aprendizaje, administrador de currículo, modelador de conductas, etc. Este programa, de gran impacto en las escuelas de formación de maestros, hizo que durante mucho tiempo la labor del docente y la forma como este representara su quehacer, se redujera a las conductas de control del aula o a las de instrucción genérica. Por este camino se fortaleció la imagen del técnico que activa máquinas para la enseñanza. En estas apreciaciones no hay lugar, entonces, para una representación del oficio de maestro que lo libere de la dependencia y permita que se lo represente y se re- presente a sí mismo y a su labor de manera distinta a la de operario, técnico, cuyo 
saber, sustancialmente instrumental, lo priva del ejercicio de pensar, reduce su oficio al cumplimiento de rutinas y lo sustrae de toda consideración intelectual y política de su figura.

\subsection{Asalariados e intelectuales}

Las luchas teóricas por dotar a la pedagogía del estatus de disciplina, acompañadas por los movimientos magisteriales que se dieron durante las últimas décadas del siglo xx y por los cambios radicales en los modelos de desarrollo económico, produjeron nuevas representaciones del maestro que habrían de oponerse a la figura del técnico, rescatando para este actor social una dimensión intelectual y política, en la que emerge como erudito, como trabajador de la cultura, agente de cambio social, constructor de ciudadanía, etc. Estas nuevas representaciones tienen la particularidad de haberse forjado, tanto en las perspectivas críticas de la pedagogía $-y$, por lo tanto, en las luchas discursivas gremiales y de intelectuales de izquierda-, como en los discursos oficiales que demandan nuevos retos para el ejercicio de la profesión. De allí que resulte interesante, como es el propósito de esta investigación, deslindar los campos de producción discursiva en torno a la figura del maestro y advertir cómo se producen, re-producen, y aún, se comparten imaginarios antagónicos sobre el maestro cuando las necesidades de legitimación de intereses lo requieren, tanto en las agencias de poder político como en las organizaciones gremiales que los resisten. Es este el fenómeno del que se ocupa el concepto de contradiscurso, cuando analiza las rupturas epistémicas o los deslizamientos doxicos en el discurso social sobre los maestros. Esto es, cuándo el discurso de resistencia gremial ha contribuido a la sedimentación y naturalización del discurso hegemónico y cuándo ha logrado romper el cerco discursivo que ésta le impone.

En efecto, como se verá a lo largo de este trabajo, tanto el contradiscurso (discurso de la resistencia) con el que se opone el gremio de los maestros a las políticas de gobierno y de Estado, como el discurso oficial, parecen nutrirse de las mismas condiciones históricas, aunque las necesidades retóricas y discursivas legitimen ese estatus de intelectual que le atribuyen para fines sustancialmente distintos, de acuerdo con cada coyuntura política, con cada «situación» que reclama la presencia del maestro como intelectual. De un lado, las representaciones «oficiales» que otorgan al maestro esa condición de intelectual, son esfuerzos retóricos para lograr de estos actores sociales los compromisos necesarios para acometer las nuevas demandas que se hacen a la escuela. Una educación por competencias, por ejemplo, requiere profesionales reflexivos, críticos, creativos (verdaderos intelectuales) capaces de responder a los retos de la educación en la «sociedad del conocimiento». 
De otra parte, el contradiscurso supone un maestro intelectual, reflexivo y crítico que asuma su responsabilidad política en la construcción de nación y responda con su saber pedagógico a las arremetidas del orden neoliberal que pretenden convertir las escuelas en simples escenarios de socialización y compensación de las desigualdades sociales (cf. Pérez, 1999). Estas representaciones acuñan aquella figura del intelectual basadas en lógicas que evidencian relaciones de poder y fines políticos encontrados, unas en la pedagogía crítica que se encarnó en el discurso fundacional de Freire a mediados de los años sesenta y que, en América Latina, es inseparable de los movimientos sociales característicos de estos años; otras en las más recientes demandas de los organismos internacionales que intervienen la educación para satisfacer los requerimientos del nuevo orden económico.

Ambos discursos tienen, sin embargo, una base común: la transformación reciente de las concepciones sobre los fines de la educación. El replanteamiento de estos fines que se advierte tanto en la producción discursiva oficial como en los intelectuales y el gremio de los maestros, evidencia la disyuntiva entre dos lógicas: la de distribución vs. la de producción de conocimientos. El modelo de distribución de conocimientos, dominante a lo largo de la historia de la educación, privilegia la transmisión de la herencia cultural, exalta los valores constituidos y le da estatuto de verdad a toda la tradición académica (cf. Not, 1989). El papel del maestro, de frente a esta concepción, no puede ser otro que el de técnico encargado de la administración de los currículos, el control de la clase y la evaluación de los aprendizajes en términos de conductas operadas. La responsabilidad por los saberes que imparte se limita a la ejecución de contenidos que le son señalados en planes y programas que él debe administrar de manera gradual, mientras asegura la normalización «mediante mecanismos disciplinarios de control social (concepción autoritaria) y de homogenización del saber (didácticas estandarizadas y sistemas de examen)»(Cajiao, 1997, p. 73).

Frente a esta lógica distribucional, las demandas que se hacen al maestro son técnicas, centradas en la difusión de la cultura pública y la socialización de los valores consagrados. El aprendizaje que procura en sus estudiantes, es un aprendizaje académico desprovisto de valores distintos a los de la promoción escolar, para los que no se requiere reflexión, curiosidad, ni análisis crítico (condiciones básicas del trabajo intelectual), pues los conocimientos ya están organizados y empaquetados en currículos, planes, programas y metodologías. En esta lógica, la valoración y reconocimiento social de su oficio se reduce a calificar los niveles de eficiencia y eficacia de su desempeño, en relación con la tarea que se le asigna. No se requiere un intelectual para asegurar esta función socializadora y normalizadora de la escuela. 
Por el contrario, el discurso que sustenta la producción de conocimiento supone un trabajo reflexivo y crítico de maestros y estudiantes desde el cual se logren las «competencias» de lectura, escritura, cálculo matemático, análisis y crítica del entorno social y capacidad para la recepción crítica de medios de comunicación masiva; para el trabajo en grupo, el auto aprendizaje y el auto acceso a la información, entre otros "códigos de la modernidad» (cf. D’lors, 1994) que postulan los nuevos discursos oficiales sobre la educación (y que conllevan una visión distinta del maestro como intelectual (cierto tipo de intelectual) capaz de producir sujetos transformadores que responden con creatividad y asertividad a los desafíos del mundo moderno; o desde el contradiscurso: a generar resistencias contrahegemónicas que permitan a los profesores producir los conocimientos necesarios para replantear las cuestiones referentes a la naturaleza del poder, la ideología y la cultura y cómo funcionan estos en la elaboración de ideas sobre lo social, y en la creación y justificación de fijadas formas de rutina del estudiante.

El elemento común de estas representaciones es la figura del maestro intelectual, aunque sean distintas las formas de concebirlo. En la perspectiva de los movimientos gremiales, en cuya base operan los contradiscursos o discursos de resistencia, la figura del maestro intelectual está asociada a la lucha por el ejercicio de la autonomía y la determinación de unos roles más comprometidos con la construcción de la democracia, el ejercicio del poder-saber y la función sustancialmente educativa de la escuela. En el caso colombiano, esta pretensión se encarna en el movimiento pedagógico de comienzos de los ochenta, aunque sus primeras manifestaciones se remonten al experimento liberal de los años treinta, cuando se los puso en contacto con la investigación y, como era de esperarse, se convirtieron en un problema, debiendo abandonar el país y/o vincularse a la docencia universitaria (cf. Herrera y Low, 1994).

El Movimiento Pedagógico (MP) no solo se constituyó en la plataforma pedagógico-política que legitimó la emergencia del discurso sobre el maestro intelectual, sino que, además, hizo visible un discurso contra el poder hegemónico del Estado y aún contra el dogmatismo partidista de la izquierda, que no comprendía que una organización sindical como FECODE Considerara importante el fortalecimiento pedagógico. En efecto, la premisa fundacional del MP que aparece en las conclusiones del XII Congreso de FECODE (Bucaramanga) propone:

Impulsar un movimiento pedagógico a nivel nacional que conlleve la recuperación del maestro como trabajador de la cultura y en su proyección social al interior de toda la comunidad. Por lo tanto, la lucha por una pedagogía y educación democrática debe estar articulada a la lucha sindical y política, que adelanta el magisterio por mejores rei- 
vindicaciones y por una educación al servicio del pueblo (Rodríguez y Peñuela, 2006, p.104).

El interés por lo pedagógico del MP recoge los desarrollos de la educación popular que trasciende a la escuela tradicional y ubica al maestro como un trabajador de la cultura y, por tanto, como un intelectual en términos de Gramsci (1979), comprometido con la educación como un proyecto liberador. Estas representaciones del maestro redimensionan la concepción de la pedagogía y posicionan al saber pedagógico como la categoría central y el objeto de toda la construcción discursiva en torno al docente. Distintos grupos de investigación se ocupan entonces de la construcción discursiva y de la comprensión de las prácticas pedagógicas, su historia, sus actores y realizaciones en la educación popular y en la educación formal. En esa dinámica discursiva se desarrollan los trabajos de Zuloaga (1987), Martínez y Rojas (1984), De Tezanos (1985), Herrera y Low (1994), Sáez, Saldarriaga y Ospina (1997), Díaz (1989) y de un gran número de artículos publicados en la revista Educación y Cultura que se convirtió, desde entonces, en el órgano de difusión del MP y de las luchas gremiales de FECODE. En el ámbito internacional, muchos de los trabajos de la teoría crítica de la pedagogía se inscriben también en esta línea, que concibe al maestro como un intelectual militante que se contrapone y resiste desde sus prácticas y saber pedagógico a las prácticas educativas hegemónicas 5 .

Esa figura del maestro intelectual -en el contradiscurso o discurso de la resistencia- asociada al concepto de saber pedagógico, concibe al maestro como productor de conocimiento. Supone que, desde la escritura, establece un diálogo permanente con la teoría pedagógica, los saberes disciplinares y con la noción de trabajo pedagógico como mecanismos para lograr la desalineación que le impusieron los métodos de enseñanza, la tecnologización de la educación y los demás mecanismos de control que impuso el estado docente. El maestro intelectual actúa desde la noción de trabajo pedagógico, como «uno de los modos que asume la relación entre trabajo intelectual y trabajo manual (...) una acción productiva intencional que no solo implica resultados materiales sino creación de conocimiento y saber» (De Tezanos, 2006, p. 58).

Ese saber es el pedagógico, producido por el maestro como resultado de la triple relación entre práctica, reflexión y tradición del oficio, que se hace visible en la escritura. Sin embargo esa escritura -requisito del trabajo intelectual- aparece atrapada en las condiciones institucionales: para rendir informes, para llenar documentos, para planear las clases, para adoptar los

5 Cfr. V.gr. Giroux (1990, 1997), Apple (1996, 1997), McLaren (1998) y Pérez (1998, 2002). 
currículos determinados desde las prescripciones del centro o, en el mejor de los casos, para dar cuenta de las aplicaciones didactistas de métodos y contenidos disciplinares desde los ahora nuevos «enfoques cognitivos» de la enseñanza, mientras se aplazan las preguntas sobre sí mismo y sobre las condiciones en que es producido. Preguntas y respuestas éstas que parecen el patrimonio discursivo de los otros, los depositarios de los discursos de la sociología, la psicología, la antropología, etc.

En esa lógica, todos estos esfuerzos discursivos por producir la imagen del maestro intelectual parecen, hoy más que nunca, reducidos al ejercicio retórico o, cuando menos, al ideario del deber ser de un sujeto, ahora profesional de la educación (el discurso alterno al del intelectual), atrapado en las lógicas del mercado que cooptan el discurso sobre el maestro intelectual, para su propios fines:

El maestro como intelectual hoy, en su estatuto actual, es parte estratégica de ese modo de producirse y reproducirse la realidad. Durante un tiempo se intentó reemplazarlo con la tecnología, pero ya no es posible porque en él hay una inteligencia que no producen las máquinas o el trabajo plantificado y repetitivo, que es la capacidad de inventar, de crear, de transformarse, y eso es lo que produce valor hoy y eso es necesario para el capital (Álvarez, 2006, p. 140).

Desde estos razonamientos, la pregunta por las representaciones discursivas sobre el maestro parecen, entonces, representaciones de otros y no de los propios maestros, sometidos a ser procesados por esos otros. Esto es, a pensarse a medio camino entre el artesano y el intelectual, que hereda la manera de «hacer el oficio» mientras reflexiona sobre cómo hacerlo mejor, aunque las preguntas sobre sí mismo y sobre los efectos de las prescripciones de la ciencia, la ética y la política sobre su quehacer continúen aplazándose indefinidamente.

\section{El contradiscurso en la revista Educación y cultura}

\subsection{Sobre el procedimiento metodológico}

A continuación se analiza un corpus de 87 artículos seleccionados de la revista Educación y Cultura (números 1 a 79) en los que puede identificarse el fenómeno del contradiscurso, aunque allí no se agota la producción discursiva aparecida en la revista de FECODE; su selección se hizo siguiendo la propuesta metodológica del análisis de contenido a partir de la identificación de enunciados (nivel de superficie) o identificación de referencias 
(temas) que, en mi criterio, reflejaran formas de resistencia u oposición al discurso dominante, así como el deslizamiento o naturalización de las representaciones hegemónicas. En estas temáticas que comprometen al maestro como actor social, se pueden advertir tanto formas de resistencia u oposición al discurso hegemónico como su naturalización y sedimentación en el discurso de los profesores. La topicalización posterior de estas temáticas (mediante el análisis de su desarrollo discursivo) permitió la clasificación según valoraciones positivas y/o negativas de las representaciones así construidas. Es decir, se establecieron las diferencias de rasgos en la información y se eligieron, a manera de evidencias textuales, los segmentos de los artículos que apoyaran la apuesta interpretativa.

La identificación y clasificación del corpus, considerando la agenda temática de la revista Educación y Cultura, permitió el ordenamiento de los artículos que desarrollan dicha agenda. El resultado se puede apreciar en la gráfica que se presenta a continuación.

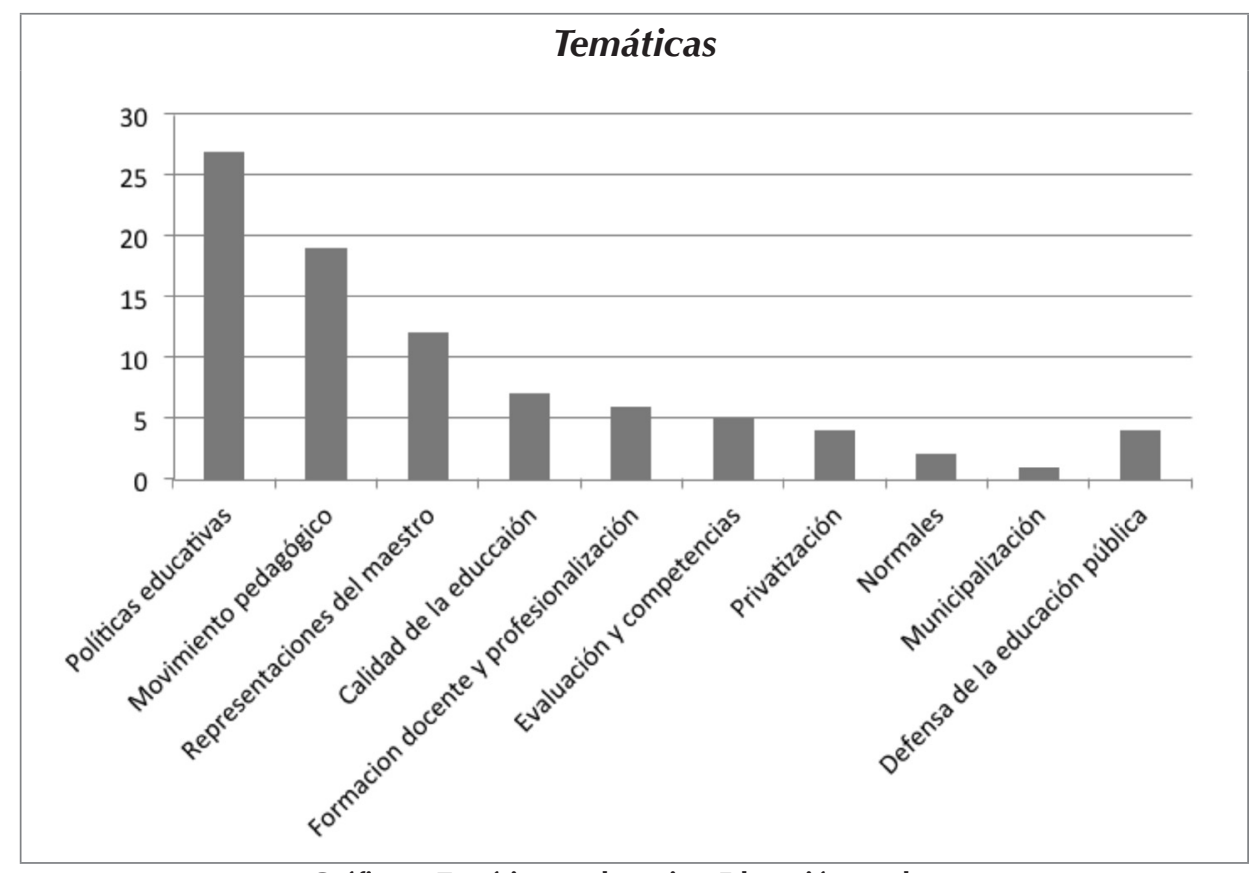

Gráfica 5. Temáticas en la revista Educación y cultura

Siguiendo un criterio metodológico de reducción de datos para facilitar el análisis, estas diez temáticas y 87 artículos se reagruparon hasta obtener tres grandes categorías de análisis del corpus. Con este procedimiento se crearon subcategorías constituyentes de cada uno de los tres grandes ejes temáticos (Tablas 1, 2 y 3) y se puso en evidencia cómo el tema de las polí- 
ticas educativas ocupa el 64\% del total de artículos estudiados de la revista Educación y Cultura, mientras los temas del Movimiento Pedagógico y las representaciones del maestro se aproximan al 22\% y al 14\%, respectivamente.

\begin{tabular}{|c|c|c|}
\hline Categoría & Subcategoría & $\begin{array}{l}\text { Total de } \\
\text { artículos }\end{array}$ \\
\hline \multirow{7}{*}{ Políticas educativas } & $\begin{array}{l}\text { Planes de desarrollo } \\
\text { Apertura educativa } \\
\text { Reformas/revolución educativa } \\
\text { Municipalización }\end{array}$ & 21 \\
\hline & $\begin{array}{l}\text { Formación docente } \\
\text { Profesionalización }\end{array}$ & 8 \\
\hline & Calidad de la educación & 6 \\
\hline & $\begin{array}{l}\text { Evaluación } \\
\text { Competencias }\end{array}$ & 10 \\
\hline & Defensa educación & 8 \\
\hline & Privatización & 3 \\
\hline & Total & 56 \\
\hline
\end{tabular}

Cuadro 3. Políticas educativas

\begin{tabular}{|l|l|c|}
\hline \multicolumn{1}{|c|}{ Categoría } & \multicolumn{1}{|c|}{ Subcategoría } & \multicolumn{1}{c|}{$\begin{array}{c}\text { Total de } \\
\text { artículos }\end{array}$} \\
\hline \multirow{3}{*}{$\begin{array}{l}\text { Movimiento } \\
\text { pedagógico }\end{array}$} & $\begin{array}{l}\text { Historia/Orígenes } \\
\text { Fundamentos/propósitos }\end{array}$ & 9 \\
\cline { 2 - 3 } & Acciones/tareas & 7 \\
\cline { 2 - 3 } & Perspectivas & 3 \\
\cline { 2 - 3 } & Total & $\mathbf{1 9}$ \\
\hline
\end{tabular}

Cuadro 4. Movimiento pedagógico

\begin{tabular}{|l|l|c|}
\hline \multicolumn{1}{|c|}{ Categoría } & \multicolumn{1}{|c|}{ Subcategoria } & $\begin{array}{c}\text { Total de } \\
\text { artículos }\end{array}$ \\
\hline \multirow{2}{*}{$\begin{array}{l}\text { Representaciones } \\
\text { del maestro }\end{array}$} & Identidad profesional & 5 \\
\cline { 2 - 3 } & Imagen Social & 7 \\
\cline { 2 - 3 } & Total & $\mathbf{1 2}$ \\
\hline
\end{tabular}

Cuadro 5. Representaciones del maestro 


\subsection{Análisis y discusión}

\section{El discurso de las políticas educativas}

Frente a los temas de política educativa, el alto porcentaje de artículos referidos constituye ya un indicador de la naturaleza sustancialmente política de los textos publicados en la revista Educación y Cultura. La tendencia de la revista a ocuparse prioritariamente de esta temática pone de relieve la importancia que para la organización gremial tiene el componente político de la educación, aún por encima de los temas de naturaleza pedagógica y didáctica y/o de representaciones del maestro como actor social.

Aunque en una perspectiva amplia todo el discurso sobre educación y pedagogía pueda relacionarse con la política, es posible establecer diferencias específicas entre algunas manifestaciones del discurso pedagógico y educativo, y aquel sector de producción discursiva que se ocupa de manera puntual de asuntos de política. Esto es, de las regulaciones macroeconómicas, de legislación y de administración de los recursos para el sector.

Esta consideración nos permite discriminar entre las políticas propiamente dichas, definidas en los planes de desarrollo, reformas y leyes que los contienen y su proyección en los procesos de formación y profesionalización docente, en la construcción de imaginarios sobre calidad educativa, evaluación, competencias y formación ciudadana, etc., en los que se cristalizan y se traducen en acciones prácticas los lineamientos de la política.

Desde esta perspectiva podemos emprender, entonces, una aproximación analítica a lo que hemos denominado «contradiscurso» en el sentido de hacer visibles la naturalización y la sedimentación de los discursos hegemónicos, sus cargas semánticas, o bien el desentrañamiento de sus lógicas, las rupturas y las apuestas «innovadoras» que lo resisten.

En el contradiscurso de los maestros, como se evidencia a lo largo de todo este apartado, las reformas a la legislación educativa (decretos 2277 y 1278 , y otros tantos que los desarrollan y/o reforman), constituyen el trasfondo de confrontación entre Estado y gremio. En el discurso gremial aparece el problema de la crisis de financiamiento de la educación y, de manera específica, las normas que afectan las condiciones laborales y salariales de los maestros como tópicos dominantes.

De allí que la promulgación de estos decretos haya tenido como correlato las luchas y movilizaciones más arduas del magisterio, pues en el fondo se trata de la dignificación y profesionalización del ejercicio docente con to- 
das las implicaciones económicas y sociales derivadas de la defensa de los logros y aspiraciones del gremio frente a las constantes reformas y contrarreformas de corte neoliberal accionadas desde la administración pública. De esta confrontación ha surgido en el seno del movimiento magisterial, sobre todo en su dirigencia y entre algunos de los intelectuales vinculados desde los comienzos del Movimiento Pedagógico a los CEID $^{6}$ y a la revista Educación y Cultura, un tipo de discurso opuesto al oficial, que se ha ocupado de replicar las políticas educativas, las ha cuestionado y, en muchas ocasiones, ha desentrañado sus lógicas mostrando cómo detrás del aparato discursivo aparentemente neutro de la norma, se postulan intereses económicos y se imponen las tesis del neoliberalismo en la educación.

Este ejercicio discursivo se ha convertido, no obstante su intención crítica, en una magnificación de las políticas de Estado, magnificación del adversario que se vuelve contra el maestro mismo, pues este termina reduciendo toda su capacidad para debatir y proponer al cuestionamiento de la política, y adoptando en últimas posturas cómodas, siempre amparado en que la ley se lo impide. Al respecto, en el artículo «El Movimiento pedagógico: estado actual y perspectivas», publicado en Educación y Cultura No. 77, Martínez Boom afirma:

Me pregunto ¿por qué tanta relación de los maestros con la ley? Los maestros son los que magnifican la ley, magnifican el Estado y a toda hora, están mencionando las leyes... son especialistas en citar decretos, diciendo, por ejemplo: "ay... es que el ministerio... Que el decreto número tal y tal... la resolución...» (...) hay una magnificación de la ley (...) no sé si esa sea una postura del maestro como para cubrirse en salud, cuando dice "yo no puedo hacer estas cosas... y justifico lo que no puedo hacer o lo que no quiero hacer... o lo que me da pereza mental hacer (...) Allí está implícita la relación con la política (Ibíd., 2007, pp. 73-76).

Este tipo de discurso, como señala Angenot, suele convertirse en una suerte de doxa que hace que los maestros se queden, sin saberlo ellos mismos, estancados en la dependencia de las ideas que atacan. El discurso se torna entonces «recesivo, una manera de responder a la coyuntura acusando ciertas dominantes, sin progresar sin embargo más allá»(Angenot, 1989). Habría que preguntarse entonces, por cuál ha sido el efecto de este tipo de discursos en la construcción de las identidades profesionales de los maestros,

6 Es importante señalar que la Revista Educación y Cultura se ha nutrido tradicionalmente de las opiniones y ensayos de intelectuales e investigadores que están por fuera del magisterio, vinculados a las universidades y/o a grupos de investigación; pero que han acompañado desde sus orígenes el Movimiento Pedagógico. 
en la recuperación del discurso pedagógico y en sus formas de auto representarse, como se lo propuso en sus inicios el Movimiento Pedagógico-MP.

La sobredeterminación del discurso de la ley en el discurso gremial parece haber "cerrado» los horizontes para que los maestros encontraran formas alternativas de oposición y lograran romper el cerco que impone el discurso hegemónico. Veamos algunos ejemplos de este fenómeno tomados de la revista Educación y Cultura. En el artículo "La crisis financiera y el caos administrativo de la Educación Pública» (No. 2, sep. 1984), el profesor Abel Rodríguez, quien por entonces fungía como Presidente de FECODE, señala: "La crisis financiera y administrativa tiene sus raíces en dos problemas básicos: la insuficiencia de recursos y la falta de unidad entre la dirección, financiamiento y administración del servicio».

El articulista acusa a estos fenómenos de ser responsables de «la crítica situación laboral del magisterio». El artículo muestra en cifras el déficit presupuestal del Ministerio de Educación y recurre, mediante asociaciones antitéticas, a evidenciar el trasfondo económico del asunto y poner en evidencia que el maestro (sus condiciones socioeconómicas) termina siendo el afectado directo de las regulaciones de la norma:

(...) la pedagogía ya no solo ha sido sustituida por la psicología sino también por la contabilidad. Ello explica por qué la política educativa gubernamental se define en el Ministerio de Hacienda y no en el de Educación (...)

La ley 43 se propuso nacionalizar los costos de funcionamiento de la educación primaria y secundaria, pero no lo consiguió. En cambio, sí logró crear un caos, con el cual, los primeros lesionados han sido los educadores.

Más adelante, en el mismo artículo, el profesor Rodríguez expone la propuesta de «FECODE frente a la crisis», en la que la organización aboga por la «nacionalización total y definitiva del servicio educativo oficial» a través de:

- El aumento del porcentaje de los ingresos ordinarios de la Nación destinados a la educación hasta llegar al 25\%, tal como lo previó la ley 46 de 1971.

- El aumento de la participación de la educación en el impuesto a las ventas.

- Establecimiento de una participación porcentual de la educación en las rentas propias de los establecimientos públicos nacionales, de tal manera que se le dé cumplimiento a lo consagrado en el artículo 11 de la Reforma Constitucional aprobada por el plebiscito de 1957.

- El establecimiento de una sobretasa al impuesto de rentas de capital con destino a la educación. 
- La modificación de las normas que regulan el sistema de distribución, transferencias, giros, depósitos y control de los recursos destinados a la educación.

- La expedición de un régimen salarial y prestacional único para todo el personal docente al servicio de la educación oficial.

Como se puede apreciar en los apartados del artículo, la financiación de la educación aparece como la preocupación central del discurso gremial, en el que se visibiliza la constante lucha del magisterio por mejorar sus condiciones y aún por exigir la aplicación de normas constitucionales que nunca se cumplieron, como lo evidencia el numeral 3 del anterior articulado. Quizá estas reclamaciones dedicadas a la política Educativa -las que constituyen una constante en los artículos de la revista Educación y Cultura- hayan conducido a que desde el discurso hegemónico se utilizaran como evidencias de las pretensiones puramente económicas del magisterio y a que en los titulares de prensa -lugar de reproducción privilegiada del discurso hegemónico- se utilicen estrategias argumentativas de maximización, tergiversación, parcialización, etc., para reforzar la idea de que los maestros solo persiguen intereses monetarios y que son actores conflictivos. Así se expresan algunos titulares de prensa del periódico El Tiempo: «Maestros reciben 26 primas anuales» (SL70); «Suben salarios de comunicaciones y maestros: FeCODE anuncia paro» (HS80); "Revelan tabla de alza salarial para maestros y persiste el paro». «El estado pagará 15 mil millones a los maestros».

Otros artículos de la Revista Educación y Cultura, dedicados a la discusión de las políticas para el sector, igualmente se ocupan del análisis de los fundamentos sociopolíticos de las reformas y destacan, por ejemplo «el continuismo neoliberal, la recuperación de la tradición católica y un enfoque populista demagógico» (Téllez, 1984, pp. 49-54). El artículo discute el Plan de Desarrollo del gobierno Betancourt (1982-1986), periodo en el que ya se ha desatado la reforma neoliberal de todas las economías latinoamericanas y reitera, como en el caso anterior, esa sobredeterminación de la economía en el discurso gremial:

(...) la crisis fiscal del Estado como justificación a una política orientada a la reducción de los costos (...), el incremento del crédito educativo, el desmonte de la "nacionalización» que busca redistribuir las obligaciones fiscales entre el gobierno central y las secciones departamentales o municipales (...) la manera como se incrementan mecanismos que permiten de manera abierta o disfrazada la transferencia de recursos del Estado hacia el sector privado de la Educación.

Estos dos primeros artículos que se publicaron en el segundo número de Educación y Cultura (1984) constituyen una especie de abrebocas a lo que 
serán, en adelante, los discursos del gremio frente al tema de las políticas educativas: reformas, planes de desarrollo, leyes. En la medida en que arrecian las reformas neoliberales en la economía nacional, y sobre todo en los últimos gobiernos de Pastrana (1998-2002) y Uribe Vélez (2002-2010), los temas de política educativa se tornan predominantes en los artículos de la revista. El discurso manifiesto tiene una clara connotación ideológica de resistencia a las políticas de Estado en materia educativa y aún de aspectos macroeconómicos del país.

La agenda temática de la revista estará dedicada al cuestionamiento de las políticas educativas. Veamos los títulos de algunos artículos en los distintos números de la revista: «Neoliberalismo y Educación», No. 55; «El 012 Encrucijada de la Educación Pública», No. 58; «Calidad de la Educación», No. 60; "La revolución educativa: más de lo mismo», No. 62; «Estándares curriculares», No. 63; "La Educación Pública, un derecho fundamental», No. 64; "Competencias ciudadanas», No. 67; "Hacia el estatuto docente único», No. 68; «Economía política de la reforma educativa en América latina», No. 79.

En todos estos números de la revista, el informe central y los editoriales están dedicados al análisis político:

Con el título de "revolución educativa» el candidato Álvaro Uribe Vélez presentó al país una propuesta, que luego como Presidente de la República se transformó en la continuación de la política educativa del gobierno de Pastrana, y que no es otra cosa que la estrategia del Banco Mundial y el Fondo Monetario Internacional que de tiempo atrás le han impuesto al país.

Editorial Revista No. 62. Abril 2003

El Plan Nacional de Desarrollo 2002-2006 del gobierno del presidente Uribe, presentado al Congreso de la República (...) es una repetición de las políticas en curso, bajo la impronta del modelo neoliberal y los ordenamientos del Fondo Monetario Internacional y del denominado Acuerdo Stand By.

Revista No. 62. pp. 7-11. Abril 2003

Los gobiernos neoliberales han desatado una verdadera guerra contra las escuelas, los maestros y los elementos más progresistas de la Ley General de Educación. Con el Plan de Desarrollo "Hacia un Estado comunitario» se declara la desaparición paulatina de la escuela pública. 
Una y otra vez los artículos vuelven sobre el tema de la financiación de la educación y muestran las estrategias de administración de los gobiernos de turno para someter la educación a las lógicas del mercado. El editorial de la revista No. 55, por ejemplo, se detiene en analizar las tesis del neoliberalismo y su impacto en la educación. El análisis se carga del lenguaje del mercado:

Se trata de una empresa productora de la mercancía denominada educación, sujeta al libre juego del mercado entre la oferta y la demanda, bajo los estándares de la más alta competitividad, gerenciada con criterios de rentabilidad, orientada a la globalización de la actividad humana, con altos rendimientos monetarios de eficiencia, donde los estudiantes son clientes del servicio al que se le aplica equidad, cobertura y calidad entendidos en lenguaje empresarial, regido por el Estado, pero financiado por los usuarios.

Editorial Revista No. 55

Este tipo de lenguaje manifiesta una carga ideológico-política que se torna reiterativa en los distintos artículos («Neoliberalismo y profesorado», «Neoliberalismo y Educación», «El contexto de las políticas educativas: globalización y sentido de la política social», Revista No. 55), pero que parece cegar la capacidad analítica para abrir alternativas discursivas al debate político sobre la educación.

Hasta aquí interesa señalar que mientras el discurso gremial aparece centrado en la problemática socioeconómica, se han ido tejiendo otros discursos cuyas consecuencias devienen en acciones prácticas que han afectado y afectan la cotidianidad del maestro. Se trata de cómo los discursos de la política educativa descienden al plano de las acciones y devienen formas, estrategias y marcos cognitivos que orientan acciones críticas del oficio de maestro -como su formación y su profesionalización-que forman parte de la agenda política pero que no se advierten de manera clara en las discusiones de los aspectos macro de la política educativa y que han sorprendido al magisterio sin las herramientas para enfrentarlas al aplazar la discusión y la construcción de un discurso pedagógico capaz de resistir desde espacios alternativos la política de Estado.

\section{El discurso de la formación y la profesionalización docente}

Es evidente que la formación de maestros es también asunto de política educativa, solo que la discusión ya no se ocupa en estricto sentido de la asignación y distribución de los recursos, sino de las estrategias y acciones prácticas encaminadas a la formación docente inicial y en ejercicio. 
El mecanismo lo constituyeron, durante mucho tiempo, los cursos para ascenso en el escalafón docente, ofertados principalmente por las universidades privadas que se sumaron, sin muchos escrúpulos, a la «feria del crédito» sin ninguna proyección pedagógica y emancipadora del maestro. Simplemente aprovecharon las normas legales para ofertar cursos de 45 horas que otorgaban determinado número de créditos cuyo fin último era el ascenso en el escalafón.

En esta lógica, la formación docente fue un proceso de instrumentalización consistente en la capacitación para que el maestro:

(...) administre bien unos programas (Guías de la Misión alemana, Decreto 1710, Reforma Curricular, Programa Escuela nueva). Dicha capacitación se fundamenta en el supuesto de que como profesional no tiene las capacidades para tomar autónomamente sus propias decisiones, razón por la cual se le entregan las guías, los manuales, los textos, los programas, los objetivos y en muchos casos, hasta las actividades para desarrollar en clase (Álvarez, 1996, p. 6).

Desde esta manera de comprender la formación, se legitimó también una concepción del maestro auspiciada por el decreto 1710, que durante mucho tiempo consolidó el imaginario social del maestro como un ser deficitario, una suerte de minusválido mental, incapaz de autodeterminar(se) en relación con las exigencias de su propio trabajo.

Ahora, los cambios en la retórica educativa de finales de los ochenta construyeron un nuevo discurso centrado en el lenguaje de las competencias. Dicho lenguaje, no obstante sus múltiples significados, se ha decantado en el discurso oficial y constituye «el concepto fundacional» de las nuevas retóricas sobre educación:

La necesidad de un nuevo rol docente ocupa un lugar destacado en la retórica educativa actual, sobre todo de cara al siglo xxı, y a la construcción de una nueva educación. El perfil y el rol pre-figurado del docente han terminado por configurar un largo listado de competencias deseadas, en el que confluyen hoy, contradictoriamente, postulados inspirados en la retórica del capital humano y los enfoques eficientistas de la educación, y postulados largamente acuñados por las corrientes progresistas, la pedagogía crítica y los movimientos de renovación educativa, y que hoy han pasado a formar parte de la retórica de la reforma educativa mundial (Torres, 2004, p. 33).

Lo que aparece ya enquistado en el discurso de la formación docente es la idea de las competencias, unas competencias deseadas en las que se cruzan y entrecruzan las habilidades del técnico, la capacidad crítica del 
intelectual, el espíritu creador del artista, el rigor analítico del investigador, etc., sin que resulte claro a qué modelo educativo y de sociedad se pretende responder y menos aún, cómo lograr articular dimensiones a veces diametralmente opuestas.

El discurso de «las competencias» monopolizó las representaciones sobre la evaluación de los aprendizajes y sobre la formación y la evaluación de los docentes. La revista de Educación y Cultura dedicó varios de sus números al debate de las competencias y el discurso terminó naturalizándose. Luego de las discusiones sobre el trasfondo economicista y mercantil del concepto, ya no quedó otra cosa que el término incrustado, primero en el discurso gremial que lo rebatía («Las pruebas de estado y la evaluación por competencias» No. 56, «Evaluación por competencias, control ideológico para la contrarreforma educativa» No. 56, «Los estándares y las competencias: La ley de libertad de empresa», No. 63); y luego en el discurso pedagógico, al que entró impuesto por los programas de formación de docentes y por las directrices del ICFES al establecer las competencias procedimentales, las competencias argumentativas y las competencias propositivas como pautas de la evaluación.

El término se acomodó en todas las propuestas de formación de docentes en ejercicio, y pronto se articuló a los Programas de Formación Permanente de Docentes PFPD. La naturalización del discurso no solo corrió a cargo del debate ideológico político y de la legislación, sino de su incorporación progresiva en el discurso de los maestros «forzados» a planear currículos por competencias, a preparar(se) para las pruebas de competencias y formarse en el discurso de las competencias, que se desbordó en los planes y programas de formación docente en las facultades de Educación.

En la formación de docentes en ejercicio la irrupción del nuevo discurso no cambió, sin embargo, las lógicas de su administración, históricamente asignada a la Universidad. El ente universitario encargado por el Estado de adelantar dichos procesos, ofrece ahora, en lugar de cursos dispersos para ascenso en el escalafón, los PFPD, atendiendo a las demandas de capacitación planteadas por las Secretarías de Educación regionales que definen los marcos conceptuales, las áreas temáticas y las «necesidades» de formación. Lo que se traduce en una nueva negación del maestro como sujeto autónomo responsable, él mismo, de definir sus procesos formativos; pero, además, en una estrategia para acentuar las políticas que recogen las retóricas del capital humano, traducidas en la eficiencia y la eficacia que se mueven al interior del discurso de las competencias. 
Es una clara estrategia de control sobre los proceso formativos en los que la universidad apenas actúa como la agencia de distribución del discurso hegemónico y se mantiene en las dinámicas del mercado a la expectativa de las «demandas de formación» para empaquetar los programas con los contenidos y las cargas ideológicas que requiere el establecimiento. En el trasfondo se advierten las lógicas del mercado al que la universidad tampoco puede sustraerse. Lo que parece primar es el interés monetario en el que la universidad, como cualquier agencia vendedora de servicios, está atenta a la «demanda» que propone para los maestros el órgano regional, licita, y si gana, cumple con las demandas del cliente: las Secretarías de Educación, aunque, dicho sea de paso, estas entidades se limiten solo al control y vigilancia, pues el costo final de los cursos recae en los maestros.

La Universidad Nacional fue quizá la primera institución universitaria que, habiendo cerrado años atrás su facultad de educación, emprendió la tarea legitimadora del discurso. Allí se diseñaron las primeras pruebas censales por competencias, se produjeron los primeros libros y se emprendieron los programas de Fortalecimiento de la capacidad científica docente, en el programa RED, en cuyo seno también surgieron las denominadas Acciones focalizadas, orientadas a subsanar en cursos de un año, orientados a los maestros, las deficiencias de los alumnos, evidenciadas en los análisis estadísticos de las pruebas SABER.

La Universidad, actuando como agencia de legitimación del discurso hegemónico, se encargó entonces de la promulgación y naturalización del concepto de competencia tal y como lo requería la política oficial, como se evidencia en el libro Competencias y proyecto pedagógico, cuyos artículos defienden y naturalizan el discurso de las competencias como el modelo a seguir: "La evaluación de competencias: una respuesta de la Universidad Nacional de Colombia a su vocación educadora en el horizonte de la Historia», "Una prueba de evaluación de competencias académicas como proyecto», «Educar para el desarrollo de las competencias: una propuesta para reflexionar», «El lenguaje y la literatura en la educación básica y media: competencias y desempeños», «En la búsqueda del asombro de los niños y jóvenes de hoy». Todos los títulos y los contenidos de los artículos constituyen una defensa abierta del tema de las competencias, el interés legitimador del discurso destierra el análisis crítico, y aún se declara que el texto entero es producto del contrato establecido entre UN y SED:

Las reflexiones, ideas y elementos que se exponen aquí corresponden a la comprensión alcanzada y a la mirada construida, durante el desarrollo del proyecto de evaluación de competencias básicas que adelanta la Universidad Nacional para la Secretaría de Educación Distrital de Santa Fe de Bogotá (Bogoya, 2000, p. 7). 
Las competencias son una forma de contradiscurso hegemónico (cf., Angenot) para reintroducir postulados que ya se habían desgastado en los modelos de desarrollo de los años 60 y 70. En el artículo «¿Sabemos de qué hablamos cuando usamos el término competencias? Historia, sentido y contextos» (Revista Educación y Cultura No. 58) las autoras señalan que:

(...) dentro del discurso educativo contemporáneo adquiere importancia el concepto de desarrollo que fuera central en los modelos y teorías de los años 60 y 70 , el cual suponía la existencia de países desarrollados (...) y países en vía de desarrollo (...) que el progreso tecnológico generaba en forma automática progreso social (...) que el sistema educativo debía ser funcional a los requerimientos del mercado laboral, produciendo los recursos humanos requeridos para sus exigencias (...) (Bacarat y Graziano, Ibíd.).

Estas premisas se reintroducen bajo el manto de LAS COMPETENCIAS, puestas ahora en la orientación pedagógica del discurso del desarrollo. De allí que las pretensiones del discurso educativo de finales de los ochenta para construir saberes significativos fueran desplazadas por las competencias, puesto que los primeros resultaban menos estables, difíciles de instaurar en los currículos; mientras que las competencias definen los atributos concretos de los sujetos en el aspecto económico-laboral que requiere el mercado del trabajo. Por este camino las premisas del desarrollo se actualizan en la palabra COMPETENCIA que aparece como una varita mágica que soluciona los problemas y cuestionamientos que el cambio tecnológico y la globalización han impuesto a las antiguas maneras de vincular las calificaciones con la formación profesional (Ibíd.).

Este discurso oficial de las competencias, que desató transformaciones concretas para los diseños curriculares y las prácticas pedagógicas, parece no encontrar entre los maestros alternativas distintas a las que impone la hegemonía discursiva, esto es la contrarréplica o -como se verá a continuación- la construcción de unas representaciones de la formación sobre la idea del deber ser, lo cual puede explicarse debido a la falta de reflexión pedagógica, sacrificada por la magnificación ya aludida de la ley.

Aunque el tema de las competencias - del que se ocupa con amplitud la revista Educación y Cultura- tenga implicaciones directas en la formación de maestros y haya servido como plataforma para centralizar los procesos de formación, es importante aclarar que éste no constituye el discurso del gremio en materia de su formación. No existe en los artículos analizados de la revista Educación y Cultura una producción discursiva suficiente que permita pensar que el tema de la formación de los maestros haya trascendido más allá de la réplica a las políticas de Estado y, en los casos afortunados, se reduce al deber ser. 
Como puede apreciarse a lo largo de este recorrido por los artículos de Educación y Cultura, la réplica es quizá la característica domínate del discurso gremial. Angenot nos ha advertido ya sobre «cómo los pensamientos considerados contestatarios se desarrollan en la esfera de influencia de la hegemonía invisible contra la cual procuran poner su crítica, cómo se infiltra constantemente en ellas el discurso dominante que rechazan» (Angenot, 1989).

Mientras se le entrega [al maestro] la inmensa responsabilidad de formar hombres, se desconoce prácticamente la importancia social de su trabajo. Mientras se le exige una gran capacidad profesional, la formación que se le ofrece se restringe exclusivamente a la parte operativa del conocimiento. Se le exige una vocación que supuestamente le viene con la sangre, pero no se le reconoce una identidad intelectual (Martínez y Álvarez, 1990, p. 5. Revista No. 20).

Los distintos artículos señalan con frecuencia las debilidades, los quiebres, las contradicciones de las disposiciones, pero son parcos en mostrar las alternativas que de manera cierta discurren en las prácticas cotidianas de los maestros, tema para el que no alcanzan las páginas de la revista. El discurso de la formación docente en la revista Educación y Cultura discurre entre la réplica y el deber ser, con muy pocos artículos que muestren procesos y apuestas reales de los maestros para «oponerlas» a las que determina el discurso oficial. Es como si el magisterio, obcecado en el debate político, hubiese perdido la capacidad de proponer y actuar como lo hizo en los inicios del MP.

(...) la capacitación en ejercicio ha de ser concebida como un proceso de formación permanente. La idea de que el maestro sea un profesional de la educación implica que debe estar investigando, actualizándose y experimentado permanentemente (...) De allí que sea necesario un modelo en el que esto sea posible, donde todo lo que él haga en desarrollo de su labor docente sea objeto de reflexión y de confrontación académica entre sus pares (Álvarez, 1996, p. 6).

Obsérvese que se trata del deber ser, de propuestas que raras veces tienen eco en la formulación de políticas. En los casos "afortunados», las iniciativas gremiales son recogidas (cooptadas) en los discursos oficiales, pero tergiversadas en su práctica, es decir, empleadas como retórica, como macro-visiones para lograr la homogenización y la distinción entre Estado y maestros, invocando los mismos discursos pero proyectando acciones diferentes. Tal es el caso de la idea de formación permanente acogida en el discurso oficial pero centralizada y controlada en su totalidad en la figura del los PFPD que regula el Estado a través de las Secretarías de Educación, en 
un claro ejemplo de cooptación del discurso. Otros ejemplos de formación como deber ser son:

El reconocimiento y valoración del maestro como un protagonista del proceso educativo, cuyo saber debe ser recuperado y repensado (...) Los procesos de formación surgen de la discusión y concertación con los maestros y se construyen a partir de proyectos que adelantan los docentes (...) La formación permanente debe proyectarse hacia la consolidación de procesos de autoformación, articulada a procesos de investigación que le permita al maestro constituirse en investigador de su propia práctica (Amaya, 1996, p. 13).

Se trata de ideas apoyadas en el deber ser, de propuestas que confrontan los «programas tradicionales» con «los programas modernos», que señalan los elementos de "la crisis», que proponen alternativas; pero que no descienden al plano de las realizaciones, como sí lo ha logrado, entretanto, el discurso hegemónico.

\section{El discurso de la calidad de la educación}

Este es el segmento del discurso educativo en el que se hace más visible el uso de retóricas comunes entre unos y otros actores discursivos (cf. Ratinoff, 1994). En efecto, Estado y gremio invocan de manera recurrente el problema de la calidad como estrategia para posicionarse discursivamente. Sin embargo, la topicalización de la temática pone en evidencia los fines encontrados: mientras para el Estado y sus representantes la calidad de la educación es un asunto fiscal que compromete la eficiencia y la eficacia con el mínimo de recursos, y se manifiesta en el control terminal de los resultados de las pruebas nacionales e internacionales -PISA, TIMMS, ICFES, ECAES, SABER, etc.-, para los maestros, desde los orígenes mismos del MP, es:

[un asunto de rescate de] (...) la educación pública como columna vertebral del desarrollo cultural del país y como pilar ineludible de la soberanía nacional. La educación pública no es un efecto, un «servicio» más; es un proceso cultural, condicionado social e históricamente, que posee una cierta autonomía con respecto al Estado y a los sucesivos gobiernos. Su existencia corresponde al ejercicio por parte de amplios sectores sociales, del derecho de educarse (...) El eje de la defensa de la calidad de la educación pública debe ser el rescate del oficio del educador y de su identidad intelectual (Mockus, 1984, p. 32 Revista No. 2).

El debate en torno a la calidad de la educación pública vuelve a poner en el centro la figura del maestro, la constitución de su identidad profesional $y$, en consecuencia, sus procesos formativos, su dignificación y empodera- 
miento como sujeto de saber. El editorial de la revista 60 (junio de 2002) dice en uno de sus apartados:

(...) No cabe duda de que los grupos gobernantes recurren con frecuencia a la retórica como manto ideológico para ejecutar la política de ajuste. A menudo, para reprimir hablan de calidad; para erosionar las plantas de personal echan mano de las metas de calidad; para cambiar el esquema de asignaciones de recursos se basan en la calidad y la eficiencia; para desprestigiar la educación pública construyen un modelo de calidad a favor de la educación privada. Aunque algunas veces, se ha convertido en "una palabra vacía» y en otras, en mero pretexto, no puede ocultarse la manera como el concepto de calidad ha servido para arropar la política de ajuste bajo el impacto de la empresarización, la competitividad y la rentabilidad.

El discurso del gremio cuestiona profundamente la idea de calidad que defiende la hegemonía, y postula una en franca oposición con dichas lógicas, defendiendo el protagonismo del Movimiento Pedagógico como vector de calidad; aboga por devolverle a la pedagogía su estatus: "sin pedagogía, toda referencia a la educación y su calidad queda mortalmente ligada al implacable mundo del mercado».

Todos los artículos de este número de la revista señalan el problema de calidad diferenciándolo de las tesis de los gobiernos de turno, centradas en las leyes del mercado. Podría decirse que el discurso se torna antinómico:

- Empresa estudiantil versus escuela;

- Orientación al mercado versus reconstrucción de identidades colectivas y empoderamiento de los sujetos colectivos;

- Estandarización de procesos versus prácticas pedagógicas diferenciadas;

- Privatización versus defensa de la educación pública.

En el discurso oficial, el problema de la calidad de la educación está inspirado en los principios empresariales de lucro, según los maestros, mientras que para ellos se trata de "una permanente lucha ideológica sobre el control de los contenidos de la educación (...) el magisterio contrapone una visión de poder centrada en los valores universales de la democracia y la cultura». Sin embargo, comparten posturas reconociéndose ambos actores explícitamente respecto a las deficiencias de desempeños en materia de lectura, escritura y cálculo matemático, entre otros dominios, aunque el gremio insista en que los factores generadores de las deficiencias no son iguales a los señalados por el Estado, pues mientras este los achaca a los profesores, ellos son enfáticos en señalar los elementos que se soslayan, tales como la implementación de las dobles jornadas, la promoción automática, la carencia de recursos, la sustitución del preescolar con la figura de las madres 
comunitarias, la eliminación de áreas tan importantes de formación como la educación física y la expresión artística, y el insalvable problema de las diferencias de capital simbólico y cultural entre los niños de los sectores más desprotegidos de la población, a los que atiende la educación pública, y los niños de los estratos medios y altos que se educan en el servicio educativo privado.

En el debate sobre la calidad de la educación que se adelanta desde la revista Educación y Cultura, es recurrente también el tópico de la evaluación, que se presenta como «instrumento idóneo para llevar a la realidad los fundamentos de la doctrina neoliberal y conservadora» (Díaz Ballén, 2008, p. 30, Revista No. 79). El discurso -ya naturalizado- de las competencias, es recogido por el Estado y/o gobierno de turno para señalar la mala calidad de la educación a partir de los resultados de las pruebas por competencias. De esta lógica no escapa la evaluación docente que parece regida por los mismos criterios: "las políticas educativas en relación con la concepción de Evaluación de Docentes está fundamentada y dirigida, por un parte, en una racionalidad técnico instrumentalista y por otra, en una racionalidad económica» (Ibíd.).

Como puede apreciarse a lo largo de estos tres factores de política educativa, el tópico dominante lo constituye la discusión del problema financiero de la educación. La política neoliberal, las lógicas del mercado, la contrarreforma neoliberal, el ajuste fiscal, el eficientísimo, la racionalidad del gasto, la competitividad, las evaluaciones masivas, la privatización, la evaluación sanción, etc., se constituyen en las unidades léxicas dominantes con las que se construye el discurso del gremio para desarrollar a partir de ellas los argumentos que opone al discurso hegemónico.

La discusión final de los discursos pone en evidencia que no es posible asumir los temas de política educativa sin referirse directa o indirectamente al problema de la administración de los recursos; pero que, igualmente, la sobre-determinación del discurso produce un efecto contrario al que pretende resistir, pues en últimas naturaliza, sedimenta el discurso hegemónico mientras siega la posibilidad de pensar en las alternativas, que como puede apreciarse, no surgen de la simple réplica.

\section{La imagen social del maestro}

Es otro de los tópicos dominantes en el corpus seleccionado para analizar el discurso del gremio. La imagen social del maestro no es sino un correlato del discurso político. Las representaciones construidas sobre el maestro son naturalizaciones discursivas, estrategias de poder «que se ponen en 
operación para aplicar el poder efectivamente o para mantenerlo» (Foucault, 2005, p. 51). En el fondo opera el sistema de diferenciaciones (Ibíd.) económicas, culturales, de ubicación en las jerarquías sociales, etc., en las que emergió la figura del maestro.

Como en el caso anterior, son igualmente escasos los artículos que abordan de manera significativa la imagen social del maestro en las circunstancias históricas de cada momento, y la mayoría se refieren a las imágenes fundacionales ya desarrolladas en el apartado 2 de este trabajo.

Una vez más es el discurso hegemónico el que construye imágenes sociales del maestro, que aunque no se refieren directamente al sujeto, lo colectivizan para presentarlo como problema. Estas son las imágenes del maestro como gremio. Veamos, en los siguientes apartados citados por Torres, (2000) cómo desde el discurso hegemónico se representan las organizaciones sindicales de maestros:

(...) Cuando los gobiernos no llegan a un acuerdo con los poderosos sindicatos centrales respecto a las condiciones de empleo de los maestros, la acción colectiva puede perturbar la educación y a veces culminar con una parálisis política, como ha ocurrido en Bolivia, el Perú y otros países en los últimos años (...) Los sistemas prevalecientes de gastos y administración suelen proteger los intereses de los maestros (Banco Mundial, 1996, p. 153).

Los sindicatos docentes militantes rechazan cualquier sistema de evaluaciones en torno al acceso y a la promoción (Puryear, 1997, p. 12).

Aunque en su interior hay matices, el Colegio de Profesores desarrolla un discurso de oposición o crítica estatal, con fundamentos más ideológico-políticos globales que fundamentos propiamente profesionales (Núñez, 1999, p. 193).

Mientras el aparato discursivo hegemónico construye representaciones negativas de las organizaciones sindicales del magisterio, para estas la organización sindical constituye una de las primeras «imágenes positivas» propias. En un artículo de la revista Educación y Cultura 3 (marzo de 1985), el profesor Abel Rodríguez habla de una «nueva imagen del maestro», que "todavía no alcanza a reflejar ni la literatura ni nuestra lenta historiografía. Se trata de la imagen del maestro sindicalizado, del maestro luchador por su derechos e intereses».

Esta imagen del maestro sindicalizado no es la del que "hace paros», "que no trabaja», como lo muestran los medios; se trata de una imagen 
como la que impulsó el mp que «definió una concepción sobre el maestro y erigió una triple dimensión que precisaba los horizontes y el sentido de su quehacer, su función y su papel: la concepción del maestro como trabajador, como intelectual y ciudadano» (Editorial. Educación y Cultura No. 77.) Es la imagen del maestro fundacional del MP, que quedó expresada así en las conclusiones del XII Congreso de FECODE:

(...) se trata de que el magisterio, bajo la orientación de su organización sindical, aborde su actividad diaria en dos campos que se complementan y no se excluyen:

El maestro como trabajador de la cultura, con compromisos pedagógicos que necesita rescatar para colocarlos al servicio de las masas y con una práctica pedagógica que contribuya la liberación nacional (...) el maestro como ciudadano luchador por sus derechos democráticos y políticos (Conclusiones del xII Congreso de FECODE. Revista No. 1, pp. 43).

Este ideario, que fue asumido como plataforma de trabajo del Movimiento Pedagógico MP, erigido como resultado de la movilización que desembocó en la promulgación del Estatuto Docente (decreto 2277 de 1979), constituye el discurso que el gremio de los maestros ha sostenido durante los últimos 25 años. Las representaciones discursivas sobre el docente y su labor, que aparecen en Educación y Cultura, son desarrollos de los postulados del MP y/o réplicas a las políticas de Estado en torno a la profesión docente. Cuando se trata de replicar las políticas, la despedagogización, la desprofesionalización, la pauperización, aparecen como lexías estructurantes del discurso, en tanto que el trabajo, la recomposición y la lucha se constituyen en las tareas que deben asumir los nuevos maestros:

En el conjunto actual de amenazas contra la profesión docente y la educación pública, no hay lugar para el escepticismo y la resignación de las visiones catastróficas que le ponen fin al Movimiento Pedagógico. No es tiempo de dudas, de vacilaciones o condenas, sino de trabajo, recomposición, reorganización y lucha (Editorial Revista No. 77).

Desde la perspectiva del discurso hegemónico se construyen «nuevas representaciones» apelando al lenguaje del mercado: los maestros son gasto, problema, insumo, incompetentes, ineficientes, politizados, etc. (cf. Torres, 2000); mientras, las representaciones del gremio se abren en dos direcciones: una que se construye apelando a las retóricas de la dignidad, la beligerancia, la protesta, y otra que destaca la acción educativa como esencia de la actividad profesional. Ejemplos de estas representaciones en los artículos de la Revista: 
El magisterio debe comprometerse con el cambio de imagen que se tiene del docente como víctima o culpable de lo malo que sucede en la institución educativa, para ubicarse con importancia en la comunidad en la que actúa. En otras palabras, debemos seguir posicionando a los docentes como unos reales profesionales de la educación, para ser capaces de producir innovaciones en el campo de la educación y la pedagogía. Hemos de comprender que a través de la acción educativa como esencia de la actividad profesional lograremos que los niños y los jóvenes se apropien de manera creadora del conocimiento y participen en la sociedad como ciudadanos colombianos pensantes y deliberantes (Nieves Celio, 2003, p. 47. Revista No. 64).

Obsérvese que se trata de una imagen construida desde el deber ser, igual a la que se construyó en torno a la formación. La dicotomía entre el ideario y la acción, característica de la disputa entre teoría y práctica, se hace visible cuando se contrasta con la idea del maestro como activista sindical. Aquí ya no se trata de deberes como posibilidades, sino de estrategias concretas enunciadas como acción colectiva de resistencia:

Nos seguiremos oponiendo a la aprobación del acto legislativo No. 12, desplegaremos hasta el final la protesta de un paro nacional indefinido, le anunciamos la más férrea batalla contra todas las medidas subsecuentes que pretenderá aprobar en el segundo semestre y lo responsabilizamos a usted y a este gobierno oprobioso ante el país y la historia, de la tragedia en que serán sumidas la EDUCACIón y la salud públicas de aprobarse esta reforma constitucional (Carta de FECODE al Ministro de Hacienda. Revista No. 58).

Estas distintas visiones muestran también las coyunturas sociopolíticas en las que se construyen los discursos sociales y hacen evidente esa tensión que ocurrió al interior de FECODE, entre quienes desde los CEID y el MP defendían la investigación y la reflexión pedagógica como alternativas para la construcción de la imagen social del educador como intelectual y trabajador de la cultura, y quienes pensaban que «solo cambiando el sistema cambiará la educación».

En el fondo se reproduce una condición centradora del discurso hegemónico que obliga a su recuperación permanente a través de la réplica que disputa su representación-construcción y que, en el caso de FECODE, hizo que primara el debate ideológico político sobre el discurso pedagógico y educativo. La política oficial absorbió el discurso del gremio e impidió que se visibilizaran otras alternativas de representación discursiva sobre los maestros y sobre la naturaleza de su profesión: 
Cómo no luchar contra esa política de recorte de las transferencia (...) Esta política da marcha atrás a los procesos de descentralización y autonomía que se habían ganado (...) Ello era y es completamente válido, pero significó abandonar aún más el trabajo en el ámbito del quehacer pedagógico de los maestros, la esencia y razón de ser del Movimiento pedagógico (Rodríguez, A., 2008, p. 21, Revista No. 78).

En esa particular coyuntura de análisis que constituye el periodo 19792005, caracterizado por la instauración del modelo neoliberal, el discurso de los maestros y sus formas de auto representación, se tornan más políticas, más centradas en el protagonismo del maestro como un sujeto «capaz de desafiar y transformar las condiciones y las situaciones que la globalización y sus políticas neoliberales le imponen a la educación pública y que buscan modificarla y adaptarla a las condiciones y nuevas realidades de la economía de los TLC (Editorial, Revista No. 77). Es, sin duda, la prevalencia del discurso de la réplica.

\section{El movimiento pedagógico}

Este último apartado constituye la evidencia más clara de la presencia de un discurso contra hegemónico cualitativamente diferenciado de las lógicas de la réplica, dominante en los discursos anteriores. Aunque en la revisión de las subcategorías propuestas (historia, orígenes, etc.) puedan advertirse las trazas de la fragmentación del discurso hegemónico al que alude Angenot, es evidente que en los orígenes, propósitos y acciones que emprende el MP, hay notorias rupturas con las formas de representación dominantes en torno a la figura del maestro, a la naturaleza política de la acción pedagógica y a las maneras de concebir el oficio.

\section{El discurso de los orígenes del MP}

Antes de proceder a mostrar las manifestaciones del discurso en el MP, es necesario poner algunas consideraciones históricas que, aunque no son el objetivo de este escrito, contribuyen a la comprensión de los fenómenos del contradiscurso como ruptura epistémica y como deslizamiento doxático (Angenot, 1989), tal como interesa a este trabajo.

Son varios los factores que desembocan en la creación del MP y en el posterior posicionamiento de un tipo de discurso sobre el maestro, la educación y la escuela, notoriamente diferenciado de las representaciones precedentes:

(...) la llegada a la dirección de FECODE de una nueva generación de dirigentes sindicales, el rompimiento con la izquierda autoritaria de 
una parte importante de esa generación, la conquista del Estatuto Docente, la implantación de la reforma curricular y el encuentro del sindicalismo y la izquierda con los intelectuales e investigadores de la pedagogía (Suárez, 2007, p. 27. Revista No. 77).

De esta serie de circunstancias, quizá haya que destacar el encuentro entre sindicalismo e intelectuales de la pedagogía como el factor más determinante para la construcción del discurso que sustentó la creación y posterior crecimiento del MP. En efecto, la presencia en los CEID de los investigadores e intelectuales, que ya habían avanzado en su esfuerzo por construir referentes teóricos para la comprensión de la pedagogía, permitió esa primera aproximación entre el discurso del activismo sindical -con todos sus matices ideológicos- y las elaboraciones teóricas de la pedagogía y del maestro, construidas por los intelectuales.

El encuentro entre unos y otros actores se constituyó también en encuentro entre dos tipos de discursos: uno que defendía las tesis de los radicalismos de la izquierda - SSolo si cambia el sistema cambiará la Educación», "Sobre las ruinas del Estado burgués se construirá un Estado proletario y en consecuencia el Sindicato y la escuela estarían al servicio de esta causa»- y otro surgido en el seno de los maestros, al que se plegaron, luego, los investigadores e intelectuales y cuya propuesta consistía en la creación de un movimiento pedagógico que en tanto que luchaba por la «liberación nacional», fortaleciera la democracia desde la escuela.

Como puede apreciarse en los enunciados, las dos concepciones se erigían en alternativas "contra hegemónicas», "pero ese tipo de Dios maligno, emisario de la hegemonía», al que alude Angenot, hacía que la preocupación por enfrentarla (lo que une) engendrara distintas maneras de representar la resistencia y allí se generara, entonces (lo que desune) «todo tipo de grupúsculos que oponen a las ideas y a los valores dominantes su ciencia, su historiosofía, su misma hermenéutica social y (por lo menos de modo embrionario) su estética, grupos cuyo axioma fundamental es poner en la delantera esta ruptura radical de la que se jactan» (Angenot, 1989).

En los orígenes discursivos del MP este fenómeno de fragmentación se hizo visible entre las dos grandes tendencias y, tal y como lo advierte Angenot, el enfrentamiento entre fracciones «sacudidas en sentido opuesto, parecen entonces indefectiblemente empujadas hacia la intolerancia y el dogmatismo, los medios de resistir que solo agravan los fraccionamientos» (lbíd.). De esta manera se oyeron las primeras voces de la izquierda radical descalificando a los colegas que no compartían sus tesis: 
(...) sectores de la izquierda presentes en los sindicatos y en FECODE, nos Ilamaban "los de las rondas infantiles», "Rin Rin Renacuajo», "reformistas de la Educación», "belisaristas», y en varias ocasiones nos tildaron de enemigos de la revolución y de la destrucción del régimen burgués, porque habíamos renunciado a la consigna "Solo si cambia el sistema cambiará la educación» (Dussán, 2007, p. 11. Revista No. 77).

(...) la iniciativa de impulsar el movimiento pedagógico fue objetada por varios grupos políticos que hacían presencia en la dirección de FECODE. Algunos de estos grupos, que sostenían la obsoleta consigna maximalista de que "solo si cambia el sistema cambiará la educación», calificaron el movimiento pedagógico como un movimiento reformista que desviaba el magisterio de sus verdaderos objetivos de lucha, los cuales se limitaban a la simple lucha reivindicativa y salarial. Para estos grupos los problemas de la educación, la enseñanza y la pedagogía eran asunto del sistema y no de los maestros, y la vigencia de una nueva pedagogía solo era posible bajo un supuesto gobierno revolucionario dirigido por el proletariado (Suárez, 2007, p. 27. Revista No. 77).

Obsérvese que en el lenguaje de los grupos de izquierda, se evidencia un tipo de discurso cuyo fin es la ridiculización de ese «nuevo adversario» al que desprestigian mediante los epítetos de la tradición retórica izquierdista. Por no estar de acuerdo con sus tesis, los «otros» son «reformistas de la educación, belisaristas, Rin Rines (expresión que en Colombia significa «sapo»), mientras los que así eran señalados se defendían diciendo que las tesis de sus adversarios eran obsoletas, reduccionistas, limitadas a la simple lucha reivindicativa y salarial». Esas formas de representar(se) las diferencias ideológicas entre los grupos que enfrentan la hegemonía es, justamente, lo que Angenot identifica como expresiones doxásticas del contradiscurso, estrategias hegemónicas para posicionarse discursivamente $y$, por tanto, evidencias de que el peso de la hegemonía está aún presente en los discursos de quienes la enfrentan.

Por este camino de confrontación discursiva, la hegemonía «que favorece el fraccionamiento de las periferias y este fraccionamiento múltiple todavía responde a su misma lógica» (Angenot, Ibíd.), hubiera logrado que el MP se diluyera en sus orígenes; pero las dinámicas del movimiento permitieron romper «el cerco discursivo» y lograron una ruptura epistémica, que se cristalizó en esa nueva manera de entender la lucha, que constituiría en adelante una propuesta discursiva liberada, un «mito educativo propio, con el cual alimentó (el magisterio) la ilusión de encontrar nuevos rumbos a la educación colombiana y provocar una transformación democrática de la enseñanza, la escuela y los maestros» (Suarez, 2007, p. 28. Revista No. 77). 
Superado ya el efecto de fragmentación que produce el discurso hegemónico, los maestros encontraron una nueva posibilidad de pensarse y de proyectar la naturaleza de su oficio, la cual quedó plasmada en tres grandes principios recogidos en las conclusiones del XII congreso de FECODE:

1. El maestro como trabajador de la cultura, con compromisos pedagógicos que necesita rescatar para colocarlos al servicio de las masas populares y con una práctica pedagógica que contribuya a la liberación nacional, que desarrolle en el estudiante el espíritu creador, investigativo, crítico. Un maestro que aprenda junto a sus estudiantes, que no domestique, que no reprima, que sepa luchar por la libertad, pero también enseñe a ser libres, en fin, que incorpore lo mejor de las experiencias nacionales y universales a su práctica docente.

2. El maestro como luchador consecuente por sus derechos laborales y salariales.

3. El maestro como ciudadano, luchador por sus derechos democráticos y políticos, participante efectivo en la lucha por reivindicaciones populares, entre ellas, las del campo educativo. Solidarios con las luchas de todos los trabajadores, y el pueblo colombiano.

(Conclusiones XII congreso de FECODE, Revista No. 1).

Estos principios orientadores del MP constituyen un contradiscurso, entendido ya no como simple deslizamiento doxático, sino como ruptura epistémica; es decir, una forma «otra» de pensar el discurso hegemónico y liberarse de su poder centrador. Esta ruptura tiene que ver «con la forma en que definió una concepción sobre el maestro y erigió una triple dimensión que precisaba los horizontes y el sentido de su quehacer, su función y su papel: la concepción del maestro como trabajador, intelectual y ciudadano» (Editorial, Revista No. 77).

En efecto, dicha concepción trae consigo ingredientes que no aparecían antes en el discurso de los maestros ni sobre los maestros. Se trata de autoproclamarse como trabajador de la cultura, con compromisos pedagógicos, con una práctica pedagógica que contribuya a la liberación nacional, que aprenda junto a sus estudiantes, que no domestique, que no reprima, que luche por la libertad mientras enseña a otros a ser libres. Cada una de estas tesis implica transformaciones sustanciales de los conceptos de educación, de maestro y de escuela, que no estaban en el discurso hegemónico, en el cual, históricamente, se lo había representado como un sujeto heterónomo y marginal, como se describe en el apartado 2 de este trabajo.

Se resitúan allí la naturaleza emancipadora de las prácticas pedagógicas, la educación como ejercicio para la libertad (tesis en la que resuena el ideario freiriano), el espíritu autocrítico del maestro que reconoce que 
no puede pretender luchar por la libertad cuando sus acciones reprimen y domestican a sus estudiantes; reconoce igualmente que debe aprender con sus estudiantes, es decir, que debe revisar sus propios aprendizajes y transformarlos.

En el mismo sentido, "proclamarse ciudadano luchador por su derechos democráticos y políticos», es una nueva forma de representarse como sujeto político que tampoco figuraba en el discurso de la hegemonía. A partir de esta tesis, el magisterio empieza a reclamar su derecho de participar en política: no simplemente de elegir, sino de ser elegido, condición esta que históricamente le había sido negada.

Estas premisas y sus realizaciones prácticas, construyeron una representación del MP «(...) como poder, como contrapoder, o sea todo lo que pueden los maestros; en ese movimiento los mismos maestros se preguntaron todo lo que sabían y todo lo que podían hacer» (Martínez Boom, 2007, p. 25. Revista No. 77).

Estas razones refuerzan la tesis que se quiere sostener en este apartado, en el sentido de que el MP constituyó una verdadera forma de contradiscurso, una alternativa contra hegemónica, liberada del recurso a la réplica y de lo puramente contestatario.

\section{El discurso de los fundamentos del MP}

Estas elaboraciones discursivas tenían una base teórica construida en la discusión entre intelectuales y maestros, en las que se reconocieron los límites y las posibilidades del MP, la necesidad de una teoría fuerte y un redimensionamiento de las acciones prácticas que no podían quedarse en la simple lucha reivindicativa. Veamos algunas de estas consideraciones que aparecen en la presentación de los fundamentos y propósitos del MP:

La indiferencia teórica asumida consciente e inconscientemente y la ausencia de un ideario pedagógico autónomo y coherentemente desarrollado son problemas que deben ser resueltos. ¿Por qué renunciar a nuestro derecho de pensar con cabeza propia? ¿Es posible delegar en otros nuestra tarea crítica reflexiva? Un espíritu verdaderamente libre no puede ser sino aquel que conoce la realidad, comprende sus límites y sus posibilidades transformadoras. Aquí, la sentencia filosófica tiene plena validez: la libertad presupone el conocimiento de la necesidad

(Fundamentos y propósitos del Movimiento Pedagógico. Revista No. 1). 
Estos apartes de la presentación de los fundamentos del MP incorporan cierta retórica "crítica reflexiva» que presupone como posibilidad el derecho a pensarse a sí mismo, la necesidad de teorizar la realidad, la imposibilidad de delegar en otros la tarea de reflexionar, etc., que habrían de actuar como mecanismos aglutinadores de las voluntades dispersas:

Se trata de conformar una corriente de ideas y de intentos prácticos, de modo que muy pronto se manifieste una presencia fuerte de las iniciativas de nosotros, los educadores, en el campo educativo. Aglutinar y elaborar las preocupaciones profesionales del magisterio y sus esfuerzos aislados: en esto consiste el Movimiento Pedagógico. La imposibilidad de un control total de nuestro trabajo hace que tengamos la posibilidad hasta cierto punto de ser jueces y orientadores de nuestro quehacer. De ello se derivan responsabilidades históricas que debemos explicar y asumir. Es mucho lo que podemos y lo que debemos hacer en el campo de la cultura (Fundamentos y propósitos. Nuestro quehacer. Revista No. 1).

Ideas como la "presencia fuerte de las iniciativas de nosotros los maestros», "aglutinar y elaborar preocupaciones profesionales del magisterio», "ser jueces y orientadores de nuestra quehacer», "es mucho lo que podemos y debemos hacer en el campo de la cultura", construyen representaciones positivas del magisterio, descentradas de la simple confrontación con la hegemonía. El discurso deja de ser contestario, se torna propositivo y se inviste de una retórica particular que no replica, sino que propone el protagonismo de los maestros, que convoca la posibilidad y el deber como condiciones de su quehacer. En ello se configuran los elementos del contradiscurso positivamente construidos, ideológicamente distanciados de las representaciones hegemónicas.

De otra naturaleza es la discusión histórica de los alcances de este discurso, pues si se miran los autores de los artículos de la revista Educación y Cultura, parece que la pregunta retórica de si ¿Es posible delegar en otros nuestra tarea crítica reflexiva? se hubiese resuelto afirmativamente, pues los nombres de los intelectuales que acompañaron el Movimiento Pedagógico en sus orígenes, aquellos que contribuyeron a dotarlo de bases teóricas y epistemológicas genuinas, se repiten una y otra vez como autores de los artículos. De alguna manera el discurso de la revista Educación y Cultura produce su propia hegemonía, manifiesta en quién dice y qué reconocimiento se le otorga en sus páginas. Son muy pocas las voces de los maestros de las bases exhibidas en la revista. Quizá haya que pensar que están negadas por esa condición históricamente determinada de sus evidentes dificultades para hacer uso de la escritura (que paradójicamente enseñan) y no porque 
la hegemonía omnipresente determina quiénes dicen y cuáles son las condiciones discursivas de ese decir en las páginas de la revista.

Las dificultades del grueso de los maestros con la escritura como práctica discursiva hegemónica quizá hayan contribuido a que su discurso, de naturaleza sustancialmente oral, se mantenga invisibilizado y no haya alcanzado las páginas de la revista. Con esta consideración, un poco hipotética, es posible pensar, entonces, que los maestros continúan siendo discursivizados, procesados por otros, que, como se afirma en el apartado 2, su figura y sus acciones aún se constituyan en un discurso de otros discursos.

\section{A manera de conclusiones}

La producción discursiva de los maestros, representada en la revista Educación y Cultura, está orientada al debate político más que a los temas propiamente educativos y pedagógicos. Un porcentaje superior al $60 \%$ de los artículos analizados se dedican a debatir y/o confrontar el contenido de las políticas educativas. Distintos investigadores señalan que esta tendencia se debe a que la incursión de la políticas neoliberales «obligaron» a FECODE -y particularmente al CEID (Centro de Estudios e Investigación Docente), responsable de la revista Educación y Cultura- a privilegiar el debate político para mantener la estructura y poder de convocatoria del gremio frente a la arremetida neoliberal. Sin embargo esta «elección» privó al magisterio de generar un tipo de resistencia distinto a la réplica, y terminó por desdibujar el impacto transformador del Movimiento Pedagógico.

El conflicto entre Estado y gremio de los maestros es de naturaleza socioeconómica. El asunto que más se despliega en la revista Educación y Cultura es el análisis y cuestionamiento de las políticas educativas. No obstante la importancia de este debate y la denuncia de los efectos de las políticas educativas en la educación pública, no hay en este tipo de textos ninguna posibilidad de romper el «cerco discursivo» que impone la hegemonía, pues la fuerza centradora del discurso hegemónico hace que el contradiscurso se vuelva recesivo y produzca un efecto contrario al que pretende rebatir: la actualización, naturalización y sedimentación en el discurso social, del discurso hegemónico.

Desde la teoría del contradiscurso es posible diferenciar entre discursos que generan ruptura epistémica, verdaderas formas discursivas contrahegemónicas y discursos doxáticos o «deslizamientos» de la hegemonía. Estos casos de deslizamiento producen efectos de sedimentación de la hegemonía y son la condición predominante del contradiscurso en los maestros, 
pues la réplica y el espíritu contestatario impiden descentrarse de las representaciones que instaura el discurso hegemónico.

El contradiscurso o discurso de resistencia tiene manifestaciones distintas en el discurso de los maestros. En algunos casos se convierte en simple réplica que pretende reivindicar los derechos salariales y sindicales, sin ningún elemento propositivo alterno. Esto ha contribuido a reforzar una imagen social negativa de los maestros y a que el discurso hegemónico los señale públicamente como «el problema» de la educación.

El Movimiento Pedagógico MP no solo se constituyó en la plataforma pedagógico-política que legitimó la emergencia del discurso sobre maestro intelectual, sino que, además, hizo visible un discurso contra el poder hegemónico del Estado y aún contra el dogmatismo partidista de la izquierda, que no comprendía «que una organización sindical como FECODE considerara importante el fortalecimiento pedagógico». Es posible, en consecuencia, sostener que el Movimiento Pedagógico constituye una verdadera expresión de contradiscurso como valoración positiva de la resistencia. Es un discurso instituyente de unas nuevas representaciones del maestro como sujeto político, como intelectual y como trabajador de la cultura, que desencadenó transformaciones sustanciales en las prácticas pedagógicas y en las formas de auto-representarse de los maestros.

En la revista Educación y Cultura -como órgano de comunicación del MP- se pone de manifiesto que a pesar de su proclama de ser el órgano de expresión del magisterio, éste continúa siendo procesado por otros, pues son escasas las voces de los maestros de base que alcanzan sus páginas. Este fenómeno muestra cómo, desde las tesis de Angenot, la hegemonía discursiva continúa operando aún entre los discursos de resistencia o que discuten el discurso hegemónico. Así las cosas, los artículos de la revista representan mejor las ideas de los intelectuales e investigadores que han acompañado desde sus orígenes el MP. Puede decirse que a lo largo de sus 25 años, Educación y Cultura ha mantenido un grupo más o menos estable de colaboradores, que desde sus orígenes escriben en torno a la educación y los maestros.

El maestro aparece en el plano discursivo como discurso subsidiario de otros más amplios que los contienen (pedagogía, educación, política, etc.), y que en la necesidad de legitimarse, legitiman de paso la figura del maestro en función de su propio objeto discursivo. No existe, en consecuencia, una imagen del maestro que no se corresponda, de alguna manera, con las elaboraciones discursivas construidas, por ejemplo, en la teoría pedagógica, la sociología y/o la psicología educativas. 


\section{REFERENCIAS}

Álvarez, A. (2006). El estatuto del maestro hoy. Aportes para la discusión sobre la creación de un instituto nacional de pedagogía. En: Territorios pedagógicos: Espacios, saberes y sujetos. Bogotá: Editorial UPN.

Álvarez, A. (1996). ¿La feria del crédito: ha dejado de existir? En: Educación y Cultura 42, pp. 5-9.

Álvarez, A. (1991). Maestro, historia de un oficio. En: Revista Colombiana de Educación 22-23, pp.140-159.

Amaya, G. (1996). La formación permanente de docentes: Un proyecto que debemos pensar y construir. En: Educación y cultura 42, pp. 10-16.

Angenot, M. (1989). Hégémonie, dissidence et contre-discours: réflexions sur les périphéries du discours social. En: Études littéraires (22) 2, pp. 11-24. Disponible en: http://www.erudit.org/revue/etudlitt/1989/v22/n2/500895ar.html

Angenot, M. (1998). Interdiscursividades. De hegemonías y disidencias. Córdoba: Universidad Nacional de Córdoba.

Angenot, M. (2010). El discurso social. Los límites históricos de lo pensable y lo decible. Buenos Aires: Siglo xxı Editores.

Baccarat, M. y Graziano, N. (2001). ¿Sabemos de qué hablamos cuando usamos el término competencias? En: Educación y Cultura 58, pp. 48-56.

Ballanti, G. (1979). El comportamiento docente. Buenos Aires: Kapelusz.

Bajtin, M. (1992). Construcción de la enunciación. En: A. Silvestre y G. Blanck. Bajtín y Vigotski: la organización semiótica de la conciencia, pp. 245-276. Barcelona: Anthropos..

Banco Mundial (1996). Prioridades y estrategias para la educación. Estudio sectorial del Banco Mundial. Washington.

Bogoya, D. (2000). Competencias y proyecto pedagógico. Bogotá: Unibiblos.

Bustamante, G. (2001). Sobre un intento retórico de legitimar la evaluación de «Competencias básicas». En: Pedagogía y saberes 16. Bogotá: UPN.

Carbonell, J. y Tort, A. (2006). La educación y su representación en los medios. Madrid: Morata.

Charaudeau, P. (1983). Langage et discours. Paris: Hachette. 
Delors, J. (1996). La educación encierra un tesoro. Unesco. Disponible en: http:// www.unesco.org/education/pdf/DELORS_S.PDF

De Tezanos, A. (2006). El maestro y su formación: Tras las huellas y los imaginarios. Bogotá: Cooperativa Editorial Magisterio.

De Tezanos, A. (1985). Maestros: Artesanos intelectuales. Bogotá: UPN, CIID.

FeCOde (2008). Iniciado el nuevo siglo, continúa la muerte y el hostigamiento al magisterio Colombiano. En: El educador colombiano. Boletín 08. Disponible en: www.fecode.edu.co/descargas/educadorcol/boletin_ec_n8.pdf). Consultado en: junio 22 de 2008.

Foucault, M. (2005). El sujeto y el poder. En: J. Toro (Comp.). Pensamiento y experimentación, pp. 31-52. Bogotá: Editorial archipiélago.

Gee, J. P. (2005). La ideología en los discursos. Madrid: Morata.

Gramsci, A. (1975). Los intelectuales y la organización de la cultura. México: Juan Pablos, Editor.

Gramsci, A. (1979). Sobre el fascismo. México: Editorial ERA.

Herrera, M. y Low, C. (1994). Los intelectuales y le despertar cultural del siglo. El caso de la escuela Normal Superior. Una historia reciente y olvidada. Bogotá: Editorial UPN.

Martínez, A.; Castro, O. y Noguera, C. (1989). Crónica del desarraigo. Bogotá: Editorial Magisterio.

Martín Rojo, L. y Van Dijk, T. (1998). Había un problema y se ha solucionado: La legitimación de la expulsión de inmigrantes 'ilegales' en el discurso parlamentario español. En: L. Martín Rojo y R. Whittaker. Poder-decir o el poder de los discursos, pp. 169-234. Madrid: Arrecife.

Not, L. (1989). Las pedagogías del conocimiento. México: Fondo de Cultura Económico.

Puryear, J. (1997). Corrientes de reforma educativa en América Latina. Caracas: PDVSA CIED.

Ratinoff, L. (1994) Las retóricas educativas en América Latina: la experiencia de este siglo. En: Boletín 35, diciembre, 1994, Proyecto principal de educación.

Rodrigo, M. (1989). La construcción de la noticia. Barcelona: Paidós. 
Shulman, L. (1989). Paradigmas y programa en el estudio de la enseñanza. Una perspectiva contemporánea. En: La investigación de la enseñanza (1). Barcelona: Paidós.

Serna, A. (2004). Del pedagogo y el político. Bogotá: Centro de investigaciones, Universidad Distrital Francisco José de Caldas.

Soler Castillo, S. (2009). Racismo y discurso en los textos escolares. Representación de la diversidad étnica y racial en los textos de ciencias sociales en Colombia. En: Nina S. de Friedemann: cronista de disidencias y resistencias. Bogotá: CES.

Tedesco, J. y Tenti, E. (2002). Nuevos tiempos y nuevos docentes. Buenos Aires: Unesco. Disponible en: http://ipes.anep.edu.uy/documentos/noticias_portada/ vinculo_abajo/dir_ces/pedagogica/tedesco.pdf

Torres, R. M. (2000). Reformadores y docentes: el cambio educativo atrapado entre dos lógicas. En: A. L. Cárdenas, A. Rodríguez Céspedes y R. M. Torres. El maestro protagonista del cambio educativo. Bogotá: CAB/EDITORIAL MAGISTERIO.

Torres, R. M. (2004). Nuevo rol docente: ¿qué modelo de formación, para qué modelo educativo?. En: Revista Colombiana de Educación, 47. Bogotá: UPN.

Van Dijk, T. A. (1995). De la gramática del texto al análisis crítico del discurso. En: Beliar (Boletín de Estudios Lingüísticos Argentinos), Año 02, Número 06.

Van Dijk, T. A. (1990). La noticia como discurso. Comprensión, estructura y producción de la información. Barcelona: Paidós.

Van Dijk, T. A. (1999). El análisis crítico del discurso. En: Revista Antropos, 186.

Van Dijk, T. A. (1998) Ideología. Una aproximación multidisciplinaria. Barcelona: Gedisa.

Van Dijk, T. A. (1996). Análisis del discurso ideológico. Disponible en: http://segundaslenguaseinmigracion.com/L2ycomptext/Anlisisideolgico.pdf

Van Dijk, T. A. (2004). Discurso y dominación. Grandes conferencias en la facultad de ciencias humanas. Bogotá: Universidad Nacional de Colombia.

Van Leeuwen, T. (1996). The representation of social actors. En: C. CaldasCoulthard y M. Coulthard (Eds.). Text and Practices: Readings in critical discourse analysis. London: Routledge. 
Vasilachis de Gialdino, I. (1998). La construcción de representaciones sociales. Discurso político y prensa escrita. Un análisis sociológico, jurídico y lingüístico. Barcelona: Gedisa.

Wodak, R. y Meyer, M. (2003). Métodos de análisis crítico del discurso. Barcelona: Gedisa.

Zuloaga, O. (1999). Pedagogía e historia: la historicidad de la pedagogía. La enseñanza un objeto de saber. Medellín: Editorial Universidad de Antioquia. 


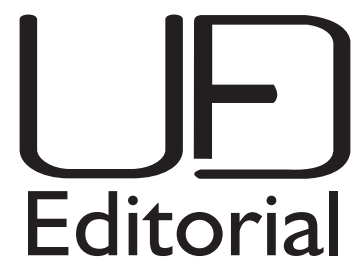

Este libro fue compuesto en caracteres

Optima y Trebuchet MS.

Impreso en el mes de enero de 2014

en los talleres de Javegraf.

Bogotá, Colombia. 2014

Soler Castillo, Sandra Teresa / Baquero Másmela, Pedro Maestros, hegemonía y contradiscurso / Sandra Teresa Soler Castillo, Pedro Baquero Másmela. -- Bogotá : Universidad Distrital Francisco José de Caldas, 2013.

165 p. ; $24 \mathrm{~cm}$.

ISBN 978-958-8832-23-4 / ISBN digital: 978-958-8832-29-6

1. Educación superior 2. Pedagogía - Análisis del discurso

3. Maestros - Comunicación 4. Sociología de la educación

I. Baquero Masmela, Pedro, 1961- II. Tít.

378.17 cd 21 ed.

A1423445

CEP-Banco de la República-Biblioteca Luis Ángel Arango 


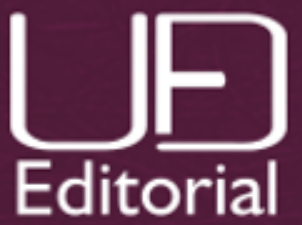

En Maestros, hegemonía y contradiscurso se recoge el fruto de dos investigaciones realizadas en torno a la figura y representaciones del maestro del sector público en Colombia, las cuales aunque estrechamente vinculadas por su campo temático y línea de investigación, situadas justamente en los estudios del discurso y la educación, difieren, sin embargo, en cuanto a los objetos de estudio y perspectivas analíticas que eligieron para abordar la pregunta por las representaciones del maestro y su movilización en la producción discursiva de actores sociales específicos: mientras una se ocupa del estudio de las representaciones del maestro y sus acciones en los medios de comunicación, la otra se centra en desarrollar y aplicar el concepto de contradiscurso al análisis de las propias elaboraciones discursivas de los maestros, desde las cuales han resistido y/o legitimado el discurso oficial hegemónico sobre ellos mismos como actores sociales.

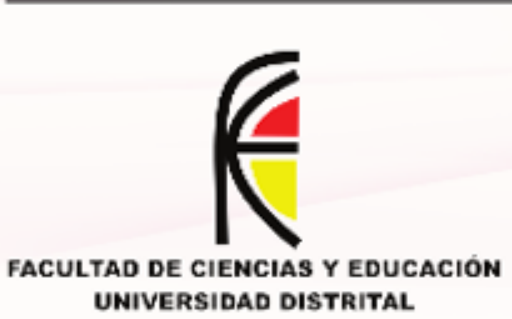

